\title{
RADZIECKA ADMINISTRACJA WOJSKOWA NA PÓŁNOCNO-WSCHODNICH ZIEMIACH POLSKI I SCENARIUSZE ICH ANEKSJI W RADZIECKICH DOKUMENTACH (wrzesień - grudzień 1939 r.)
}

Problem wydarzeń z 17 września 1939 r., tj. agresji ZSRR na Polskę, należy do kwestii kontrowersyjnych, budzących wiele emocji, obrosłych w liczne zafałszowania i mity. Przez ponad 50 lat radziecka historiografia, a w ślad za nią i historiografia PRL, usprawiedliwiały agresję, przypisując Armii Czerwonej „misję wyzwoleńczą” i uzasadniając działania agresora troską o dobro miejscowej ludności, nie tylko białoruskiej i ukraińskiej, lecz również polskiej. Historycy zamiast rzeczywistych dokumentów otrzymywali agitki propagandowe i zafałszowane oficjalne dokumenty spreparowane dla potrzeb bieżącej polityki i propagandy. W ten sposób ukształtowano nieprawdziwy, wręcz żałosny obraz wydarzeń 17 września prezentowany w oficjalnej radzieckiej historiografii. W 1986 r. zapoznałem się z wydaną w ZSRR literaturą na ten temat, obejmującą ponad 300 opracowań. Wszystkie te prace, niezależnie od tytułów naukowych ich autorów (byli wśród nich profesorowie i akademicy) nie wykraczały poza tezy artykułu wstępnego „Prawdy” z 17 września 1939 r., tj. oficjalnego stanowiska władz ZSRR.

Dopiero po rozpadzie ZSRR do rąk historyków zaczęły trafiać dokumenty z zespołów specjalnych radzieckich archiwów, z których wynika jednoznacznie, że 17 września 1939 r. dokonano wcześniej zaplanowanej i skrupulatnie przeprowadzonej agresji przeciwko Polsce i Polakom. Potwierdził to m.in. J. Stalin 7 września 1939 r. w rozmowie z G. Dymitrowem. Omawiając stanowisko międzynarodowego ruchu komunistycznego wobec najazdu Niemiec na Polskę stwierdził: „W obecnej sytuacji zlikwidowanie tego państwa (tj. Polski) oznacza tylko tyle, że ubędzie jeszcze jedno burżuazyjne, faszystowskie państwo! Co złego w tym, że w wyniku zlikwidowania Polski, rozszerzymy system socjalistyczny na nowe obszary i ludność"'.

A zatem chodziło o opanowanie nowych terenów i objęcie radzieckim systemem ludności zamieszkującej na wschodnich ziemiach Polski. Agresję zaplanowano i dokonano jej w zmowie z hitlerowskimi Niemcami, z którymi Polska prowadziła od 1 września 1939 r. wojnę obronną. Wiele świadczy o tym, że był to również odwet na Polsce i Polakach za zatrzymanie w 1920 r,. radzieckiego pochodu na zachód i przegraną wojnę. Za kulisami wydarzeń 17 wrze-

\footnotetext{
'Komintern i wtoraja mirowaja wojna, czast' 1, do 22 ijunia 1941 g., Moskwa 1994, s. 11.
} 
śnia o odwecie mówiono dosyć często, jednak w oficjalnych dokumentach i propagandzie tego aspektu nie eksponowano.

Po rozdziale Polski między Niemcy i ZSRR i wspólnym stwierdzeniu Hitlera i Stalina, że Polska nie powinna już nigdy odrodzić się w kształcie określonym Traktatem Wersalskim, tj. jako państwo niepodległe w ustalonych wówczas granicach, ZSRR przystąpił do zagospodarowania „swojej” części zagarniętego terytorium. Już po wejściu na polskie ziemie 25 września 1939 r., Stalin zaproponował Niemcom zmiany w przebiegu linii podziału Polski. W celu uwiarygodnienia propagandowego agresji hasłami obrony i opieki nad swoimi białoruskimi i ukraińskimi „braćmi jednej krwi” ZSRR zaproponował rezygnację na rzecz Niemiec z ziem leżących między Bugiem i Wisłą, w zamian za wpływy na Litwie, która w dotychczasowych porozumieniach była w strefie wpływów Niemiec. Niemcy zgodzili się na te zmiany, co formalnie uregulowano w podpisanym w Moskwie 28 września 1939 r. traktacie o granicach i przyjaźni. Potwierdzono też óstatecznie charakter podziału Polski i określono zakres wspólnych działań Niemiec i ZSRR w zwalczaniu polskich dążeń niepodległościowych.

Po korekcie linii podziału ziem polskich ZSRR eksponuje kwestie narodowościowe i antypolskie w celu spotęgowania białoruskiego i ukraińskiego nacjonalizmu i szowinizmu oraz wywołania chęci połączenia się z macierzystymi republikami i wejścia w skład państwa radzieckiego. Służyć temu miało też rozbudzanie potrzeby „wyzwolenia społecznego” i rewindykacji praw najuboższych. ZSRR zabiegał na zajętych ziemiach o poparcie ludzi biednych i czujących się skrzywdzonymi, m.in. dlatego obiecywał im nie tylko „równouprawnienie” i dostęp do wszystkich dóbr, lecz również wyrównanie krzywd. Wskazywał na „polskich panów” jako winnych ich krzywd i niedoli.

Po rezygnacji z ziem polskich, leżących między Bugiem i Wisłą, uznano, że pozostałe ziemie polskie są ziemiami Zachodniej Białorusi i Zachodniej Ukrainy, a zamieszkujący na nich Białorusini i Ukraińcy „mają święte prawo” do samostanowienia odmawianego im przez „pańską Polskę”. ZSRR teraz spełnia tylko ich „marzenia o zjednoczeniu”. Polaków natomiast uznano na tych ziemiach za „kolonizatorów” lub spolonizowanych Białorusinów i Ukraińców. „Kolonizatorów” zadecydowano wyeliminować z tych ziem, a „spolonizowanym” dać szanse pod warunkiem, że wyrzekną się polskości i potępią państwo polskie, tj. zgodzą się na pełną sowietyzację i rusyfikację.

W tak ukształtoweanej atmosferze rozpoczęto przygotowania do wyborów zgromadzeń ludowych przewidzianych w Dyrektywie Rady Wojennej Frontu Białoruskiego (RW Fr.B) z 16 września 1939 r. (dok. 2) i Uchwale Biura Politycznego Wszechzwiązkowej Komunistycnzej Parii (bolszewików) (WKP(b)) z 1 października 1939 r. (dok. 6). 5 października 1939 r. Zarząd Tymczasowy (ZT) Białegostoku wystąpił z „oddolną” inicjatywą przeprowadzenia nakazanych wyborów do Zgromadzenia Ludowego Zachodniej Białorusi. Z podobną inicjatywą wyborów do Zgromadzenia Ludowego Zachodniej Ukrainy wystąpił ZT Lwowa ${ }^{2}$. Zrezygnowano natomiast z wyborów do określonego w Dyrektywie RW Fr.B. nr 1 Polskiego Zgromadzenia Ludowego, które miało proklamować Polską Republikę Związkową w składzie ZSRR z ziem wschodniego Mazowsza i Lubelszczyzny. Wybory do zgromadzeń ludowych przebiegały pod hasłami: konfiskaty ziem obszarniczych, nacjonalizacji przemysłu, kolei i banków, powołania władz radzieckich na zajętych terenach i włączenie ich w skład ZSRR.

${ }^{2}$ Przebieg wcielania ziem południowo-wschodnich przebiegał według tego samego scenariusza (por. A. Sudol, Początki sowietyzacji Kresów Wschodnich. Jesień 1939 roku, Bydgoszcz - Toruń 1997. 
W trakcie kampanii wyborczej do Zgromadzenia Ludowego Zachodniej Białorusi rozstrzygnięto też kwestię dalszej przynależności państwowej Wileńszczyzny. Zgodnie z podpisanym 10 października 1939 r. traktatem radziecko-litewskim Wilno i znaczna część Wileńszczyzny przekazane zostały Litwie. Ziemie te przed opuszczeniem zostały dokładnie ograbione ze wszelkich dóbr (dok. 26). Przejście Litwy do strefy wpływów ZSRR spowodowało, że i to państwo latem 1940 r. podzieliło los ziem wschodnich Polski.

Przygotowane i przeprowadzone w sytuacji stanu wojennego wybory do zgromadzeń ludowych przyniosły oczekiwane przez ZSRR wyniki. Obradujące w Białymstoku w dniach 28-30 października Zgromadzenie Ludowe Zachodniej Białorusi podjęło w stworzonej olbrzymim wysiłkiem atmosferze jednomyślności opracowane wcześniej uchwaly (deklaracje): o władzy państwowej, o konfiskacie ziemi obszarniczej, o nacjonalizacji banków i wielkiego przemysłu oraz o wejściu Zachodniej Białorusi w skład ZSRR. Wybrana przez zgromadzenie „pełnomocna delegacja" udała się następnie do Moskwy na specjalną sesję Rady Najwyższej ZSRR z prośbą o włączenie Zachodniej Białorusi w skład ZSRR. 2 listopada 1939 r. RN ZSRR specjalnym dekretem uwzględniła prośbę delegacji i zgromadzenia. 14 listopada 1939 r. uczyniła to również RN BSRR, do której wcielono północno-wschodnie ziemie Polski. W ten sposób na mocy przepisów radzieckiego prawa wewnętrznego polskie ziemie wschodnie znalazły się w granicach ZSRR jako integralna ich część. Zmianom tym nadano rangę konstytucyjną, wprowadzając uzupełnienia do konstytucji ZSRR, w której określono też nowy podział administracyjny zagarniętych ziem polskich.

Publikowane dokumenty obejmują okres od 15 września 1939 r. do 28 grudnia 1939 r. Data wyjściowa to okres zakończenia przygotowań do agresji na wschodnie ziemie Polski, a końcowa to zakończenie procedury „sankcjonowania” agresji przepisami prawa wewnętrznego ZSRR. Dokonany 17 września 1939 r. atak na Polskę doprowadził w ciągu 2 tygodni do zajęcia wschodnich ziem Polski. Na podbitych terenach rozpoczął się proces przygotowań do włączania tych ziem do ZSRR, który trwał do końca 1939 r. Publikowane dokumenty obrazują przebieg tego procesu, zawierają klarowny scenariusz radzieckiej agresji i prób usankcjonowania ${ }^{3}$, budowę i funkcjonowanie radzieckiej administracji wosjkowej, jak i bezpardonowy sposób zamiany systemu okupacji wojskowej w aneksję zajętych w wyniku agresji ziem polskich. Wskazują tèż na różne aspekty radzieckiej polityki na tych terenach.

Publikowane dokumenty jednoznacznie wskazują, że na zajętych przez ZSRR ziemiach wschodnich Polski „zastępowały rewolucję” i organizowały w jej imieniu nowy porządek trzy następujące siły:

1. Armia Czerwona i jej aparat polityczny,

2. grupy operacyjne NKWD wraz z siecią agenturalną,

3. aparat partyjny i oddelegowany do jego potrzeb aktyw występujący często też w mundurach.

P. Ponomarenko na naradzie przewodniczących zarządów tymczasowych w Wołkowysku 4 października 1939 r. stwierdził, że władze tymczasowe są władzami wojskowymi a nie rewolucyjnymi i że należy się tu osiedlać na stałe wraz z rodzinami, gdyż ziem tych nie opuścimy i naszego miejsca nie zajmą „wyzwoleni Bialorusini” (dok. 8).

\footnotetext{
${ }^{3}$ Dokumenty o przygotowaniach i przebiegu wyborów do Zgromadzenia Ludowego Zachodniej Biaforusi autor przygotowuje do opublikowania w odrębnej pracy.
} 
Nie ma natomiast w publikowanych dokumentach dostatecznych informacji o oporze społeczeństwa zajmowanych ziem wobec agresora, byłoby to bowiem sprzeczne z głoszonymi wówczas mitami o pełnym, spontanicznym poparciu ludności radzieckich władz i witania Armii Czerwonej kwiatami. Przygotowując dokumenty do publikacji autor zrezygnował z prostowania w przyspisach występujących ewidentnych kłamstw i jednostronnych ocen. W świetle obecnej wiedzy o tych wydarzeniach są one tak oczywiste, że nie wymagają takich zabiegów.

Dokumenty publikowane są w języku oryginału, tj. w języku rosyjskim w całości, za wyjątkiem dok. 1, który drukujemy w obszernych fragmentach. Skrótów dokonali autorzy zbioru, z którego ten dokument pochodzi ${ }^{4}$. Brak dostępu do archiwów NKWD (NKGB) nie pozwala na pełny druk na podstawie oryginału. Opuszczone fragmenty podaję za wydanym w Warszawie zbiorem dokumentów. ${ }^{5}$.

Większość dokumentów publikowna jest po raz pierwszy. Jedynie dokumenty 1, 2, 3, 4, 6, 7 i 10 były już w części lub całości publikowane. Ponieważ wydawnictwa, w których je opublikowano, są trudno dostępne, a są one istotne dla prezentowanej tematyki, autor zdecydował się na ich opublikowanie.

Dokumenty pochodzą ze zbiorów Narodowego Archiwum Republiki Białoruś (NARB) w Mińsku oraz z obwodowych archiwów: w Grodnie (Państwowe Archiwum Organizacji Społecznych Obwodu Grodzieńskiego - PAOSOG) i w Brześciu (Państwowe Archiwum Obwodu Brzeskiego - PAOB).

W dokumentach występują następujące mniej znane skróty:

б. - бывший

Белгиз - Белорусское госу,дарственное из,дательство

БОВО - Белорусский особ́ый военный округ

ч.челі. - человек

ДТО - Дорожно-транспортной отдел

ГУРКМ - Главное управление Рабоче-К рестьянской милиции

ИТJI - Исправительный трудовой лагерь

ИТК - Исправительная трудовая колония

к-р - контрреволюционный

ЛІКСМБ - Јенинский коммунистический союз молодежи Белоруссии

МТС - Машино-тракторная станция

Нарсудя - народньй судья

П/Р - политической работе

Райзо - Районный земельный отдел

Райздрав - Районный отдел здравохранения

PIКK - Районный исполнительный комитет

PКМ - Рабоче- крестьянская милиция

PK милиции - Районный комиссариат милиции

PKКА - Рабоче-крестьянская красная армия

с.г. - сегодня

УКОМ - Уез,дный комитет

Уисполком - Уездный исполнительный комитет.

${ }^{4}$ Organy Gosudarstwiennoj Biezopasnosti SSSR w Wielikoj Otieczestwiennoj Wojnie. Sbornik dokumientow, t. I, Nakanunie, Kniga pierwaja (nojabr 1938 g. - diekabr 1940 g.), Moskwa 1995, dok. 33.

"Zachodnia Białoruś", 17 IX 1939-22 VI 1941, Wydarzenia i losy ludzkie, rok 1939, Warszawa 1998, s. 71-74. 


\title{
DOKUMENTY
}

\section{Dokument 1}

1939 wrzesień 15. Moskwa - Fragmenty dyrektywy NKWD ZSRR okres'lajq̨cej zadania stużb bezpieczeństwa na ziemiach polskich po zajęciu przez Armię Czerwong

ИЗ ДИРЕКТИВЫ НКВД СССР

НАРДОНЫМ КОМИССАРИАТАМ ВНУТРЕННИХ ДЕЛ УССР И БССР ОБ ОРГАНИЗАЦИИ РАБОТЫ В ОСВОБОЖДЕННЫХ РАЙОНАХ ЗАПАДНЫХ ОБЛАСТЕЙ УКРАИНЫ И БЕЛОРУССИИ

\author{
15 сентября 1939 г. \\ $[\ldots]^{1}$
}

По продвижении наших войск и занятии тех или иных городов будут создаваться временные управления (временный орган власти), в состав которых войдут руководотели опергрупп НКВД.

Работники НКВД всіо свою работу должны проводить в теснейшем контакте с военным командованием и под руководством временных управлений. При выполнении специалных задач по обеспечениго порядка, пресечению подрывной работы и подавлению контрреволюции опергруппы НКВД по мере про,движения войсковых частей должны создавать на занятой территории во всех значительных городских пунктах аппарат НКВД за счет выделения из состава основной опергруппы НКВД небольших групп (численность в зависимости от важности конкретного пункта) с небольшим отря дом красноармейцев-пограничников. Выделенные опергруппы работников должны стать ядром будущих органов НКВД.

Опергруппы НКВД должны провести следугоие мероприятия:

1. Немедленно занять все учреждения связи: телеграф, телефон, радиостации и радиоузлы, почту, поставив во главе органов связи надежных ліодей.

2. Немедленно занять помещения государственных и частных банков, казначейств и всех хранилищ государственных и общественных ценностей и взять на учет все ценности, обеспечив их хранение.

3. Оказать всяческое содействие политотделам армии и прикомандированным к ним работникам в немедленном занятии типографии, редакций газет, складов бумаги и в налаживании изданий газет.

4. Немедленно занять все государственные архивы, в первую очередь архивы жандармерии и филиалов 2-го отдела генштаба (экспозитур, плящувок - органов разведки).

$$
[\ldots]^{2}
$$

6. Арестуйте наиболее реакционных представителей правительственных администраций (руководителей местной полиции, жандармерии, пограничной охраны и филиалов 2-го отдела генштаба, воевод и их ближайших помоцников), руководителей контрреволюоционных партий ${ }^{3}$.

7. Занять тюрьмы, проверить весь состав заключенных. Всех арестованных за революционную и прочую антиправительственную работу освободить, использовав эти мероприятия для... проведения политработы среди населения. Организовать новую 
тюремную администрацию из надежных людей во главе с одним из работников НКВД, обеспечив строгий режим содержания арестованных.

8. Одновременно с проводимыми операциами разверните следствие по делам заключенных участников контрреволюционных организаций с задачей вскрытия подпольных контрреволюционных организаций, групп и лиц, ставяццих целью проведение диверсий, террора, повстанчества и контрреволюционного саботажа. Лиц, изобличенных следствием в организации политических эксцессов и открытых контрреволюционных выступлений, арестовывать немедленно.

$$
[\ldots]^{4}
$$

10. ІПринять меры к выявлению и аресту агентов - провокаторов жандармерии, политической полиции и филиалов 2-го отдела генштаба, используя для этого изьятые архивы.

11. Обеспечить четкую организацию охраны обшественного порядка. Организовать надежную охрану электрических станций, водопроводов, продовольственных складов, элеваторов и хранилиш горючего. Организовать борьбу с грабежами, бандитизмом, спекуляцией. Организовать работу по противопожарной охране, назначунв начальниками пожарных команд надежных людей.

Провести регистрацию и изьятие у всего гражданского населения огнестрельного оружия (нарезного), взрыввецеест и радиопередатчиков.

$$
[\ldots]^{5}
$$

16. Конфискации фуража и продовольствия у населения избегайте. Необходимый фураж и продовольствие покупайте у населения за наличные в советских рублях, обья вив населению, что стоимость (курс) рубля равняется стоимости (курсу) злотого.

$$
[\ldots]^{6}
$$

Народный комиссар внутренных дел СССР

Берия

Źródło: Organy Gosudarstwiennoj Biezopasnosti SSSR w Wielikoj Otieczestwiennoj Wojnie. Sbornik dokumientow, t. I Nakanunie, Kniga pierwaja (nojabr 1938 g. - diekabr 1940 g.), Moskwa 1995, dok. 33.

a) Wielkie litery oryginału.

${ }^{1}$ Opuszczony fragment dyrektywy brzmi: „Zobowiązuję Was osobiście do zapoznania wszystkich kierowników grup NKWD z niniejszą dyrektywą i dokładnego poinstruowania razem z kierownikami grup NKWD. Zapoznać z dyrektywą także wszystkich pracowników operacyjnych grup NKWD i zapewnić skrupulatne wprowadzenie w życie niniejszej dyrektywy".

${ }^{2}$ Opuszczony 5 punkt dyrektywy brzmiał: ,W celu zapobieżenia spiskowej, zdradzieckiej działalności, aresztujcie znaczniejszych reprezentantów obszarników, książąt, szlachty oraz kapitalistów, ogłaszając, że są zakładnikami”.

${ }^{3}$ Dalszy ciąg tego punktu brzmiał: „PPS - Polskiej Partii Socjalistów, Stronnictwa Narodowego - partii narodowej, byłych partii narodowo-demokratycznych, Stronnictwa Pracy, Partii Chrześcijańsko-Demokratycznej, ONR. Powtarzam: ONR - Obóz Narodowo-Radykalny, organizacja polskiej młodzieży nacjonalistycznej. UNDO - Ukraińskie Zjednoczenie Narodowo-Demokratyczne. OUN - Organizacja Ukraińskich Nacjonalistów. USPR - Ukraińska Partia Socjalistyczno-Radykalna. FNJ - Front Jedności Narodowej. BNSO - Białoruska Organizacja Narodowo-Socjalistyczna. BNO - Białoruskie Zjednoczenie Narodowe (do 1934 r. nosiło nazwę Białoruskiej Chrześcijańskiej Demokracji). BRP - emigracyjna białogwardyjska organizacja mo- 
narchistyczna. ROWS - Rosyjski Wszechwojskowy Związek (emigracyjna białogwardyjska organizacja monarchistyczna). Na razie nie aresztować osob duchownych, zwłaszcza katolików”.

${ }^{4}$ Opuszczony 9 punkt dyrektywy brzmiał: „Przystąpicie do tworzenia sieci agenturalnoinformacyjnej, w pierwszym rzędzie ukierunkowanej na aparat państwowy, k-r kręgi burżuazyjno-obszarnicze i partie polityczne. Szczególną uwagę należy poświęcić szybkiej organizacji sieci informacyjnbej w redakcjach gazet, w instytucjach kulturalno-oświatowych, składach z żywnością, sztabach, gwardiach robotniczych i komitetach chłopskich".

${ }^{5} \mathrm{~W}$ opuszczonych $12-15$ punktach stwierdza się: „12. Konieczne jest aby grupy operacyjne NKWD zajęły pomieszczenia odpowiadające wymogom pracy NKWD. Dla trzymania aresztantów będących w śledztwie organizujcie więzienia wewnętrzne, zapewniające oich ochrobnę i obsługę. 13. Dla zapewnienia bezpieczeństwa i ciągłości pracy transportu kolejowego, pracownicy przewozowo-transportowowych grup NKWD zorganizują na każdej większej stacji działalność agenturalno-operacyjną do walki z dywersją, szpiegostwem i sabotażem k-r, prowadząc tę pracę pod kierownictwem naczelników grup operacyjnych NKWD. Wspólnie z komendantami i komisarzami stacji organizujcie ochronę dworców, parowozowni, warsztatów remontowych, magazynów dworcowych, pomp wodnych, mostów kolejowych, linii komunikacyjnych i łączności. 14. Pracownicy NKWD wezmą aktywny udział w przygotowaniu i realizacji (przez) zarządy tymczasowe zgromadzeń ludowych - ukraińskiego, białoruskiego i polskiego. Dla [zapewnienia] wzmożonych (warunków) bezpieczeństwa podczas zgromadzeń ludowych, zorganizować niezbędną działalność agenturalno-operacyjną w celu wykrycia i represjonowania organizacji k-r, grup i osób przeciwstawiających się i rozbijających organizację nowej władzy. 15. Wziąć aktywny udział w organizowaniu przez zarząd tymczasowy Gwardii Robotniczej i komitetów chłopskich, kładąc przy tym szczególny nacisk na zapobieganie przenikania do nich elementów k-r i prowokatorskich z wrogimi zamiarami”.

6 Opuszczony fragment 16 punktu brzmi: „Niniejsza dyrektywa nie podlega powieleniu i posiadają ją wyłącznie towarzysze: Mierkułow, Sierow, Boczkow i Canawa. Zapoznajcie (z nią) towarzyszy: Chruszczowa, Ponomarenkę, Timoszenkę i Kowalowa”. 


\section{Dokument 2}

1939 wrzesień 16, Smoleńsk - Dyrektywa nr 1 Rady Wojennej Frontu Bialoruskiego, określająca zasady powolywania przez armie wladz tymczasowych na zajmowanych polskich terenach.

Совершенно секретно ${ }^{\text {a) }}$ экз. Nr 226

\section{ПОСТАНОВЛЕНИЕ \\ ВОЕННОГО СОВЕТА БЕЛОРУССКОГО ФРОНТА 16 сентября 1939 № 01 г. Смоленск}

Западная Белоруссия и Западная Украина превращены правящими кругами IТольшши в бесправную колонию. Эти области с преобладающим Украинским и Белорусским населением являются объектами самого грубого грабежа и беззастенчивой эксплуатации со стороны польских панов-помециков.

Наша задача - положить конец угнетению трудяпихся Западной Украины и Западной Беларусси, помочь им освободиться от гнета помециков и капиталистов, представить полную безопасность трудяццимся этих областей, вместе с Великим Советским народом жить счастливой и радостной жизниго и иметь расцвет культуры и искусства.

В целях успешного разрешения этой великой исторической задачи по освобождениго трудящихся масс Западной Украины и Западной Белоруссии от помецичьекапиталистического гнета, разграбления и белого террора польских правителей, командование, политаппарат, партийные и комсомольские организации частей долюжны мобилизовать весь јтичный состав частей на выполнение боевого приказа Военного Совета на решительное победоносное наступление войск на всех участках фронта.

\section{ГІРЕДЛАГАЕТСЯ:}

1. Первое дело - с приходом наших войск и захватом тех или иных городов - создание

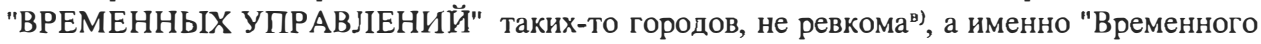
управления" такогото города из представителя Армии (в лице одного из политработников - он же председатель), представителя Наркомвнудела ${ }^{\text {c) }}$ и по одному представителю от рабочих и јевой интеллигенции.

2. Второе дело - организовать типографию, бумагу и поставить газету соответственно на украинском, белорусском и польском языках. Это дело политотделіов и прикомандированных к ним работников.

3. Третье дело - организация снабжения городского насселения продо-вольствием: захват складов про,цовольствия, привлечение к продовольственному делу снабжающих органов рабочих, установление тесной связи с рабочими организациами, соз,цание вооруженных рабочих гвардий для установления револтоционного порядка.

4. Четвертое дело - создать по гминам крестьянских комитетов из представителей бедноты и средняков для захвата помецичьих и монастырских земель бедноте и средня кам.

5. Никаких колтозов пока не строить и никаких призывов к устройству колхозов пока не делать.

6. Все эти мероприятия (1-4 пункты) имеют своей целыо разрушение существугоцей панско-буржуазной власти. Они долтжны проводиться политическими работниками 
Армии и работниками Наркомвнудела. Проводиться они должны от имении Армии, т.к. до создания новой власти единственной властьг в западных областях должны быть Армия и ее органы, действуюшие совместно с органами Наркомвнудела.

7. Для разрешения вопроса о характере новой власти и о способах создания новой власти должны быть сосваны после тцательной подготовки три народных собрания, на основе всеобших выборов: Украинское Народное Собрание - из выборных по областя м Западной Украины, Белорусское Народное Собрание - из выборных по областям Западной Белоруссии, Польское Народоное Собрание - из выборных по областям с преобладагшием болышинством польского населения.

Эти Народные Собрания должны:

а) утвердить захват помецичих земель крестьянскими комитетами;

б) репить вопрос о характере создаваемой власти, т.е. должна ли быть эта власть советской или другой;

в) решить вопрос о вхождение в состав СССР, т.е. о вхождении украинских областей в состав УССР, белорусских в БССР и вхождении польских областей в СССР в виде ІПольской Союзной Советской Республики.

8. Конфискации фуража и продовольствия у населения убегать.

9. Необходимые фураж и продовольствие покупать у населения за наличные в советских рублях, объявить населению что стоймость рубля (курс рубля) равен стоймости (курсу) злотого.

10. ІІироко разъяснить всему личному сосгаву частей историческое значение и важность поставленных задач. Не допускать никаких отступлений от настояцих указаний.

С получением этого постановления организовать тщательную подготовку политработннков дыя выполнения выпеуказанных ответственнейплих политических мероприя тий.

11. Особое внимание обрашаю на важность сисгематической информации, объективно освешающей дейсгвительное состояние частей.

Командуюший войсками

Белоруского фронта

командарм 2 ранга

КОВАЛЕВ

Член Военного Совета

Белорусского фронта

дивизионным комиссар

СМОКАЧЕВ

Член Военного Совета

Белорускофо фронта

корпусный комиссар

СУСАЙКОВ

Член Военного Совета

Белорускофо фронта

комдив ГУСЕВ

Член Военного Совета Белорусского

фронта

ПОНОМАРЕНКО

Na górze z lewej strony napis kancelaryjny 'Wpł. Nr 1'.

Oryginał, druk ulotny

PAOSOG w Grodnie, zesp. 9, spr. 33, t. 3, k. 2-3.

a) Podkreślenia i wielkie litery oryginału. Nr wpisany odręcznie czerwonym atramentem.

b) Komitety rewolucyjne, tworzone m.in. na zapleczu Armii Czerwonej w 1920 r.

c) Narodowy Komisariat Spraw Wewnętrznych (NKWD). 


\section{Dokument 3}

1939 wrzesień 19, Mińsk - Rozkaz dowódcy frontu Biatoruskiego w sprawie organizacji zarzq̨dów tymczasowych w Zachodniej Biatorusi

\section{IIPИKA3 \\ КОМАНДУЮЩЕГО ВОЙСКАМИ БЕЛОРУССКОГО ФРОНТА 19 сентября 1939 г., Минск}

1. Во всех городах на территории занятой частями Рабоче-Крестьянской Красной Армии, впред до образования органов власти создать "Временные Управления" из представителей Рабоче-Крестьянской Армии и местного населения, на которые возложить руководство административной, хозайственной и культурно-просветительной деательностыю в этих городах.

2. ГІриказываю Временным Управлениям немедленно привести в действие все предприя тия и заведения, призванные обслуживать население. Обязать владельцев немедленно открыть для нормальной работы: магазины, хлебопекарни, булочные, рестораны, парикмахерские, бани, кино-театры и т. д.

Востановить нормальную работу внутренней телефонной сети, почты, электроосвешения и водоснабжения.

3. Устанавливаю хождение на всей территории, занятой частями Рабоче-Крестьянской Красной Армии, советских денежных знаков и злотых. При этом стоимость одного злотого (курс слотого) равняется стоимости (курсу) одного рубля, т.е. один злотый равен о,цному рублю.

4. ГІризываю население занятых городов, местечек, сел и деревень к борьбе со вся кими нарушителями обшественного порядка. ГІредупреждаю, что лица, которье будут замечены в покушениях на телеграф, телефон, железные дороги, предприятия обшественного значения, лица ,допустившие хранение оружия по истечению 24 часов после опубликования приказа начальника гарнизона о сдаче оружия - будут привлекаться к строжайшей ответственносги.

ІПризываю всех граждан охранять революционный порядок, не ,допускать и пресекать враждебные наро,ду действия и выступления представителей и агентов помецицье капиталистических кругов бывшего польского государства.

5. ГІризываю население к оказанию помоци Временным Управлениям в ремонте дорог, мостов и всяких ,других сооружений, и к оказаниго всяческой помоци и содействия Временным Управлениям в проведении замеченных ими мероприятий.

Выражаю уверенность в том, что население занятых частями Рабоче-Крестьянской Красной Армии городов, местечек, сел и деревень окажет активнейшее содействие Временным Управлениям и частям Рабоче-Крестьянской Красной Армии в осушествлении ими исторической задачи освобождения трудяцихся от кабалы польских помещиков и капиталистов.

Коман,дуюшиий Войсками Белорусского Фронта Командрм 2-го ранга М. КОВАЛЕВ

Oryginał, druk ulotny.

Źródło: Państwowe Archiwum Obwodu Brzeskiego w Brześciu, zesp. 292, spr. 1, t. 1, k. 1. a) Wielkie litery oryginału. 


\section{Dokument 4}

1939 wrzesień 25, Minsk - Informacja P. K. Ponomarenki dla J, Stalina o sytuacji na pótnocno - wschodnich ziemiach Polski po wejściu Armii Czerwonej

\section{MOСКВА, ЦК ВКП(б) товарищу СТАЛИНУ И.В.а)}

По всем городам созданы Временные Управления, которые пристыупили к работе. Приступило к работе 30 редакции газет. Засылаются каждый день 100 тысяц экземпляров центральных и белорусских газет.

Повсеместно организованы крестьянские комитеты, приступивше к разделу помешичьей земли. Многих осадников и помешиков крестьяне истребляяот (веппают, расстреливают, убивают) или приводят и сдают Временным Управлениям.

Так как первые эшелоны наших войск действовали главным образом рейдовым поря дком и нигде не задерживались, а вторые эпелоны также движутся не пироким фронтом, а пाо магистралям, поэтому есть громадное количество сел и деревень, где еше красноармейцы и политработники не побывали. Благодаря этому обстоятельству у Временных Управлений в городах каждый день громадное количество ходоков от ${ }^{\text {) }}$ крестьянских комитетов или от крестьян, с самыми разнообразными вопросами: как делить помешичыю земліо, как организовать комитет, что делать с хлебом, который имеется в помецичьем имении, с имушеством, со скотом, что делать с хлебом, лежашим по складам и мельницам, который был поляками изъят у населения для армии, по расчету 8 килограмм с гектара.

Сейчас для работы по направлению деятельности крестьянских комитетов, во Временные Управления направлено 400 чел. толковых работников, из расчета 2 человека на 2 гмины (работать будут парами). Эти люди побывают везде, во всех деревнях. Задача их не командовать крестьянскими комитетами, а направлять их деятельность, советовать и т.д.

2. Появляется и регистрируется болышое количество людей, объявляюшцих себя коммунистами-подполыниками и партийными работниками. В дер. Подстаринка, Барановичского уезда, собралось 12 чел. таких коммунистов, об'явили себя комитетом деревни, не советуясь с крестьянами, и стали командовать. В Барановичах появились два "члена ЦК коммунистической партии Западной Белорусси" - Райский и Штирер. Они помимо Временного Управления попытались развернуть организационнуго работу - сбор оруљкия, производство обысков. Райский в рассылаемых записках называл себя председателем Революционного Военного комитета. При чем оба заяавляют представителю Временного Управления, что представители Красной Армии либеральничают 3 хозайчиками, малю забирагот, даже некоторых выпускают. Требуют болыше репрессий. Создается вгечатление о том, что они или хотят мстить, или провокаторы. В Новогрудке ко мне явились три человека и объявили, что они секретари районных комитетов партии гор. Новогрудка. Всех этих лиц берем на учет, от общественной работы не отталкиваем ${ }^{\text {c) }}$ и тпдательно проверяем.

ГІовсеместно громадный напор со стороны молодежы на Временные Управления с требованием организации комсомола. Организация комсомола сейчас принеслабы огромную пользу. Однако, есть некоторые опасения, что, организовавинись молодеж, комсомольцы, огромной активностью подавят деятельность крестьянских комитетов. Сейчас подготовливаем 400-500 чел. комсомольцев ,для работы в Западной Белоруссии, после Вашего разрешения приступить к организации комсомола.

Хочу поделиться некоторыми впечатлениями от своих поездок в Западную Бело- 
руссию. Мне пришлось посетить Столбцы, Мир, Тур, Кареличи, Новогрудок, Несвиж, Слоним, Барановичи, Волковыск и много сел и деревень. Белорусский крестьянинбедняк, часто и середняк, гол и раздет. Сахара в деревнях никогда не покупали, несмотря на кажуцуюся дешевизну - полтора злотых килограмм. Белорусское крестья нство настроено прекрасно, поддержкивает всем чем может Краснуго Армиго. Во всех этих городах, в которых пришлось побывать, я не встретил ни одного человека, которыйбы не владел русским языком. ГІрекрасно все говорят по русски, даже молодежь. Крестьяне говорят на настоянем белорусском языке, при чем, употреблягот много слов. о которых нас здесь уверяли, что они напдемовские, выдуманные. Напдемы могли выдумать в литературе, а народу привить не моглі, тем более западным белоруссам.

$3 \mathrm{a}^{\mathrm{d})}$ Белосток население встречает наши войска более сдержанно, русский язык знают меныне, чаше раздаются выстрелы из-за угла, из лесу по красноармейцам, командирам. В этих городах имеется ППС и рабочие пепеэсовцы - обстановка становится сложнее чем в местностях где белоруссы.

Между прочим, нужно сказать, что среди населения ГІолыни, и даже у евреев,

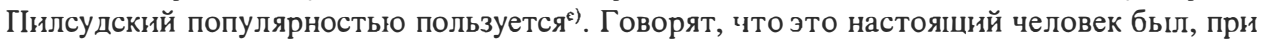
нем лучше было гораздо, чем после него. С удовольствием вспоминают, как он с трибуны сейма называл всех руководителей разными острыми словами ?. Говорят, что это как раз касалось и теперенних руководителей - Рыдз-Смиглы. СлавойСладковского, Бека и проч. ГІонятен поэтому акт Гитлера - возложение венка на могилу ГІилсудского.

В Несвиже посетил замок князей Радзивилов. 3-х этажное кольцом, здание, около двухсот громадных комнат-зал, имеются картины, среди них шедевры, оружие всех веков, отделанное серебром, золотом, знаменитая библиотека с большим количеством книгуникумов на всех языках. Замок представляет громадную художественную-историческую ценность, а библиотеке прямо нет цены. Для сохранения ценностей и описи мною назначены комиссары и группа научных работников и временно запрешено посешение замка кем-бы то ни было без особого разрешения. Так как практика показала. что посещающие товарици, любят прихватить с собою на память какой-нибудь сувенир.

ГІропу совета по следуюшим вопросом:

1. Нами разработана схема аппаратов Временных Управлений, 'гак как без аппаратов им, конечно, не обойтись. Необходимы отделы: административный, продовольственноторговый, финансовый, коммунальный, культурно-просветительный, народоного образования.

2. С хлебом в городах пока обходятся, но Экономсовет должен разрешиить завоз спичик, соль и керосин, так как население не имеет их уже давно, и по этим товарам изголодалюсь.

3. Все электростанции городов Западной Белоруссии работают на нефти. Запасы остались от 3-х до 12 дней. Во избежание их остановки нефть нужно начать завозить сейчас. Кое-где исчерпав запасы станции уже стоят.

4. ГІросим дать также совет по вопросу о ценах. Цены на продовольственные товары, сушествовавпе, я Вам уже сообшал, они пока и остаются. А вот был такой случай, когда без напего разрешения Трансторгпит завез в Молодечно вагонлавку и начај продавать масло по 15-16 руб. или злотых, килограмм, хлеб по 90 коп. килограмм и т.д. Железно.дорожники-рабочие не могли покупать, так как это сразу выбило-бы их из бюджета. Вопрос с ценами, конечно, связан и с вопросом о зарплате.

5. ГІрону также посоветовать когда начинать организацию комсомола - напор, повторяю, молодежы огромный.

6. Наркомпочтель должен рециить вопрос о корреспонденции, марках и почтовых сборах, так как на месте этого решиить нельзя. 
7. В городах имеются частные банки, кооперативные банки и Державный Банк.

В Банках много мелких вкладов, много и крупных. Вкладчики требуют деньги, коегде вы,дают ограниченные сумы, кое-где ожидают указаний.

Нами назначены Комиссары в Банки. Оставииеся суммы опечатаны.

Мы не сгитаем возможным брать на себя какие-бы то ни былю обязательство имеющиеся у Банков перед кем-бы то ни было.

Из частных Банков необхо,димо выдать вклады мелгким вкладчикам. Болыние вклады помецциков-капиталистов, крупных государственных чиновников и осадников считать достоянием народа, и деятельность частных банков после выдачи мелких вкла,дов прекратить, оставив функционировать только Госбанк.

В этом случае, конечно, будут подрерзаны промынленники и крупные торговцы, прово,дивицие свои операцин через частные банки. Вопрос этот сложный ${ }^{\text {s) }}$, поэтому я отелбы иметь указание.

\section{СЕКРЕТАРЬ ЦК КП(б) БЕЛОРУССИИ}

(ПОНОМАРЕНКО)

25-IX-1939 г.

гор. Минск

Nr-1119') (дп)

Kopia oryginału, maszynopis.

Źródło: NARB w Mińsku, zesp. 4, spr. 21, t. 1521, k. 206-211.

a) Wielkie litery i podkreślenie oryginału.

b) Skreślono słowo: „organizowanych”.

c) Skreślono słowa: „dając-określone zadania”.

d) Skreślono słowa: „Za Wołkowyskiem i dalej, wyłączając” i dopisano odręcznie „Za”.

e) Skreślono słowo „dużą” w zdaniu o popularności Piłsudskiego.

f) Wpisano odręcznie, że Piłsudski nazywał polskich przywódców „różnymi ostrymi słowami” w miejsce skreślonego „zasrańcami”.

g) Skreślono słowo: „nadzwyczaj” przed słowem „skomplikowany”.

h) Numer wpisano odręcznie. 


\section{Dokument 5}

1939 (po 25 października), Minsk - Sprawozdanie rzqdowej komisji ds. uchodźców z prac związanych z ustaleniem liczebności i rozmieszczeniem uchodźców na obszarach Biatorusi.

\section{СЕКРЕТАРЯМ ЦК КП(б)Б}

тов. ГIOHOMAPEHKO II.K. тов. К УЈІАГИНУ М.Б. тов. ГРЕКОВОЙ Н.Г.

\section{ГІРЕДСЕДАТЕЈІЮ СОВЕТА НАРОДНЫХ КОМИССАРОВ БССР}

ІІостановлением СНК БССР за $\mathrm{N}^{0} 773$ от 25.X-1939 г. былға утверждена ІІравительственная комиссия в составе 3-х человек по размеццению беженцев на территориг Белорусской ССР.

ІІравительственной Комиссией был разработан и представлен план работы в СНК БССР, который был одобрен. В указанном плане былг намечено произвести разгрузку от беженцев по нижеследуюцим городам Западной Белоруссии:

1. Белосток

2. Брест-Литовск

3. ІІинск

4. Гродно

5. Јиида

6. Барановичи

7. Слоним

8. Молодечно.

ІІо согласовании с Отделом Кадров ЦК ІІартии были посланы в вышеуказанные города по одному особоуполтномоченному и 2-х помощников особоуполтномочнных, которым было предложено, в основу своей работы, по трудоустройству и размещению беженцев в городах Западной Белоруссии и по вывозу из городов Западной Белоруссии полтожить следугоцие принципы:

1. Размешение на месте.

2. Размешение на промышленных предприятиях, совхозах и МТС.

3. Размещение беженцев б. членов крестьянских комитетов и сельского актива в колтхозах.

Особоуполтномоченные, совместно с Временными Управлгениями производили на месте учет беженцев по: фамилии, имени и отчеству, место откуда прибыл, роду занятий, квалификации, национальности, году рождения и состава семьи, было выявлено следующее количество беженцев: 
1. Белосоток .............................. 25.000 ч.

2. Брест-Јитовск ..................... $10.000 "$

3. Г р о дн о о ………........... 1.900 ";

4. Барановичи …........................ 1.440 "

5. II и н с к .............................. 1.771 "

6. ЛІ и д а …............................. 975 "

7. Молодечно …........................ 1.700 "

8. С ли о н и м.......................... $2.000 "$

Итого ................. 44.786 чель.

ІІравительственной комиссией было ориентировочно намечено к размешению по областям, по согласованию с СНК БССР, следующее количество беженцев:

1. Минская облтасть ................. 6.000 чел.

2. Витебская " ....................... 6.000 "

3. Могилевская " ..................... 5.000 "

4. Гомельская " ...................... 4.000 "

5. Полесская " .......................... 2.000 "

Итого ................. 23.000 чел.

В областях, при председателях Оргкомитетов Верхного Совета БССС по постановлениго СНК БССР были созданы областные комиссии по приему, размешениго и трудноустройству беженцев непосредственно в области, при чем, каждая комиссия дала заявку в Центральную комиссию на прием соответствуюгцего количества беженцев, как то:

$\begin{array}{ll}\text { 1. Витебская облгасть } & -8.969 \text { чел. } \\ \text { 2. Могилевская " } & -5.286 " \\ \text { 3. Минская " } & -4.602 " \\ \text { 4. Гомечльская " } & -2.556 " \\ \text { 5. ІІолесская " } & -2.280 "\end{array}$

Итого - 23.693 чел.

Согласно постановления СНК БССР, ІІравительственной комисси было предложено разместить всего 20.000 челювек на территории Белорусской ССР.

В основном, при направлении беженцев в облгасти - комиссия придерживалась утвержденного количества СНК БССР. Так как отдельные области, как например Витебская и друг. недостаточно серьезно подошли к даче заявок на размешение беженцев, не учитывая жилищнуго плогцадь, а также квалиффикации.

В болынинстве, от областей поступа.ли заяавки на крестьян при чем, при учете беженцев в Западной Белоруссии, крестьян очень мало было зарегистрировано, а пос му приходолось не полностыо удовлетворять заявки областей по указанному пункту. Также при регистрации беженцев было исклгочительно много портных, сапожников и слесарей-металистов.

Между членами комиссии были распределены обязанности как то: тов. Горин - отвечает за учет и вывозку беженцев из Западной Белоруссии, тов. Иванов - отвечает за подачу подвижного состава, тов. Решетников - отвечает за прием и размещение беженцев. 
Движение беженцев было организовано чеврез следуюшие пограничные станции, как то: Негорелое, Радошковичи и Крулевшизна. На указанных станциях были организованы обменные пункты на обмены польских злотых на советские деньги, при чем разрешалось каждому семейному обменять 40 злотых и холостякам - 20 злот, также на указанных станциях были организованы горячие обеды и продовольственное снабжение беженцев.

Для оказания материальной помоши беженцам в Западной Белоруссии было особоуполгомоченным переданы специальные ассигнования, как то:

1. Белостоку

65.000 рыб.

2. Пи н с к

$20.000 "$

3. Брест-Литовск

$65.000 "$

4. Моло,дечно

$25.000 "$

5. Г р о д н о

$25.000 "$

6. Барановичи

$25.000 "$

7. Л и д а

$15.000 "$

8. Слоним

15.000

9. Бреслав

$30.000 "$

$$
\text { Итого } 285.000 \text { руб. }
$$

Для оказания материальной помоши и организации, прием и размешение беженцев передано в распоряжение предсе,дателей Оргкомитетов областей:

1. Минской области $\quad-460.000$ p.

2. Витебской " $\quad-585.000 \mathrm{p}$.

3. Гомельской " $\quad-450.000$ p.

4. Могилевской " $\quad-550.000$ p.

5. Полесской " $\quad 200.000$ p.

Итого - 2.245.000 рубл.

Также в распоряжение комиссии было оставлено 10.000 рублг. на предмет оказания продовольственной помоши, проходяцим эшелонам.

Наркомздраву БССР переведено 180.000 руб. на выдачу белья при саноб-работке.

Материальная помошь оказывалась нуждаюгцимся - семейным до 100 рубл., холостя кам до 25 рубл.

На всех пограничных станциах, а также по месту прибытия беженцев было Наркомздравом БССР организована санитарная обработка всех прибываюших беженцев, которые после чего размешались по районам.

IТо имеюгцимся сведениям в БССР прибыло следуюшее количество беженцев:

\begin{tabular}{lc|c|c}
\hline $\begin{array}{l}\text { Наименование } \\
\text { областей }\end{array}$ & $\begin{array}{l}\text { Количг. бежен- } \\
\text { цев необход. по } \\
\text { олгну }\end{array}$ & $\begin{array}{l}\text { Колич. бежен- } \\
\text { необход. по } \\
\text { заяавк. област. }\end{array}$ & $\begin{array}{l}\text { Фактически } \\
\text { поступило бе- } \\
\text { женцев }\end{array}$ \\
\hline 1. Могилевская & 5.000 & 5.286 & 7.150 \\
2. Витебская & 6.000 & 8.969 & 6.740 \\
3. Минская & 6.000 & 4.602 & 4.363 \\
4. Гомельская & 4.000 & 2.556 & 2.333 \\
5. ІПолесская & 2.000 & 2.280 & 1.885 \\
\hline Нтого & 23.000 & 23.693 & 22.471
\end{tabular}


ПРИМЕЧАНИЕ: В указанные сведения вхо,цит заявка Белор.ж.д.

и Белстройпуть - 1.642 чел.

Из общего количества беженцев 22.471 - имеется 4.114 семейств и 3.928 ,детей.

По специальности прибыло следующее количество:
а) Слесарей и механиков
902 чел.
б) Т ок а ре й
$360 "$
в) Металистов
$412 "$
г) Текстилщ. и трикотажн.
$636 "$
д) Столярей и плотников
$1065 "$
е) Портн. и белошвейн.
$2896 "$
ж) Сапожников и заготовгц.
$1403 "$
3) Ш о фе р о в
167
и) ІТечатников
165
к) Кожевников
$163 "$
л) Парикмахеров
204
м) Приказчиков
$294 "$
н) Счетных работников
$105 "$
о) Разных мед. работн. и фармац.
90 "
п) Учителей и воспиталей
62 чел.
р) М я с н и к о в
$191 "$
c) Крестьян и батраков
$281 "$
т) Детей, которые приб. с семьями
$3928 "$

Другие разные профессии, без профессий домохозяек и чернорабочих - 9145 чел.

В основном беженцы прибыли со следующих городов:

\begin{tabular}{|c|c|}
\hline Из Варшавы & 5.834 чел. \\
\hline JI о д зи и & $690 "$ \\
\hline В и ли ь н о & $799 "$ \\
\hline С у в а лки & $696 "$ \\
\hline В ло д о в о & $744 "$ \\
\hline Пултуска & $1.960 "$ \\
\hline Остров-Мазовецк & $955 "$ \\
\hline Р у әка ны & $600 "$ \\
\hline Пр а сныш & $438 "$ \\
\hline$Г$ о в о рово & $198 "$ \\
\hline С едльц е & $911 "$ \\
\hline ЈI у к о в & $398 "$ \\
\hline
\end{tabular}

Из разных мелких городов и местечек, откуда отошли части PККА - 8247 чел.

Необхо.димо отметить, что ряд областей исключительно плохо отнеслись к вопросу размещения беженцев, особенно Витебская область, которая без всякого учета направля ла ліодей в районы, как Толочинский район, Богушевский район, где люоди по сегодня Іций день ходят без работы. Также целый ря,д районов без всякого запроса. Центральной комиссий направляют в г. Минск беженцев для их трудоустройства, что вызывает спра- 
ведливое нарекание и недовольство со стороны последних. В Толочинском районе на лесоразработки были посланы 15-ти летние дети, которые были ІІрави-тельственной комиссией немедленно отозваны и посланы в Белаптекоуправление на работу в качестве учеников фармацефтов. В БССР было направлено из городов Западной Белоруссии следующее количество беженцев:

Наличие беженцев в городах Западной Белоруссии и количество вывезенных в БССР

\begin{tabular}{l|l|l|c}
\hline $\begin{array}{l}\text { Наименование } \\
\text { городов }\end{array}$ & $\begin{array}{l}\text { Колич. выявлен. } \\
\text { беженцев }\end{array}$ & $\begin{array}{l}\text { Колич. вывезен. } \\
\text { бежкенцев }\end{array}$ & $\begin{array}{c}\text { Осталось на } \\
\text { месте по предв. } \\
\text { подсчетам }\end{array}$ \\
\hline 1. Белосток & 25.000 & 11.814 & 13.186 \\
2. Брест-Литовск & 10.000 & 5.916 & 4.084 \\
3. Г р о дн о & 1.900 & 855 & 1.045 \\
4. Барановичи & 1.440 & 1.604 & - \\
5. Молодечно & 1.700 & 487 & 1.219 \\
6. С л о н и м & 2.000 & 544 & 242 \\
7. Ј и д а & 973 & 733 & 1.253 \\
8. П и н с к & 1.711 & 518 & \\
\hline
\end{tabular}

\subsection{5}

22.471

22.315

Как видно из вышеизложенного, в городах Западной Белоруссии еще имеется много беженцев, которых необходимо трудоустроить. В гr. Брест-Јитовск и Белосток, где еще в данное время имеется большое количество беженцев - они все размещен̆ы в дачных местах и в отдельных домах указанных городов.

Необходимо обратить особое внимание, что отдельные области недостаточно и по сей день трудоустроили и разместили беженцев, а посему необходимо предложить Облисполкомам, Горсоветам и Райисполккомам обратить особое внимание на проведение указанной выше работы.

Для снабжения промтоварами беженцев - спущены специальные лимиты для снабжения их, как то:

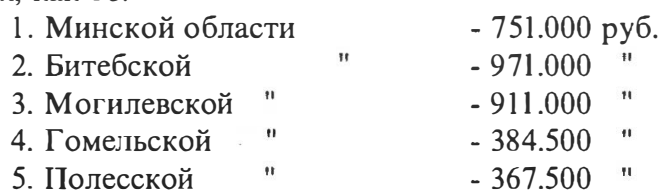

В указанные суммы вошли белье: мужское, дамское и детское, обувь резиновая и кожканая, постельные принадлежннсти, трикотаж, ватние брюки и телггрейки, а такље верхняя одежда.

Личным выездом на место в Брест-Јитовск и Белосток мною установлено, что в Брест-Јитовске имеется много беженцев, околг 4.500 челІ. из гражданского населения кои ждут открытия гранищы на выезд в Германию.

В связи с закрытием границы - никуда не уезжают, а наоборот среди них циркулиругот слухи, что будет организовано возле Брест-Јитовска 5 пунктов на границе для отправки их в Германию, а посему по,дходят новые лю,ди из Запа,дной Украины. Аналогичное положение имеется и в Белостоке, которые открыто заявлягот, что они желают выехать в Германию, или же поехать за семьями.

Указанных людей никто не регистрирует, а посему в Брест-Јитовске, по инициативе 
одного из беженцев стихийно возникла регистрация по порядковому списку для отправки в Германию. Оперативной группой указанная регистрация была приостановлена.

Временные Управления указанных горо,дов не имеют ннкаких указаний по данному вопросу, а посему указанные беженцы занимаются разными недоброжелательными вешами, а также спекуляцией.

В связи с болышей перегрузкой указанных горо,дов - в Брест-Јитовске были от.дельные вспынки заболеваний инфекционными болезнями, при чем, Наркомз,црав сразу же принял меры и организовал больницу.

В дальнейпем считаю необхо,цимым следующее:

1. Необхо,цимо немедленно разрешить вопрос о вывозке беженцев из городов Западной Белоруссии в другие области Союза ССР, так как Белорусская ССР полностью заселена беженцами.

2. В связи с тем, что в давное время все беженцы недостаточно благоустроены - необходимо, при СНК БССР создать постояннодействуюшую комиссию с рабочим аппаратом по трудоустройству и размешению беженцев.

3. В связи с тем, что по городам: Лиды, Молодечно, Барановичи, Гро,дно, Слоним, ІПинск - работа с беженцами в основном закончена, особоуполюномоченных и их помоцников необходимо отозвать и их функции передать Временным Управлениям.

\title{
ІІРЕДСЕДАТЕЛЬЬ ІІРАВИТЕЈЬСТВЕННОЙ КОМИССИИ
}

\author{
ЧЈЛЕНЫ: (РЕШЕТНИКОВ, ИВАНОВ) - podpisy ${ }^{\text {h) }}$
}

Kopia, potwierdzona.

Źródło: NARB w Mińsku, zesp. 4, sor. 21, t. 1512, k. 235-242.

a) Wielkie litery i podkreślenie oryginału.

b) Wpisane odręcznie.

\section{Dokument 6}

1939 październik 1, Moskwa - Uchwata Biura Politycznego WKP(b) z 1.10.1939 r. okres'lajaca zakres sowietyzacji na obszarach wschodnich ziem Polski, zajętych przez Armię Czerwona.

252. - Вопросы Западной Украины и Западной Белоруссии

$(34)^{b)}$

1. Созвать Украннское Народное Собрание из выборных по областям Запа,цнй Украины (территория быв. воеводств Станиславского, Львовского, Тарнопольского и Луцкого) и Белорусское Народное Собрание из выборных по областям Западной Белоруссии (территория быв. воеводств Новогрудского, Вијенского, Белостокского и Полесского).

Эти Народные Собрания дольжны: 1) утвердить передачу помеццичих земель крестья нскими комитетами; 2) ренить вопрос о характере создаваемой вјасти, т.е. долюна Јги быть эта власть советская или буржуазная; 3) решить вопрос о вхождении в состав СССР, т.е. о вхождении Украинских областей в состав УССР, о вхождении Белорусских облгастей в состав БССР; 4) репить вопрос о национализации банков и крупной промынленности. 
2. Украннское Народное Собрание созвать в г. Јьвове, Белорусскее Народное Собрание - в г. Белостоке.

3. Днем выборов в Наро,дные Собрания назначить воскресенье 22 октября с.г.

Днем созыва Народных Собраний назначить 26 октября с.г.

4. Выборы в Народные Собрания производить на основе всеобцего, прямого и равного избирательного права при тайном голюсовании.

Правом выбора в Народные Собрания пользуются все граждане мужского и женского пола, достигшие 18 лет, независимо от расовой и национальной принадлежности, вероисповедания, образовательного ценза, социального происхож,дения, имушественного положения и прошлой ,деятельности.

5. Установить избирательную норму по выборам в Народные Собрания: 1 депутат от 5 тысяч избирателей.

6. Создать Комитет по организации выборов Наро,цного Собрания Западной Укранны и Комитет по организации выборов Наро,дного Собрания Западной Белоруссии.

Инициативу по созыву Нариодных Собраний и созданию Комитетов берут на себя Временные управления городов Јьвова и Белостока, которые обрапаются к Временным управлениям областных городов с приглашением выделить представителей в Комитеты по организации выборов. В составе Комитетов должны быть Временные управления г. Јьвова и г. Белостока плюс по одному представителіо от каждой области, кроме того два - от крестьянских комитетов, два - от интеллиигенциц, два от рабочіих органи-заций.

Для помопци в организации выборов в Комитеты по организации выборов Народных Собраний должны быть делегированы по три представителя от президиумов Верховных Советов УССР и БССР.

Порядок организации выборов установливается Комитетами и публикуется во всеобщее сведение. В отношении организации выборов руководствоваться практикой выборов в Верховные Советы СССР и Союзных Респуб.лик, с необходимым упрошением, применительно к сжатым срокам выборов.

Ответствовенность за проведение выборов в областях (быв. воеводства) возлагается на Временные управления областей, городов, уездов.

7. Право выставления кандидатов в депутаты Народных Собраний обеспечивается за крестьянскими комитетами, Временными управлениями, собраниями рабочих по предгриятиям, собраниями рабочей гвардии, собраниями интеллигенциі1.

Эти собрания выбираго также доверенных лиц, которые затем на окружных совешаниях доверных гиц договариваются об обцей кандидатуре по округу.

8. Ґзбирательную кампанию проводить под лозунгами: установления Советской власти на территории Западной Украины и Западной Белоруссии, вхождения Западной Украины в состав УССР и Западной Белоруссии в состав БССР, одобрения конфискации помешичьих земель, требования национализации банков и крупной промышленности.

9. По вопросам порядка дня Народными Собраниями должны быть приняты декларацин, текст которых подготовить ЦК КП(б) Укранны (т. Хрушеву) и ЦК КГІ(б) Белоруссии (т. Пономаренко).

10. ГІриступить к созданио коммунистических организаций в Западной Украине и Западной Белоруссии, начав прием в канди,даты из числа передовых рабочих, оказавших помонь Красной Армии в борьбе с враждебными элементами и проявивших себя в деле установления нового, революционного порядка, а также из числа передовых крестьян и интеллигенции.

Бывших членов Коммунистической партии Западной Украины и Коммунистической партии Западной Белоруссии принимать в ряды ВКП(б) не огульно, а в индивидуальном порядке после тпцательной и неторопливой проверки.

11. Демобилизовать из рядов Красной Армин, действуюшей на украинском 
и белорусском фронтах, в распоряжение Украннской партийной организации 1.000 коммунистов и 500 комсомольцев и в распоряжение Белорусской партийной организации 800 коммунистов и 400 комсомольцев для использования на партийной, комсомольской и другой работе на территории Западной Украины и Западной Белоруссин.

12. Обязать ЦК КП(б) Украины мобилизовать для партийной и комсомольской работы в Западной Украине не менее 2.000 коммунистов и комсомольцев, и ЦК КП(б) Белоруссии дла работы в западной Белоруссии не менее 1.500 коммунистов и комсомольцев, главным образом, украинцев и белоруссов.

13. Обязать ЦК КП(б) Украины и ЦК КП(б) Белоруссии назначить уполномоченных на каждое воеводство по вопросам организации партийной работы. Предложить ЦК КП(б) У и ІЦК КП(б) Б в двухдневный срок представить кандидатуры уполномоченных на утверждение ЦК ВКП(б).

14. Организовать Временные областные управления действугоцие на территориях бывших воеводств Западной Украины и Западной Белоруссии, в составе 4-х человек (два представителя от армейских органов, один от НКВД, один от Временного управления областного города).

15. Не ломая пока системы организации профсоюзов по профессиональноцеховому признаку, как она существует в настояцее время, поддерживать инициативу по организации профсоюзов на основе об'единения всех рабочих данного предприятия, создавая в этих целях фабрично-заводские комитеты.

16. Поручить т. ІШвернику выделить группу профсолозных работников дія посылки в Западную Украину и в Западную Белоруссию с целью изучения вопросов об условиях труда, о состянии заработной платы и для оказания помоци в организации профсоюзной работы, обязав эту группу все свои предложения согласовывать с ЦК КІІ(б)У и ЦК КП(б)Б.

17. Назначуить от Временных областных управлений комиссаров во все банки на территории Западной Украины и Западной Белоруссии, для чего поручить т. Булганину отобрать соответствуюгцее число знагоцих банковскую работу людей в трехдневный срок, согласовав их кандидатуры с ILK KII(б)У и IЦK КІІ(б)Б.

Для руководства деятельностыо банков обязать т. Булганина выделить временных уполномоченных Госбанка в г. Јьвове и г. Белостоке.

18. Комиссары банков обязаны: а) проверить состояние текуцих счетов и ценностей банков; б) принять меры к открытиго и нормальному функционированию банков; в) обеспечить необходимое текущее кредитование промынленных и хозяйственных предприятий.

Считать необходимым повсеместный переход на советскую валюту.

Установить, что ни одна банковская операция не может быть произведена без разрешгения комиссара банка.

В случае, если тот или иной банк не может быть восстановлен для нормального функционирования, передать его операции другим банкам.

19. Операции с иностранными банками пока не производить.

20. Считать целесообразным выдачу денег по вкладам частных лиц не свынге 300 рюблей в месяц с разрешения комиссаров банков.

21. ІПринять меры к немедленному открытиго сберегательных касс. Выдачу денег по вкладам в сберегательные кассы установить в размере не более 300 рублей в месяц.

22. ІПредприятия, владельцы конх сбежали или саботируют их работу, национализируются и Временные управления назначают управляюгцих для ведения дел этих предприятий.

23. Обязать ЦК КІІ(б)У и ЦК КІІ(б)Б представить в декадный срок в ЦК ВКІІ(б) 
предложения о порядке национализации крупных предприятий и список предприятий, подлежацих национализации.

24. Обеспечить открытие магазинов, базаров, хлебопекарен и прочих предприятий по бытовому обслуживанию населения, и обеспечить их нормальное функционирование.

25. Магазины, оставленные владельцами, передать в распоряжение Временных управлений и открыть в них торговлю силами Временных управлений или рабочих кооперативов.

26. ГІоручить Наркомторгу СССР совместно с Наркомторгами УССР и БССР развернуть в главных городах Западной Белоруссии и Западной Украины государственные магазины.

27. Установить следуюцце цены: на соль - 20 коп. за килограмм на территории Западной Украины, 30 коп. за килограмм на территории Западной Белоруссии; на спички - 3 коп. за коробку маленького формата; на керосин - 65 коп. за литр на территории Западной Украины, 66 коп. за литр на тер-ритории Западной Белорусии; на махорку 50 коп. за пачку в 50 грамм.

28. Горучить Наркомату Связи (т. ГІересыпкину) совместно с СНК Украины и СНК Белоруссии отобрать в двухдневный срок работников Наркомсвязи, в первую очередь из украинских и белорусских контор Наркомсвязи, для посылки их в Западную Украину и Западную Белоруссию для организации областных и городских Управлений почтовотелеграфной связи, оформив их назначение через Военные Советы фронтов.

29. ГІоручить т. Пересыпкину подобрать в однодневный срок и представить на утверждение ЦК ВКП(б) по одному уполномоченному для Западной Белоруссии и Западной Украины по организации почтово-телеграфной связи на территории Западной Украины и Западной Белоруссии, оформив их назначение через Военные Советы фронтов.

30. Разрешить оплату корреспонденции как польскими, так и советскими марками.

Обязать т. Пересыпкина отравить самолетом в распоряжение уполномоченных советские почтовые марки, обеспечив их распространение по всем почтово-телеграфным отделениям.

31. Для обеспечения нужд Временных управлений в автомашинах как легковых, так и грузовых, поручить ЦК КГІ(б) Украины и ЦК КІІ(б) Белоруссии определить потребное количество машин, а Военным Советам фронтов выделить это количество машин из числа трофейных.

32. ІІоручить т.т. Берия и Мехлису в трехдневный срок представить предложения по вопросам о военнопленных и беженцах.

33. ГІредложить Наркоминделу ликвидировать иностранные консульства, находяциеся в городах Западной Украины и Западной Белоруссии.

Oryginał, maszynopis.

Źródło: Rosyjskie Centrum Dokumentacji i Studiów Najnowszej Historii w Moskwie, zesp. 17, spr. 3, t. 1014, k. 57-61. por. też A. Sudol, Poczqtki sowietyzacji Kresów Wschodnich. Jesień 1939, Bydgoszcz - Toruń 1997, s. 404-411.

a) Podkreślenie oryginału.

b) Wpisane odręcznie. 


\title{
Dokument 7
}

1939 październik 2, Mińsk - Stenogram punktu 4 z posiédzenia Biura KC KP(b)B poświęconego sprawom Zachodniej Bialorusi.

Протокоп nr 90

\section{СТЕНОГРАММА \\ ЗАСЕДАНИЯ БЮОО ЦК КП(б)Б ОТ 2.X - 1939 года}

\author{
ПРЕДСЕДАТЕЛЬСТВУЕТ - Т. ПОНОМАРЕНКО
}

ПРИСУДСТВУЕТ - члены Бюро ЦК КП(б)Б - т.т. Грекова, Кулагин, Наталевич, Киселев, Матвеев.

I. СЛУШАЛИ: Вопросы Западной Белоруссии (докл. т. ІТономаренко).

Нам нужно будет прежде всего решить вопрос о том, чтобы собрать послезавтра в г. Волковыске совешание всех председателей временных управлений, для того, чтобы ознакомить иж с директивой ЦК ВКП(б), тем более, что накопился опыт работы, который может уточнить целый ряд моментов.

4.Х.с. г. в 12 часов созвать в Волковыске совещание всех председателей временных управлений.

Обращение городского управления Белостока им надо будет помочь написать. ІТоручить здесь товарицу написать это обращение, они могут внести в это обращение свои соображения, дополнения, но основа должна быть здесь написана.

Поручить это дело т. Малину, с таким расчетом, чтобы 4-го октября на совешании товарици уже могли ознакомиться с этим обращением.

Делегировать от Верховного Совета БССР для помогци в проведении выборов на народные собрание т.т. Наталевича - председателя Президиума Верховного Совета БССР, ІІанкова - секретаря Президиума Верховного Совета БССР и Грекову - председателя Верховного Совета БССР.

ІТорядок организации выборов. Этот порядок надо написать упрощено. За порядок организации выборов надо сейчас же засесть, начать с принциниальных вопросов основа выборов, взять нацу инструкциго о выборах и просмотреть, без чего нельзя обойтись, что нужно добавить.

Это нужно поручить т. Наталевичу, при чем такой проект, набросив этого дела черновой, может быть грубый, не совсем удовлетворительный, этого смуцаться не нужно, - надо написать немедленно. Пусть мы этот черновник зачитаем на совещании нашим товариццам, выслушаем их замечания, так - что послезавтра в 12 часов дня он должен быть написан. Во всяком случае набросок должен быть готов, чтобы получить совет наших товарищей. Товарици могут подсказать в процессе обсуждения этой инструкции, они изучат, поймут ее.

Значит нет возражений, чтобы поручить т. Наталевичу представить проект порядка организации выборов. (ГІринимается)

Деклараций по вопросом повестки дня народного собрания - серьезнейший политический документ. Значит народные представители собрались на народное собрание, выслушивагот сообщения, выступают в прениях, тебуют конфискации помецичих земель и принимают декларацию.

Эта декларация - серьезнейпий политический документ, он должен быть написан очень серьезно, при чем нужно угесть опыт деклараций, которые у нас имеются 
о национализации промышленности и Банков, учесть Ленинский язык, надо обложиться книгами, материалами и исходя из цели, которую мы хотим добиться зтой дек.лорацией, ее написать, кому это предложить сделать, чтобы представить на рассмотрение Биюро ЦК KГІ(б)Б, при чем деклораций будет 4:

1) О разделе помецичих земель, 2) Об установлении Советской власти, 3) О вхождении в состав БССР и 4) О национализации промышленности и Банков.

ІІоручить т.т. Малину и Эйдинову написать эти дек.лорации, с привлечением товаришей по их усмотрению, но обязательно коммунистов.

По вопросу отбора 1500 коммунистов и комсомольцев главным образом для партийной и комсомольской работы. У меня имеется проект распоряжения: по Минскому Обкому -- 250 коммунистов и 250 комсомольцев, по Витебскому -- 200 коммунистов и 200 комсомольцев... (читает ${ }^{1}$ )

Утвиердить распределение этих 1500 коммунистов и комсомольцев по областям.

Предложить обкомам КГІ(б)Б подобрать этих людей и послать сюда в пятидневный срок.

Этим люодя выдавать специальные удостоверения, для какой работы они туда командируются.

Об уполномоченных по организации партийной работы. Нужно иметь 4 таких уполномоченных, но это не значит, что мы просто пошлем уполномоченного и не дадим ему никакого аппарата. Но сехчас вопрос об уполномоченных.

Товариша Гершмана оставить в Белостоке уполномоченным по организации партийной работы, тов. Бойкачева -- в Вильно, тов. Карасева (в Полесскую область) и т. ГІознякова - в Новогрудскую област.

О временных управлениях облгастей и параллельно и городских управлениях.

ІІредседателями временных управлений облтастей назначить т.т. Гайсина, Жилянина, Тура, Калинина.

Городские управления:

ГІредседателем временного городского управления -- г. Вијьно назначить тов. Краскова.

ІІредседателем временного городского управления Новогрудка -- тов. Кузнецова.

Председателем временного городского управления в Белостоке -- тов. Спасова.

ІІредседателем временного городского управления Пинска -- тов. Дружинина.

Председателем временного городского управления в Волковыске -- тов. Беляева.

ГІредседателем временного городского управления в г. Лиде -- тов. Семенова.

ГІредседателем временного городского управления в Г. Брест-Литовске -- тов. Горелика.

Есть предложение уполномоченным по организации связи послать тов. Верухина.

Тов. Кравчука вернуть в БССР.

ІІоручить т. Захарову в двухдневный срок определить потребность временных управлений в машинах.

Горучить т. Попову подобрать по 3 человека в помопьь уполномоченному по организации партийной работы (в виде инструкторов) и по одному техническому работнику (комсомолка или комсомолец) для каждого уполномоченного по организации партийной работы.

Подобрать этих людей в течение однодневного срока.

Поручить тов. Малину подготовить для отправки в Западную Белоруссию Устав ВКП(б), программу ВКП(б), портреты вождей, значки и т.д. в распоряжение уполномоченных по организации партийной работы для продажи через торговую сеть (киоски).

Пригласить для встречу с трудяпцимися Советской Белоруссии делегацию рабочих, 
крестьян и интеллигенции Западной Белоруссии в количестве 25 человек.

Считать целесообразным посылку на народное собрание в гор. Белосток делегапию трудянихся Советской Белоруссин в количестве 50 человек.

Просить ЦК ВКП(б) утвердить это решение.

Поручить т.т. Малину и Азиркому подготовить мероприятия по культурному обслуживанию делегатов народного собрания в Западной Белоруссии.

ГІоручить тов. Малину продумать вопрос о мероприятиях по печатной нагдядной агитапин.

Oryginał, maszynopis.

Źródło: NARB w Mińsku, zesp. 4, spr. 3, t. 802, k. 1-5.

a) Duże litery oryginału

1. Odczytał dalej: z obkomu witebskiego - 200 komunistów i 200 komsomolców, z obkomu homelskiego - 125 komunistów i 200 komsomolców, z obkomu mkohylowskiego - 125 komunistów i 150 komsomolców. W okresie późniejszym uwzględniono również obkom poleski.

\section{Dokument 8}

1939 październik 4, Wolkowysk - Stenogram z narady przewodniczących zarządów tymczasowych Zachodniej Biatorusi.

Б.П. ${ }^{\text {a) }}$

\section{T E H O Г P A M A \\ СОВЕІЦАНИЯ ІІРЕДСЕДАТЕЈІЕЙ ВРЕМЕННЫХ УІІРАВЈІЕНИЙ ЗАПАДНОЙ БЕЈIOРУССИН ${ }^{\text {b) }}$}

гор. Волковыск

4.X.-1939 г.

Председательствугоций - т. Ковалев.

KOBAJIEB. - Товарици, совеццание председателей Временных Управлений Западной Белорусси об'являяо открытым.

ГІо решению ЦК партии и военного командования Западного Фронта имеет слово член Военного Совета, секретарь ЦК товариц Гономаренко.

ПОНОМАРЕНКО. - Некоторое время прошло, опыт накопился, и елце больше накопилось вопоросов, которые должны разрешаться, и вокруг которых напни товарици хо.цят, а ухватится за них бояться.

Накопилось много положительного опыта в работе различных Временных Управлений, есть отдельные элементы и отприцательные, о которых мы также применем тут сказать, чтобы недопустить нх повторения.

Но во всяком случае возникла мысль о созыве настояпцего совеццания.

ГІредварительно, конечно, были поставлены все волросы, которые мы могли получить от вас, перед ЦК ВКГІ(б), куда я выезжал. Комиссия в составе т.т. Хруцева, Жданова, Берия, и я был в комиссии, также советовались с т. Сталином, - приняли решение бюро и это репение бюро утверждено как решение ЦК. Это решение я вам сейчас зачитаю.

(Зачитывает п. 1-3) 
"1. Созвать Украинское Народное Собрание из выборных по областям Западной Украины (территория быв. воеводств Станиславского, Јьвовского, Тарнопольского и Јуцкого) и Белорусское Народное Собрание из выборных по областя Западной Белоруссии (территория быв. воеводств Новогрудского, Виленского, Белостокского и Полесского).

Эти Народные Собрания должны: 1) утвердить передачу помепичынх земель крестья нскими комитетами; 2) решить вопрос о характере создаваемой власти, т.е. должна ли быть эта власть советская илги буржуазная; 3) решить вопрос о вхождении в состав СССР, т.е. о вхождении Украинских областей в состав УССР, о вхождении Белорусских областей в состав БССР; 4) решить вопрос о национализации банков и крупной промышленности.

2. Украинское Народное Собрание созвать в г. Јьвове, Белорусское Народное Собрание - в г. Белостоке.

3. Днем выборов в Народные Собрания назначить воскресение 22 октября с.г.".

Днем созыва Народных Собраний назначить 26 октября с.г.

Сейчас на ЦК ВКП(б) поступило изменение в отношении дня созыва Народных Собраний, для того, чтобы можно было учесть опыт, украинское Народное Собрание будет 26 октября, а Белорусское Народное Собрание (28 октября).

(Зачитывает п. 4-6)

"4. Выборы в Народные Собрания производить на основое всеобщего, прямого и равного избирательного права при тайном голюсовании.

ІТравом выбора в Народные Собрания пользуются все граждане муљского и женского пола, достигшие 18 лет, независимо от расовой и нацнональной принадлежности, вероисповедания, образовательного ценза, социального происхождения, имущественного полюжения и прошлой деятельности.

5. Установить избирательную норму по выборам в Народные Собрания: 1 депутат от 5 тысяч избирателей.

6. Создать Комитет по организации выборов Народного Собрания Западной Украины и Комитет по организации выборов Народного Собрания Западной Белоруссии.

Инициативу по созыву Народных Собраний и созданию Комитетов берут на себя Временные управления городов Јьвова и Белостока, которые обращаются к Временным Управлениям областных городов с приглашением выделить представителей в Комитеты по организации выборов. В составе Комитетов должны быть Временные управления г. Јьвова и г. Белостока плюс по одному представителю от каждой области, кроме того два - от крестьянских комитетов, два - от интеллигенции, два от рабочих органи-заций.

Для помопци в организации выборов в Комитеты по организации выборов Народных Собраний должны быть делегированы по три представителя от президиумов Верховных Советов УССР и БССР".

(ІШум в зале).

У вас возникают вогросы, но вы сами ответите на эти вопросы (смех).

По п.6. Этот вопрос мы долюжны конкретно сегодня решить. Мы долюжны с вами его здесь подготовить.

Инструкция уже разработана, возможно мы ее с вами здесь обсудим и дадим комитетам.

Как видите из решения комитетов по облгастям нет, есть комитет обпцй по Западной Белоруссии, а там: областные управлгения, городские управле-ния, уездные управления.

(Зачитывает іІ. 7-8)

"7. Право выставления кандидатов в депутаты Народных Собраний обеспечивается за крестьянскими комитетами, Временными управлениями, собраниями рабочих по 
предприятиям, собраниами рабогей гвардии, собраниями интеллигенции.

Эти собрания выбирают также доверенных лиц, которые затем на окружных совегцаниях доверенных лиц договариваются об общей кандидатуре по округу.

8. Избирательнуго кампанию проводить под люзунгами: установления Советской власти на территории Западной Украины и Западной Белоруссии, вхождения Западной Украины в состав УССР и Западной Белоруссии в состав БССР, одобрения конфискации помегцичьих земель, требования национализации банков и крупной промыпленности".

IІо п. 8 - Как видите, лозунги для агитации совериенно жизненные и они будут поддержаны, конечно, всеми.

(Зачитывает п. 9-10)

"9. IТо вопросам порядка дня Народными Собраниямидолгжны быть приняты декларации, текст которых подготовить ЦК КІІ(б) Украины (т. Хрущеву) и ЦК КІІ(б) Белоруссии (т. ІТономаренко).

10. ІПриступить к созданию коммунистических организаций в Западной Украине и Западной Белоруссии, начав прием в кандидаты из числа передовых рабогих, оказавпии помоцць Красной Армии в борьбе с враждебными элементами и проявивпиих себя в деле установления нового, революоионного порядка, а также из числа передовых крестьян и интеллиигенции.

Бывпиих членов Коммунистической партии Западной Украины и Коммунистической партии Западной Белоруссии принимать в ряды BKIT(б) не огульно, а в индывидуальном порядке после тццательной и неторопливой проверки.

ІПорядок организации выборов установливается Комитетами и публикуется во всеобщее сведение. В отношении организации выборов руководствоваться практикой выборов в Верховные Советы СССР и Согозных Республик, с необходимым упрощением, применительно к сжатым срокам выборов.

Ответственность за проведение выборов в областях (быв. воеводства) возлагается на Временные управления областей, городов, уездов".

По п. 10 - Я думіо, что у вас в каждом городе, повете, области вы знаете таких люодей, в отнопении котоых опибок быть не может, которые уже показали себя, кто они.

У нас в проекте по вопросу о приеме в партию было написано: "Не огульно, а индивидуально", а тов. Сталин добавил: "и нетороглгиво".

(Зачитывает п. 11-12)

"11. Демобилизовать из рядов Красной Армии, действуюгцей на украинском и белорусском фронтах, в распоряжение Украинской партийной организации 1.000 коммунистов и 500 комсомольцев и в распоряжение Белорусской партийной организации 800 коммунистов и 400 комсомольцев для исполіьзования на партийной, комсомольской и другой работе на территории Западной Украины и Западной Белоруссии.

12. Обязать КІЦ КIТ(б) Украины мобилизовать для партийной и комсомольской работы в Западной Украине не менее 2.000 коммунистов и комсомольцев, и ІК КІІ(б) Белорусси для работы в Западной Белоруссии не менее 1.500 коммунистов и комсомольцев, главным образом, украинцев и белоруссов".

IІо п. 12 - Сейчас у нас уже идет иирокий отбор и товарици поедут.

(Зачитывает п. 13)

"13. Обязать ЦК KII(б) Украины и ЦК KII(б) Белоруссии назначить уполномоченных на каждое воеводство по вопросам организации партийной работы. ІІредложить ЦК KII(б)У и ІЦK KII(б)Б в двухдневный срок представить кандидатуры уполіномоченных на утверждение ІЦК BKII(б)".

По п. 13 - Уполномоченный по организации партийой работы будет не один, он будет иметь у себя аппарат и будет руководить вопросами о организации партийной работы. Эти полтторы тысачи, которые мы мобилизуем и Ііолторы тысячи, которые мы получим 
из армии - они пойдут в распоряжение уполюномоченных по партийной работе. Первым краеугольным камнем их деятельности - это выборы, чтобы начать уже организацию работы по гминам и т.д., чтобы можно былю охватить самые низы.

(Зачитывает п. 14-15)

"14. Организовать Временные областные управления, действугшцие на территориах бывших воеводств Западной Украины и Западной Белюрусси, в составе 4-х челювек (два представителя от армейских органов, один от НКВД, один от Временного управления облгастного города).

15. Не люмая пока системы организации профсогозов по професионально-цеховому признаку, как она сушествует в настояццее время, подлерживать инициативу по организации профсогозов на основе объединения всех рабочих данного предприятия. создавая в этих целях фабрично-заводские комитеты".

По П. 15 - Значит делая это потихоньку. Почему не люмая. Они сами сломаготся. как только пойдет создание фабрично-заводских комитетов. Некоторые наши товариши хотели это административно сделать.

(Зачитывает п. 16-18)

"16. Поручить т. Швернику выделить группу профсогозных работников длгя посылики в Западную Украину и в Западную Белюруссию с целью изучения вопросов об условиях труда, о состоянии заработной платы и для оказания помоши в организации профсогозной работы, обязав эту группу все свои предложения согласовывать с ЦК КП(б)У и ЦК КП(б)Б.

17. Назначить от Временных областных управлений комиссаров во все банки на территории Западной Украины и Западной Белорусси, для чего поручить т. Булганину отобрать соответствующее число знаюлцих банковскуго работу людей в трехдневный срок, согласовав их кандидатуры с ЦК КП(б)У и ЦК КП(б)Б.

Для руководства деятельностыо банков обязать т. Булганина выделить временных уполномоченных Госбанка в г. Јьвове и г. Белостоке.

18. Комиссары банков обязаны: а) проверить состояние текуцих счетов и ценностей банков; б) принять меры к открытию и нормальному функционированию банков; в) обеспечить необходимое текушее кредитование промышленных и хозяйственных предприятий.

Считать необходимым повсеместный переход на советскуго валіоту.

Установить, что ни одна банковская операция не может быть произведена без разрешения комиссара банка.

В случае, если тот или иной банк не может быть восстановлен для нормального функционирования, передать его операции другим банкам".

По п. 18 - По банкам это обязательно нужо, пусть специалисты приедут, а то начнутся всякие эмиссии смешивать с иностранными и т.д. Конечно, мы понимаем, но делать ничего не можем, других вопросов много, а нужно разрешить эти вопорсы квалифицированно. Пусть наши партийные специалисты этим делюм займутся.

(Зачитывает п. 19-21)

"19. Операции с иностранными банками пока не производить.

20. Считать целесообразным выдачу денег по вкладам частных лииц не свыше 300 рублей в месяц с разрешения комиссаров банков.

21. Принять меры к немедленному открытыо сберегательных касс. Выдачу денег по вкладам в сберегательные кассы установить в размере не более 300 рублей в месяц".

В отношении денег, это не значит, что вы придете и скажете, не принн- мать злоты. Это директива банка. Злот как рубль ходит, потом незаметно будет как злют станет меньше и меньше. Он сам по себе отпадет. Это директива банка.

(Зачитывает п. 22-26) 
"22. Предіриятия, владельцы коих сбежали или саботируют их работу, национализируются и Временные управления назначают ушрав ляюших для ведения дел этих предІІриятий.

23. Обязать ЦК КГІ(б)У и ЦК КГІ(б)Б представить в декадный срок в ЦК ВКГІ(б) предложения о порядке национализации крупных предприятий и список предприятий, подлежащих национализации.

24. Обеспечить открытие магазинов, базаров, хлебопекарен и прочих предіриятий піо бытовому обслуживанию населения, и обеспечить их нормальное функционирование.

25. Магазины, оставленные владельцами, передать в распоряжение Временных управлений и открыть в них торговлю силами Временных управлений или рабочих коогеративов.

26. Поручить Наркомторгу СССР совместно с Наркомторгами УССР и БССР развернуть в главных городах Западной Белоруссии и Западной Украины государственные магазины".

В национализации предіриятий вы должны помочь. Там нужно учесть мощность, число рабочих, все что піолагается. Это нужно для того, чтобы составить общий список предіриятий для того, чтобы видеть как нужно потом решать. Вы должны помочь в этом.

В отношении магазинов. Не надо полагаться, что тут появится такая сеть, что вы можете игнорировать частника. Магазины будут появлятся понемногу. Частник пускай пока действует.

(Зачитывает іл. 27)

"27. Установить следуюшие цены: на соль - 20 кол. за килограмм на территории Западной Украины, 30 кол. за килограмм на территории Западной Белгоруссии; на спички - 3 колг. за коробку маленького формата; на керосин - 65 ког. за литр на территории Западной Украины, 66 ког. за литр на территории Западной Белюруссии; на махорку 50 когі. за пгачку 50 грамм".

В отношении товаров. Сейчас уже отпушено Экономсоветом достаточное количество спичек. Они концентрируются близко, 6 тысяч тонн соли, это значит, такое количество, если будет чем солить, значит будет достаточно. Керосина 700 тонн, махорки, сейчас уже концентритуется в Столгцах в таком и таком количестве, на эту коллею переправля ються, и будем реализовывать по городам. Мы принимаем меры, чтобы это развозилось все. Солыо, керосимом и спичками мы также сагитируем население, но эти вещи не только для агитации нужны, они для нормальной жизни нужны.

Как вы это сделаете. Вы долюкны организовать во всех городах сбытовые базы во главе с напиим человеком или местным, но таким челговеком, который в этих делах понимает, чтобы он работал под контролей и пускай отпускает. Есть магазины частные, пускай отпускает. Конечно, мы должны учесть, что сразу из окрестных деревень появя ться крестьяны за спичками, за солью, это віолне пооняно. Мы сейчас не можем организованно бросить всё в деревню, но мы тут должны предусмотреть лимитированный отпуск в одне руки. Это директива, которая пойдет из этого направления к вам. Мы там подумаем и запинем, потому что, конечно, соль будут по два мешка брать и быстро исчезнет. Спекулянты будут появляться. Значит збытовая база, сбытовая контора должны учесть. Значить отпускать ... торговцам поо союзной цене, чтобы он имел малый дефект, потому что торговец за красивые глаза не будет торговать, ему прибыль некоторая нужна, но цены должны быть не выне. Это цены, по котором долюкно покупать население.

(Зачитывает іт. 28-30)

"28. ГІоручить Наркомату Связи (т. ГІересынкину) совместно с СНК Украины и СНК Белоруссии отобрать в двухдневный срок работников Наркомсвязи, в первую очередь 
ıз украинских и белорусских контор Наркомсвязи, для посылки их в Западную Украину и Западную Белоруссию для организации областных и городских Управленцй почтовотелеграфной связи, оформів ни назначение через Военные Советы фронтов.

29. Поручить т. Пересы пкину подобрать в однодневный срок и представить на утверждение ЦК ВКП(б) по одному уполномоченному для Западной Белоруссни и Западной Украины по организации почтово-телеграфной связи на территории Западной Украины и Западной Белоруссии, оформив их назначенге через Военные Советы фронтов.

30. Разрешить оплату корреспонденции как полскими, так и советскими марками.

Обязать т. Пересыпкина отравить самолетом в распоряжение уполномоченных советские почтовые марки, обеспечив их распространение по всем почтово-телеграфным отделениям".

По п. 30 - Вы говорите, что в почтовых нет марок, а у рабочих и крестьян есть марки, пусть они наклеивают. Сколько нужно наклеить на простое письмо, какую марку.

(Голос с места - на территории Западной Белоруссии 25).

Пускай будет 25 копеек.

Между прочим вызвали всех люоей в Москву, и никто не знал, а вызвали канцеляриста, он говорит, что я вам могу не только про Польшу рассказать, но и про весь мир. Никто из ответственных работников не знал, какую марку нужно у нас наклеивать.

(Зачитывает п. 31)

"31. Для обеспечения нужд Временных управлений в автомашинах как легковых, так и грузовых, поручить ЦК КП(б) Украины и ЦК КП(б) Белоруссии определить потребное количество машин, а Военным Советам фронтов выделить это количество машин из числга трофейных".

По п. 31 -

КОВАЛЕВ. - Кое что дали, но поступает пока медленно.

ПОНОМАРЕНКО. - На такой редакции мы настояли. Другие товарици настоивали на другой редакции - просто предложить военным советам категорически здать временным управлениям все машины, являюшиеся сверхштатными. Оказывается это значить, что нужно было бы добавить (смех). Потом согласились, чтобы определить необходимое количество и затем в независимости от штатных и нештатных выделить это количество. Мы сами, между прочим прошляпили. У вас любой лейтенант тацил машины, а вы думали, что так должно быть.

(Зачитывает п. 32)

"32. Поручить т.т. Берия я Мехлису в трехдневный срок представить предложения по вопросом о военнопленных и беженцах".

По п. 32 - По вопросу военнопленных вопрос разрешен. Директива ест. Белоруссы и украинцы солдаты идут по домам, пускай землю делят, а в отношении тех, которые там, нужно их пока что продержать, может быть кое-какие переговоры будут.

(Зачитывает п. 33)

"33. Предложить Наркоминделу ликвидировать иностранные консульства, находяциеся в горадах Загадной Укранны и Западной Белоруссин".

Это решение ЦК исчерпывает все волросы, которые сейчас имегот основное и главное значение. Сейчас все дело в организации. Организация, организация и организация. Јюди и организация.

Сейчас нужно бросить все силь. Самое главное и прежде всего в деле по,дготовки к выборам - это организация округов. Как только прочтете обращение Белостокского Временного Управления, надо гровести митинги собрании, поддержать это дело в газетах, всіоду политработники должны распечатать это обращение, вообце вокруг зтого дела развернуть большевистский огонь агитацин. 
И командируйте по его просьбе представителей в Комитет по организации выборов. Только не все командируйте, а то много будет. Мы скажем. кого командировать. Это будет Комитет. Комитет сейчас же объявит полюжъение о выборах. Разработанное, подготовленное положъение оно будет быстро отпечатано в необходимом количестве экземпляров и разослано вам для того чтобы руководствоваться.

Затем, вы сейчас не должны дать все соображения, кто сидит в поветах, в областях, в городах - нужно чтобы товарищи все дали свои соображения в округа, потому что все данные о населении есть за 1931 г. Сейчас вы точнее знаете что там есть.

(С места - нет).

Как нет?

(С места - это трудно выяснить).

У нас есть справки, а там где нет справок, там по облюжениям, в обшем есть масса источников но которым нужно получить эти данные.

(ЖИТКОВ - (с места). На первой странице бюджета 1939 г. количество населения).

Вот тов. Житков говорит, что на 1-й странице 1939 г. количество населения. В крайнем случае возьмем по 1931 г. Поговорите с городской головой, если он у вас сохранился.

(Голоса с места - нет).

(Голоса с места - есть списки округов).

Там избиратели не все. Он на сейчас на улице где нибудь есть, все равно можно поговорить.

Вобшем определите количество населения и разбейте все на избирательные округа, с таким расчетом, что когда вы получите полгжение в каждой области, чтобы уже были разбиты области на избирательные округа и города.

Кроме того, к этому времени в 10-дневный срок должны быть представлены соображения о национализации промышленности.

Что мы требуем на соображения? Просто дайте список предприятий.

Обрашение мы поможем областному Временному управлению Белостока написать, оно у нас уже сформулировано. Мы считаем, что председателем Областного управления должен быть товариш, который в областном городе сидел, у него есть опыт, а на городское управление посадить одного из товарицей, который.совместно с ним работал, так например если Гайсин будет в Областном управлении Белостока, значит Гершман илии кто либо другой, который там работал; вместе с ним, должен быть в городском управленин.

1)... весь резерв, который сушествует на тй части Белоруссии, которую отдали немцем, как например Беляев и др...

(Голоса с мест - не удержали власти. Смех).

... он будет нами распределен. Многие товарищи пойдут на партийную работу - к уполномоченным по организации партийной работы.

Еще один вопрос попурно. В ЦК ВКП(б) поднимался вопрос об отделах при управлгениях, мне просто не лговко было, что я этот вопрос поставил. Меня спросили, разве весь этот вопрос мучает? Само собой разумеется, что раз сушествует областное в городское управление - оно должно иметь буквально все отделы. Какие это отделы. Нужно использовать те отделы, которые были в управлении, ненужных не заводить, необходимые добавить, добавить например отдел культпросвотительной работы, земельный отделт. У них уже был; отдел аграрный. Нужно эти отделы организовать с некоторыми изменениями. В воеводствах сидело большенство фашистов, но некоторых циновников все жке можно использовать, и организовать отделы. Некоторые товариши поступают очень плохо, сами парятся, а им по 15-20 коммунистов послали, а он все сам утопает, сам паритась и толку нет. Коммунисты эти могут работать самостоятельно. Надо приставить наших товарицей к делу. Это будет ужастно, если мы дадим большое 
количество люодей, а вы - наши руководители - не приставите их к делу, они будут болтаться без дела, такое положение будет непонятно. В некоторых больших городах это дело было и продолюкает и сейчас.

Есть еще целый ряд ошибок и целый ряд положительных явлений. Ну, вот, вознито такой вопрос - есть безработные везде, товариши наши вопят, что делать с безработными. Что сделали в БрестЈитовске? Там было большое количество воронок от снарядов, как только приехал Карасев туда, так он сразу же занялся этим делом, организовал людей за соответствугшуг оплату на засыпку этих воронок. А в Барановичах так до сих пор проехать нельзя, все разрыто у радиостанции. Сожжеты мосты, почему между Брест-Јиитовском и Копляным все мосты восстановливаготся, и я уверен, что эти мосты уже исправлены, это было видно уже тогда, когда я проезжал, в целом ряде мест нет этого дела. Транспорт недостаточно организовывается в городах, в больших в особенности. Нет достаточной инициативы. Есть предняя инициатива, деклгарирование всякое. Вот в одном из городов товариш решил сделать сразу большое делг, он аннулировал преподавание в школе на том языке, на каком было и когда пришли заниматься * ни програмы, ни учебников. Он звонит тогда в Минск, сам безвыходное положение создал, а потом вопит. ІІринимаготся все меры чтобы отпечатать учебники, собрать, чтобы учителями обеспечить и постепенно к этому делу переходить. Добился он первода на белорусский язык, а потом вопит, что учебников нет. Еще были такие ошибки, которые нужно посмотреть чтобы в дальнейшем они не были.

Когда вы уезжали я буквально формулировал первых четыре пункта постановлени, но некоторые товарищи игнорировали эти указания, приехал на место и можно не считаться с порученными указаниями, и сразу же объявляет, что сего числа приступил к выполнению обязанностей председателя Временного управления, предположым тут, а другие товарищи не объявлены, хотя они уже подобраны. Или указания о земле, земля, крестьянский вопрос - это самые сложные вопросы сейчас. Сейчас какая задача? Подня ть крестьян, чтобы делили землго помещичыо, были им морду во всіо, а народные собрания одобрят. Декларации не нужны, мы действием, советом направим.

Некоторые товарищи, как например в Вильно, они поступили на-оборот. Как только приехали - объявили, что отныне вся земля принадлежашая тем-то и тем-то - принадлежит народу. Ишь, декрет недали. В такое положение поставили крестьянство - нам власть разрешила. Это самая крупная политическая ошибка, которая была допушена, допушена в Вильно. Кроме того, в ЦК ВКГІ(б), когда обсуждали вопрос какуго землго делить, считали нужным пропустить церковнуго земліо, это земли небольшие. Наши товарищи обошли это постановление. Речь пшла о монастерских землях, а не о церковных землях..."

Если вы хотите там в бывшей церкви поместить, если вы хотите, то поставьте этот вопрос перед ЦК, а не занимайтесь этим сами. Или некоторые начинагот сразу политику такуго, в отнопении к товарищам, там чуть что не запевелились быстро, не открыл во время, его тянут. В этих вопросах поступать нужно так, не открывает, национализируйте, а если он нарушает попрубуйте на него наложить и 300 злотых. Если после этого не повернется, тогда надо забрать преприятие. Это вот замечания по этим вопросом, которые у нас были. Основное это самая реализация этих решений по вопросу о выборах в эти самые народные собрания. Надо товаришш подойти к вопросу так, чтобы выбирали ліодей хороших. Имейте ввиду, что центр тяжести будет лежать в том, чтобы нужно договориться совместно в отнопении кандидатуры, в отнопении кандидата. Проверить того, кого надо. Умейте отстоять кандидатуры. Имейте ввиду, здесь не такое положение как у нас. У нас народная масса за партией пойдет, у нас нерушимый блок беспартийных и коммунистов. Здесь вы выбираете уполнномоченных, доверенных и там драка такая появится, что он скажет, почему нашего кандидата снимаете и несколько не поймет вапиих указаний. Тут надо это дело политически обеспечить. 
Ясно, что с вами со всеми бу,дут считаться, но мы не испытали как дело будет когда пой,дет избирателыная борьба. Это дело надо посмотреть. Опыта у нас нет. Надо быть осторожнее. Все ППС, бундовцы пойдут. Бундовцев прямо не разрешать, руководителей их надо аресговать, руководителей бундовцев, руководителей ППС.

Госмотрите кто такие какие члены Комитета, может быть так какие нибудь кооптированные рабочие, нужно оставить, а руководителей обязательно нужно ликвидироват.

Нужни ипраиить особое внимание на подготовку к Выборам. Голосование будет тайное.

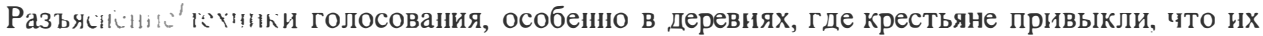
хлестали. Туı надо разъяснить. Тут нужно принять во внимание - может быть остатки кулачесгва, осадников есть. Ведь есть такие места, где приходили ходатайствовать крестья не за помеццика. Все это нужно учесть. Конечно, политики они не изменят, но они могут нам напортить. Нужно выдержки болыне. Самое главное рассказать, чтобы вы работали со спокойной с болышевитской выдержкой, работали с сознанием своей силы, спокойно и уверенно, это для народа ценно.

Предупредите товарицей от левацких загибов, которые попытаются нажать сразу, не считаясь с населением. Мы имеем случан, когода товарищи пытались сделать по подобию нанему, то что мы сделали за 20 лет. Все это будет сделано, тут 20 лет не будем делать, но какой-то срок нужен. ІІре,дупредите всех товарицей, которые приедут к вам, а приедет 3 тысяч человек, особенно из Москвы. Учтите, может быть товарици не проинструктированные.

Вот такой пример, ко мне приехал один и говорит, я побывал на собрании и уже там создали колхоз. Ну как, а у нас еше не создали. Он говорит да, я уже создал. Всем расска)ките, к созданию колхозов не призывайте и колгозов не стройте.

О,днако, крестьянство интересуется, как у вас колхозы. ІІожалуйста рассказывайте им, а то у нас некоторые товарищи поняли, что раз так вопрос ставится, он говорит, как же я расскажу нашн успехи колгхозов, это есть призыв. Это неправильно. ЈІоди спрапивают о наших колхозах, о наней жизни, надо рассказать, но если лю.ди начали организовывать, не препятствуйте. Мы не организовываем пока колхозов.

Вот этим товаришам вы расскажите. ІІриедут коммунисты из Москвы, начальники контор, приедут и начнут организовывать колгхозы. Этот человек активный, но не знаюІций, что мы этой политики придерживаемся. ІІридет время.

Ну, пожалуй, все.

KOBAJIEB. - У кого есть вопросы.

С места: Есть осадники, есть один осадник у которого 120 десятии земли.

С места: Есть разные осадники, некоторые имеют по 10-15 лет.

КОВАЛЕВ. - В отнопении осадников я считаю так. Кто считался осадником. Осадники это бывше легионеры Гилсудского, начиная с 1914 го,да. Іилсудский провел следушую политику: сделал отчуждения помещичьих земель и за заслуги легионером на,делил их через государственные банки земельными участками, по 15-20 га за счет помегциков. Но это уже поляки, которые дрались за великодержавныю ІІолыну. Но прошло уже 20 лет, часть из них скатилась даже на положение бедняков, некоторые поскупились и выросли в кулаков, но так как они в этом районе являяотся пришлым элементом, некоренными жителями деревии, то их там называют осадниками.

Их нельзя, как некоторые крестьянскюе комитеты считали, что нужно их всех изолировать, а землю и все имуцество передать в распоряжение крестьянских комитетов. Нам кажется, что это былобы неверно. К ним нужно подходить как к крестья нам. Но в зависимости от его настроения, там у вас есть представители НКВД, они будут решать вопрос: нужно его изолировать или нет, а вы к нему по,дходите как к кулаку, середняку и бедняку. 
Нужно учитывать в отношении нашиональьной розни. Мы вынуждены были дать воззвания насчет национальной розни, когда прямо говорили - это жидовская капуста мы должны ее забрать.

ПОНОМАРЕНКО. - Кто говорил.

- Выступил один от имени крестьянского комитета, и эту капусту крестьянский комитет изъял, потому что она еврейская. Тоже самое по отношениіо к полякам. Желгание у белоруссов тут понятно... но тут нельзя допускатя такой болыпой национальной розни, потому что кое-кто прямо собирался всех не-белоруссов выселать. Это будет нелравильно. Мы будем иметь на территории некоторых районов болььшой процент польского населения, в особениости на территории районов Белостока и Брест-ЈІитовска, там возможно польского населения будет от 30 до $40 \%$.

ПОНОМАРЕНКО. - Это Іравилььно, что сказал командуюший. Тут дело так обстоит. Осадники более или менее установившаяся категория. Они с особенности, начиная от Барановичи, в укрелленных районах расіолагают и туда дальце к границе. В отношении этих осадников что нужно сказать - если крестьяне дадут им в мор.ду, мы возражать им не будем, но проневоле мы допускать не будем. Другое дело в отношении тех осадников, которые имея 40-50-60 и больше га земли никогда не работали, жили за счет эксплоатации крестьянского труда, и этих осадников крестьяне потребушат, пускай на здоровье даэт. Ничего пллохого от этого не будет. Крестьяне достаточно натеріелись от этих мерзавцев, но смотрите, чтобы по.д эту категориго не попал какой-нибудь бедняк поляк, чтобы его не приравнять к осаднику, человек сам голодал. Тут нужно предотвратить производ. А такие случаи могут быть, потому что поляки культивироали национальные чувства, поляки ничего не имевши даже, а гонжр имел.

Такой ответ вас удовлетворяет.

С места: Да. И попутно у меня есть такой вогрос - есть две категории осадников: о.дна категория, расположенная в километрах 130 - это Барановичи и Молодечно. Вторая категория - это Волковыск и Белосток. Эта категория за счет помечьих земел получила II 20-30 десятии. Если там крестьяне расправляются с этими осадниками, это не плохо, это правильно, но здесь сейчас создается такое положение - осадники получившие земли от помециков, они сейчас сдерживают крестьянство, сдерживают раздел гоменичьих земел.

ПОНОМАРЕНКО. - Нужно натравить на них крестьян. Обязательно их нужно разобачить, ноказать, почему они сдерживают раз,дел земли и т.д. Обязательно натравить на них крвстьян. ГІусть тоже поошугают.

С места - за Белостоком все города разрушены и требуются в первую очередь не столько соль, не столько спички, сколько требуется стекла и прежде всего, потому что мародерство идет, грабят дома без стекол. В этом нужно крепко помочь.

Следуюший вопрос. За Белостоком не во всех Временных уггравлениях есть типографии, шрифта нет.

ПОНОМАРЕНКО. - Мы создали тройку в составе редакции: редактор, литработник и секретарь. По числу этих троек мы дали шрифт, а вы решили сделать большое количество редакций и разделили по одному. Таким образом шрифта нехватило.

С MECTA - не больше, а меньше, потому что ряд временных управлений не создан.

... а этот вопрос являяется серьезным вогіросом к связи с по,дготовкой к выборам.

ПОНОМАРЕНКО - Дадим шрифты.

- Следуюгций вопрос в смысле взаимоотношений политуправлений армии и Временных управлений. У нас по армии имеется газета для населгения. мы начали уже выггускать, сейчас держим линию чтобы экспедировать в районы нахождения нашей армии, но все же это ІІроходит неорганизованно. Нужна четкость во взаимоотношениях. 
ПОНОМАРЕНКО - О взаимоотношениях, что можно сказать? Они должны быть самые нормальные, не такие как сложились в Гродно.

ЖИТКОВ. - С армией у нас самые нормальные взаимоотношения. Это имелг место с одним командиром, он мне заявил по телефону, что во внимание моего указания ІІринимать не будет.

ПОНОМАРЕНКО. - Что значить во внимание не принимать. Обязательно во всех случаях во внимание принимать. Если это не мотивировано - отказать, а если это правильно - выполнять. Он-же мог сказать, что у меня не было кем бойцы измотались, как крайний выход сделал это ----х ---- нужно обрятиться к нам, мы бы ІІом ---- х ---нимать.

Чем регулируются взаимоотношения? Местное Временное Управление - есть орган военной власти и военный совет армии той, которая диспоцируется, она имеет право направлять работу Временного Управления, имеет право и должен в пределах существующих указаний Военного совета фронта и ЦК ВКП(б). Если председатель Военного Управления хорошо знает эти директивы, так он, если полугает неправильное направление, немедленно сообщит об этом в Военный Совет фронта.

Голос с места: В Августове стекольный заво,д пустили, а денег нет.

ПОНОМАРЕНКО. - Продукциго мы не должны разбазаривать, она дефицитна у нас, и мы должны ее реализовать так, как нужно.

Голос с места: Где будут расселяться беженцы, которые сейчас отходят.

ПОНОМАРЕНКО. - Они будут рассасываться по Западной Белоруссии. Если вы хотите спросить о беженцах, которые у вас осели, так если их много - поставьте вопрос перед командованием, Военным Советом Фронта, чтобы их дислоцировать.

Голос с места: Как в отношении зарплаты.

ПОНОМАРЕНКО. - Я же вам читал постановление ЦК ВКП(б), что это вопрос очень сериозный, что вопрос этот поручен т. Швернику и будет выслана специальная комиссия и вопрос этот будет решаться.

ШУБ. - Города, находяццеся поближе к Минску, полтьзуготься связыо, а дальные городца не имеют связи.

Пономаренко. - В Минск дозваниваготся все и ответы дают им, а сгода в Волковыск недозвонятся и ответа не полугат, члены Военного Совета в разъезде.

ШУУБ. - ГІочему бы не установить радиосеть, чтобы можно было транслировать по ней.

КОВАЛЕВ. - Это будет, но сейчас мы воздерживаемся это делать и закрываем все узлы.

ПОНОМАРЕНКО. - Закрываем передаточную сеть, а у кого есть приемник - пусть работает, пусть принимает Коминтерн и т.д.

Голос с места: в город Волковыск прибыла рабочая гвардия из Сувалок и других городов, как пгоступить с ними.

ПОНОМ̈AРЕНКО. - Я не могу с налетом ответить на такой вопрос. Мы решим как постугить.

Дружинин. - Сейчас части получагот назначение на постоянное местожительства. Нам в гор. Пинск назначается одна из частей, и сейчас эта часть предсатвила Временному Управлению на 200 тысяч рублей ноту, чтобы имеющийся аэродром привести в соответствующий вид.

КОВАЛЕВ. - Вам вероятно предъявлено, чтобы вы обеспечили и рабочой силой и прочвешами, а 200 тысяч у нас есть.

ПОНОМАРЕНКО - Это другое дело.

ДРУЖИНИН. - Мы рабочую силу дали, но ведь это сейчас нужно сделать, там же инжинер нужен, много специалистов требуется.

ПОНОМАРЕНКО - Никаких бюджетов, ассигнований для воинских частей вы не даете. Все средства, которые находятся у вас, они должны идти на нуж,ду гражданского 
управления. Каждая воинская часть имеет свой бюджет на свои нужды, а некоторые товарици воинских частей, они не протир, чтобы более обеспечено у него дело былю, не прочь привлечь источники из других каналов. Этого вы можете не принимать во внимание.

ДРУЖИНИН - С медикаментами у нас глюхо. У нас имеется в наличии заболевания брашным тифом, дизентерией. Я считаю, что этот вогірос нужно пооставить, чтобы он ІІолучил свое разрешение.

КОВАЛЕВ - раненых ІІоляков много?

Дружнин - У нас около 8 тыс. лежит в лазаретах. Своих бойцев мы отправилии.

КОВАЛЕВ - Так у вас в деревнях много раненых.

С МЕСТА - У нас имеются радиоузлы, можно их организовывать?

ПОНОМАРЕНКО - ІІока нет.

С МЕСТА - Можно радиоузел убрать со школы?

ПОНОМАРЕНКО - ІТеренесите в другое место.

КОВАЛЕВ - Нам нужно взять радиоузлы под свой контрольь и учет. Должен до вашего сведения довести, что если начать радиовешание где нибудь, нам трудно разобраться откуда идет радиовешцание из города или из леса, а кое где радиовешание наклевывается . Нам нужно прекратить все радиовешание и до о собого распоряжения командования радио не вводить.

ГАЙСИН - Мы ставим вопрос промышленности в части реализации. Мы можем организовать с тем, цтобы банки кредитовали, промышленность, но помимо вогроса сырья стоит вогірос о вспомогательных материалах. Мы имеем 24 дня, у нас все фабрики и заводы пуццены. Мы можем в бликайшее время очутиться, что у нас увеличится безработнца по городам.

ПОНОМАРЕНКО - Надо будет все что надо для работы промышленности давать. В системе облгастного управления у вас есть отдельная промышленность. Давайте заявку. Куда нужно давать вы знаете. Каналы источников получения сырья и материалов одне, ясно.

ГАЙСИН - Я считал бы целесообразным, чтобы сейчас ІІо линии каждого наркомата в отдельности былга бы организована группа специлистов.

ПОНОМАРЕНКО - Она уже здесь.

ГАЙСИН - Тоже самое я сцитал бы по линии Госплана Белоруссии нужно сделать.

C MECTA - Вопрос с продовольствием у нас налажен, теперь вопрос с товарами. [Іо отдельным городам есть запасы, а у нас нет.

ПОНОМАРЕНКО - Вот оказывается в ГІинске у Дружинина очень много спичек и соли, а в других городах нет.

ЖИЛЯНҢН - В Вильно много осталюсь эстонцев, литовцев и других из разньг государств. Они сейчас буквально осаждают, как можно выехать. Я им ответил. что через неделюдве этот вопрос будет решаться.

ПОНОМАРЕНКО - Что вам можно ответить: граница закрыта, не пускают. Вопрос будет решен.

ЖИЛЯНКН - Вопрос снабжения сельско-хозайственными поруктами в Вильно. У нас хлеба осталось на 6 дней. В деревнях мы весь апгарат подняли на ноги. Сейчас крестья нство продает на польские деньги, они не хо-тят брать этих польских денег, а русских у нас нет. Вот поступило 400 тыс. руб. за это время в банк, но поступило тысяч 50-70 валюютой нашей советской. Это вогрос актуальный.

ПОНОМАРЕНКО - Значит денег вам нужно подбросить.

КОВАЛЕВ - Вы же говорили, что вы посылаете всех. ГІредложите им выехать на месго.

С MECTA - Вопрос о лесе. У нас на месте и я такую установку давал, что крестьяне бедняки могут пользоваться в лесу дровами. В Виленском округе указания поступили, 
что крестьяне могут бесплано брать в лесу сучья, а если лгес, то нужно обрашаться в крестьянский комитет.

ПОНОМАРЕНКО - А вы то думали, это јес государственный, пллату можно установить неболынуг.

1)... сами крестьяне предлагалот, они говорят, что они плгатили за кубометр 7 злотых, теперь, мы думаем, что установим 3,6 злотых. Может быть гораздо меныне этого нужно будет установить іллан, но чтобы был порядок, был отведен лес в порядке санитарной вырубки в известных местах и т.д. Этот вопрос научается и будут даны указания.

С МЕСТА - И второй вопрос о взнимании налогов. Налюги пока не пллатят.

КОВАЛЕВ - Кто не плІатит, крестьяне не плгатят.

С MECTA - Не платят торговцы и зажиточные крестьяне. То, что былов государственном казначействе и в коммунальном банке все разграблено, наличных денег не осталось. Надо платить учителям. ГІрактически этот вопрос еще не решлен. Если мы оставляем в силе хотя бы для важиточной части и торговцев значит мы взнимать налог долгжы. Я хочу піолучить на это ответ.

ГІОНОМАРЕНКО - Будет дан ответ, о пиколе я сейчас не могу говорить, но одно я сно, что с торговцев и промышленности нужно брать налог, если не ясна норма, авансы берите под налог и выдавайте квитанции.

С МЕСТА - Августово переполнено беженцами, можно ли их эвакуировать в отдельные имения. Некоторые говорят, что если их эвакуировать в имения, тогда как же производить раздел земли?

И второй вопорс в части типографии. Шрифт у нас есть, но польский пшрифт, правда преобладает болынинство полььского населения в Августе, но нам нужен белгорусский шрифт.

ПОНОМАРЕНКО - На счет беженцев - вопрос так обстоит: вы должны их зарегистрировать и сообщать сюда точное количество, для того, чтобы мы могли перепланировать в другие места.

На чет шрифта - Запишем и дадим вам белгрусский пाрифт.

С МЕСТА - Как поступать с той лесной продукцией, которую уже крестьяне успели стапцит, взимать пллату или пусть так останется?

ПОНОМАРЕНКО - ГІусть так останется.

С МЕСТА - У меня такой вопрос к командуюгцему - ряд частей взяли продукцию у крестьян, оставили различного рода бумажки, теперь эти крестьяне буквально осаждагот временное управлгение с требованием об уплате за эту продукциго.

КОВАЛЕВ - Имеется строгий приказ, чтобы все расписки выданные крестьянам, заменить на деньги.

ГОЛОС С МЕСТА - Кто это будет делать.

КОВАЛЕВ - Каждая часть знает.

С МЕСТА - Она уплла.

КОВАЛЕВ - Она уже вернулась.

С МЕСТА - Очень много случаев, когда командиры пинут - командир $\mathrm{N}^{0}$-части и подпись неразборчивы.

КОВАЛЕВ - Это было в первый, второй и третий дни. ГІредъявите к 33-й дивизии. У нас были случаи, когда крестьянин пришел и заявил, что у него взяли лошадь, и мы ему лопнадь вернули.

С МЕСТА - У нас эпидемия чумы и рожи сниней. В ветеринарной люеебнице запас сыворстки 300 клгр.

ПОНОМАРЕНКО - Гриехали специалисты, этот вопрос будет решен. В отношении того, чтобы расписки переменили на деньги, нужно установить, кто выдал расписку.

КОВАЛЕВ - Если вы часть не найдете, сообщите, мы уплотим из других средств. 
Крестьянин должен получить стоимость за забранные у него продукты.

С МЕСТА - В Слонимском районе в одной волюсти лежит много жита. Сколько я не ставил вопрос чтобы вывезти этот хлеб, никак не могу добиться.

КОВАJІЕВ - куда мы будем вывозить?

С МЕСТА - это жито находится в одной из бывших волостей за Слонимом.

KOBAJIEB - отправьте в распоряжение временного управления.

IIOHOMAPEHKO - это напрасное беспокойство. Сей час все учитывагот и нужно будет перерасередепить.

С МЕСТА - Когда разбирали имушество помециков, особенно коров, батраки, имея по одной корове, взялии себе еше по одной.

IПОНОМАРЕНКО - Если есть безкоровные, вынесите решение крестьянского комитета, чтобы взять вторую корову и отдать безкоровному.

С МЕСТА - И второй вопорс у меня - во многих помецичьих имениях лежит необломоченный хлеб. Мы, конечно, организуем его обмолютку, но как далыне поступать, куда дать хлеб, кормы и т.д.

IIОНОМАРЕНКО - Сейчас Временные управления возьмут на учет все рессурсы, а потом будут планировать.

С МЕСТА - Все рессурсы на учете крестьянских комитетов.

ПОНОМАРЕНКО - Они возьмут на учет областных управлений, если это не принадлтежит крестьянам, потому что у нас большая армия, болышие города, нам нужо обойтись без того, чтобы туда завозить, чтобы мы имели на учете эти рессурсы и чтобы расходовали не так как кто задумает, а так, как нужно. Если не обмолочено, нужно обмолотить. Крестьянским комитетам нужно призвать и поставить вопорс о том, чтобы обмолотить, причем не так порсто, а за соответствуюшую оплату.

Голос с места: Как быть в крупных местечках нужно организовать комитеты или Временные Управления?

IIОНОМАРЕНКО - Местечковые комитеты организуйте.

Голос с места: В некоторых областных центрах, или в тех городах, где были организованы Временные Управления, сейчас, как вы отвечаете, должны быть организованы местечковые комитеты, как быть.

ПОНОМАРЕНКО - Это речь идет о маленьких местечках. Мы этот вопрос рассмотрим и отзовем товарищей на более серьезнуг работу, чем там.

Голос с места: Я хочу знать - пока что остается связь армии или создается другая свя 3b.

IIОНОМАРЕНКО - Вот сдесь сидит т. Верухин, он должен обеспетать бесперебойнуго гражданскую связь для населения.

Голюс с места: Многие из населения остались без крова, как быть нам, можно ліи использовать монастыри, для размешения этого населения.

КОВАJIEB - У вас мало их, всего один монастырь.

Голос с места: Я хочу договориться на счет одного монастыра, можно ли мне договораться с игуменом в порядке договоренности?

IIOHОМАРЕНКО - Не надо пока трогать монастыри. А для беженцев или для тех, у которых дома разбиты - занимать обшественные здания.

Голос с места: Не хватает.

17ОНОМАРЕНКО - ГІодумайте как сделать. Пусть нанимагот под городом. ЈІодей надо расслелять.

Голос с места: Работу школ мы развернули, учителя работагот, но польское правительство не выплатило им зарплаты, врачам также, а денег мы застали 2.000 злотых.

IПОНОМАРЕНКО - Приедут сейчас банковские работники - разберетесь. Составьте 
бюджет, платить будут.

КОВА.ЛЕВ - Много школ частного порядка и есть хозяева этих школ, они на какихто основаниях вели занятия в школгах до сих пор, а теперь хозаева школт стали в сторону, а там, где во Временном Управлении не разобрались, эти хозяева приходят и говорят давайте дров и т.д. Заставьте их платить.

IПОНОМАРЕНКО - ІПлатить будем. ІІрошло 10 дней, вопрос еще на шее не стоит, пройдет некоторое время и он будет урегулирован. ІІриступите ко взысканию налогов с промышленников. Организуйте школьнуго сеть, чтобы учителя не разбежались, платить будем.

ЖИЛЯНИН - У нас в Вильно есть 4 организации Красного Креста - это фашистские организации. Руководителя одной из этих организаций мы арестовлаи по целому ряду материалов, они набрали других. Эти организации исключительно активны, они помагают офицерам. Мы считаем необходимым собрать их и распустить эти организацин. Там около 1.000 членов.

КОВА.ЛЕВ - ІПусть ІІтеров этим вопросом там занимется.

С МЕСТА - 20-го числа до прихода нашего ППС-овцы выпустили свои деньги и выплатили рабочим.

ПОНОМАРЕНКО - Надо заплатить настоящеми деньгами.

КОВАЛЕВ - Нужно рабочих натравить на свои комитеты.

С МЕСТА - У нас есть сход, пусть крестьяне берут.

ПОНОМАРЕНКО - ІПусть берут, только не по второй корове давать, а бескоровным и люшади давать безлошадным, а если есть хорошие лошади и для конницы годятся, продержите их.

С МЕСТА - Есть фолварки, как с ними поступать.

IIOHОМАРЕНКО - ІПусть крестьяне сами поступают с ними как хотят.

ОБЬЯВЛАЕТСЯ ПЕРЕРИВ.

\section{ПОС.ЛЕ ПЕРЕРЫВА}

IIOHOMAРЕНКО - Для вашего сведения, я вам зачту решение Бюро ЦК о назначении товарищей уполномоченных по вопорсам организации партийной работы, председателей областных временных управлений и председателей городских временных управлений. (Читает)

"7. Утвердить уполномоченными ЦК КІІ(б) Б Белшоруссии по вопросам организации партийной работы: по Белостокскок области - т. Игаева С.С., Виленской области - т. Байкачева Г.М., ІТолесской области - т. Карасева И.Н., Новогрудской области - т. Тур І.П.

ІІоручить отделу кадров ЦК КІІ(б)Б, в однодневный срок, подобрать по три инструктора при каждом Уполномоченном ЦК КІІ(б)Б по организации партийной работы одному техническому работнику.

8. Утвиердить председателями Временных управ.лений областей: Белостокской - тов. Гайсина В.Б., Виленской - тов. Жилянина Я.А., Полесской - тов. Калинина П.З., Новогрудской - тов. Бондаренко П.В.

9. Утвредить председателями Временных Управлений городов: Вильно - тов. Краскова II.Е., Новогрудок - тов. Кузнецова, Белостока - тов. Спасова П.С., ІПинска - тов. Дружинина А.И., Барановичи - тов. Костюка С.С., Во.пковыска - тов. Беляева С.М., Лиды - тов. Семенова Г.И., Брест-Јитовска - тов. Горелика Л.А.

10. Утвердить уполномоченных по организации связи в Западной Белоруссии - тов. Верухина В.Ф."

Все остальные товарищи, которые отошли отгуда, остаются в резерве в нашем распоря жении. Сегодня мы тут сделаем все, что нужно для их работы.

Еще несколько замечаний, по вопросам, которые вас должны интересовать. Во-первых зарплата. Товарищи имеют деньги и ходят голодными, еспи не захватили из Минска. 
Нужно иметь ввиду, что вам положена зарплата, как никак мы с вами кое какую работу проводим. ГІоэтому значит надо и нормально жить, располагаться, а вы пока живете так, как в 1918 г. в занятом городе, который через два дня надо бросать, по 10 челювек в одной комнате, о квартире не думаете. Не полагайтесь на то, что мы через месяц с вами уедем, а тут освобожденные белоруссы займут места. Мы и их привлечем, но нам нужно более длительное время поработать. Значить берите на учет квартиры и располагайте товарищей, которые будут приезжать.

О заработной плате мы тут подумаем и дадим что причитается. Мы посылаем людей в распоряжение временных управлений. Вы говорите, что людей нет, банковских работников, а вы помните как товарищ Свер,цлов подбирал Максима на банк, а вы тут думаете. Тем более мы думаем построить коммунистическую секциго из наших специалистов, а вы подумайте кого куда лучше послать.

ЖИТКОВ - Вы указали, что обязательно в гмины нужно послать кого-нибу,ць.

ПОНОМАРЕНКО - Это другое дело. Этих не надо трогать. Есть отдельные товариіци, которые направлены в ваше распоряжение для использования специально по работе с крестьянскими комитетами. Гускай они этим вопросом и занимаются. Еслиже у вас окажется, что тот или другой товарип какой-нибудь специалист, то вы можете сделать перестановку. Это разрешается, но не сголяйте этот участок работы. Но обя зательно чтобы был работник по работе с крестьянскими комитетами.

О газетах и литературе. Я сам у т. Гайсина в Белостоке видел громадные тюки газет, а население гоняется за газетой. Организуйте киоски. Тов. Верухин, не только телефоннуг связь нужно организовать, а нужно наладить нормальную почтовую связь. Теперь уже такие возможности имеготся, чтобы у нас не получалось так, что если нет самолетов, то газеты не доставляются. Сейчас и в Минске сконилось 300 газет без отправки. Временным Управлением со всей стороны надо организовать,дело так, чтобы бесперебойно розница торговала газетой (через киоски и т.д.).

На этом разрешите совещание председателей Временных Управлений Западной Белоруссии закончить.

Oryginał, maszynopis.

NARB w Mińsku, zesp. 4, spr. 21, t. 1748, k. 1-23.

a) Inicjały stenografistów.

b) Wielkie litery oryginału.

1. Brak w oryginale fragmentu stenogramu. 


\section{Dokument 9}

1939 październik 9, Bialystok - Sprawozdanie radzieckich agitatorów skierowanych do gminy Krypno.

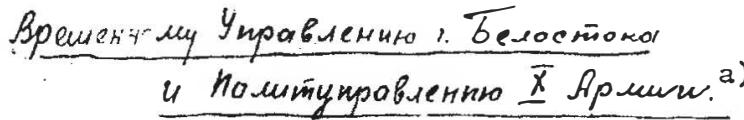

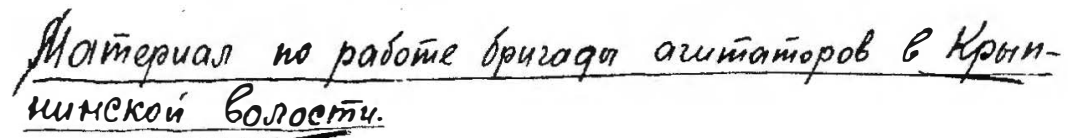

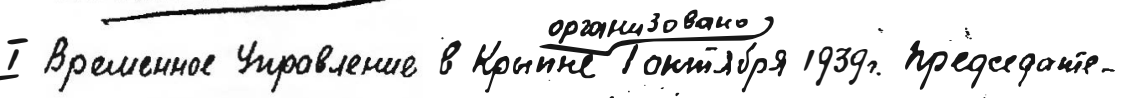

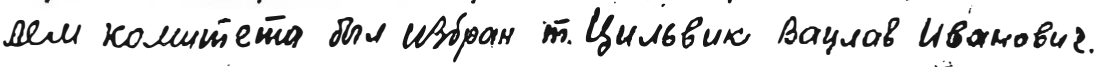

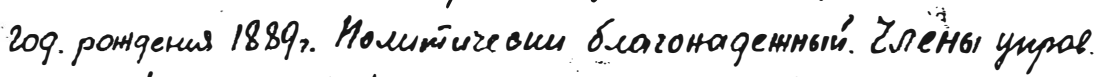

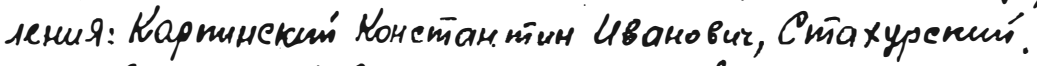
ocun, Jukymickun' Aspecakgp, Kuby Mackoberuí llerñuesab

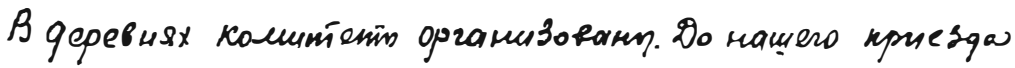

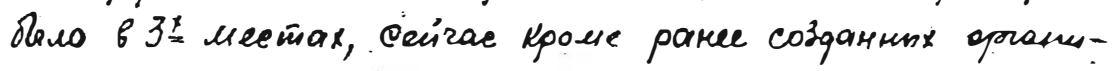

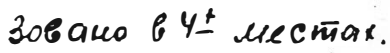

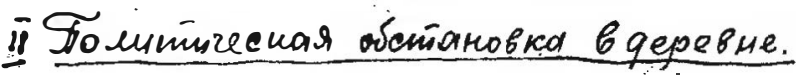

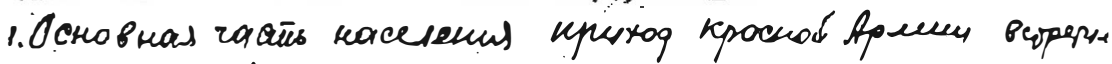

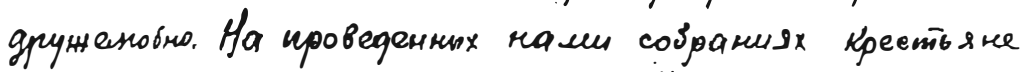

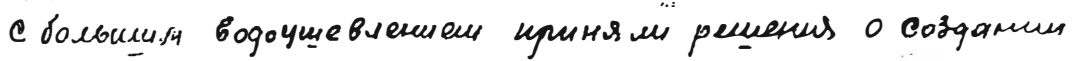

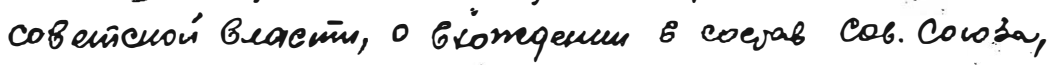

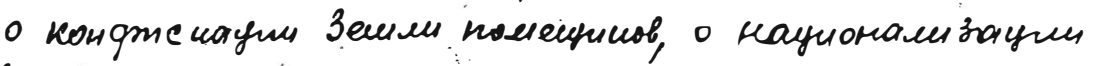
бонсіов, gradpue is 3ahogpb.

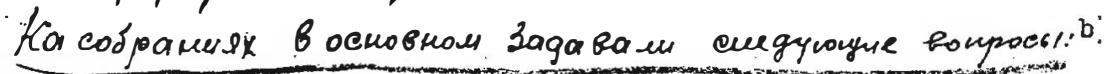
"2obophin, zoo a cop. cocose onsiñ nog ogrum oges co 4 egsin

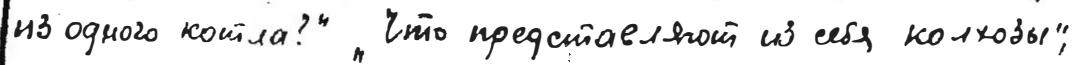

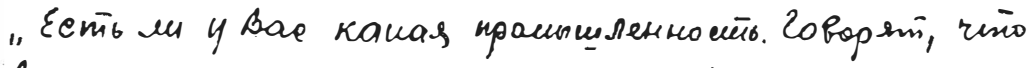

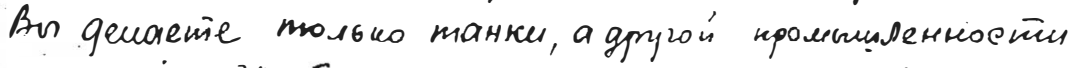

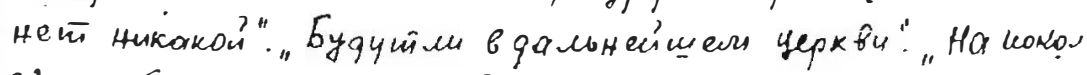

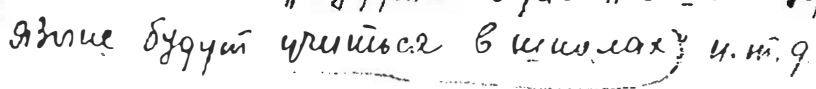




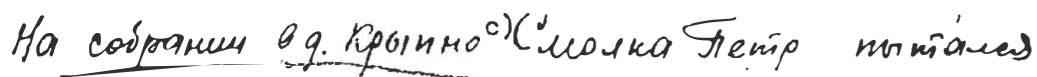
exprobyupobaño racererue. Crazaila of - upequersich

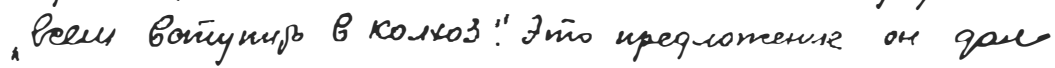

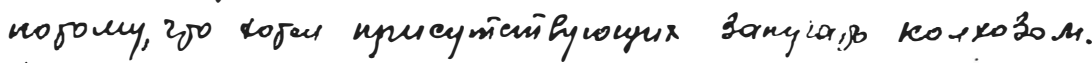

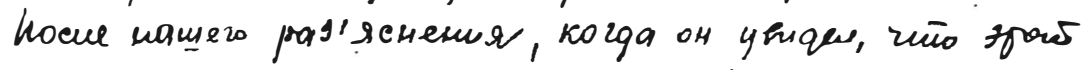

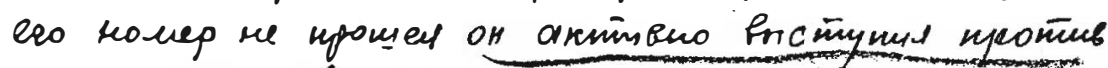

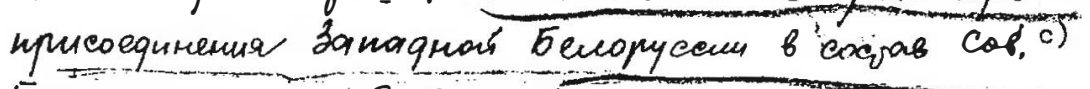

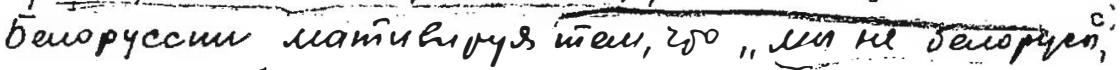

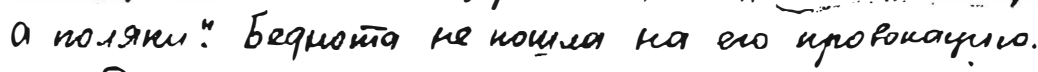

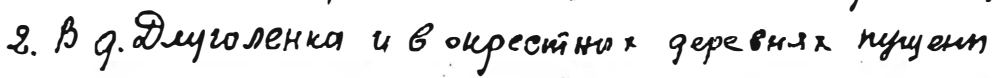

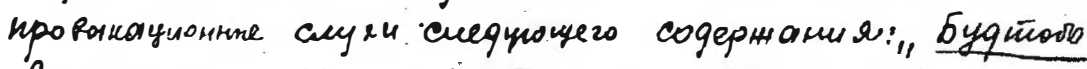

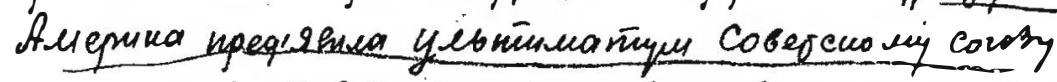

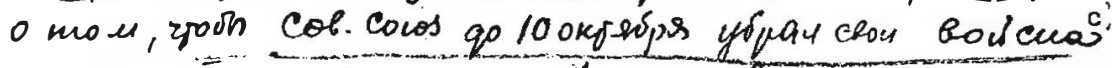

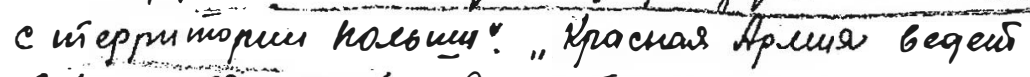

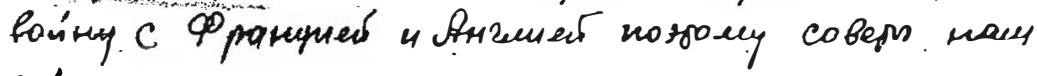

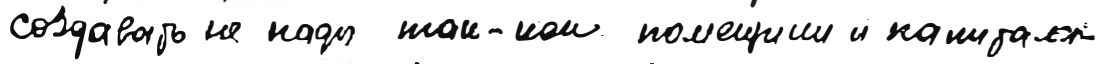

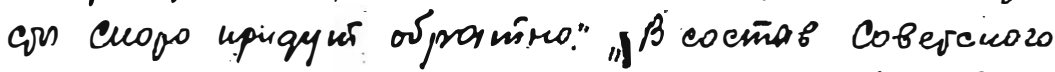

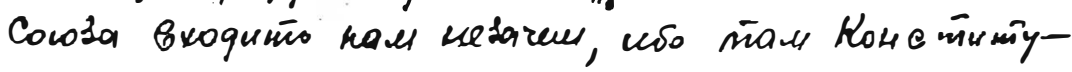
yug he rapogras, a ebpericuas.?

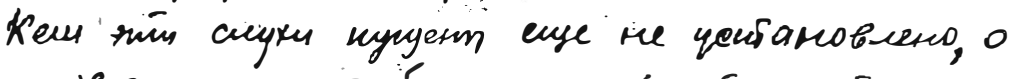

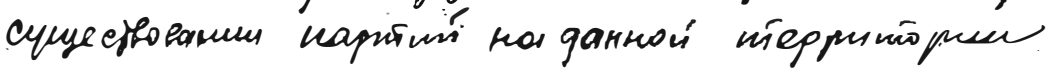
noka ue ufbecuino.

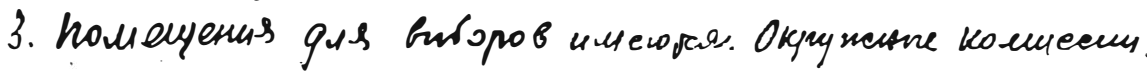

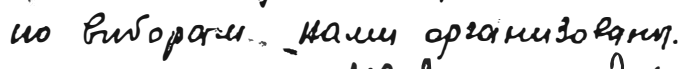

0.10 .391$. UP. Mañinuming. (Nieczytelne 4 poäpisy)

Oryginał, rękopis.

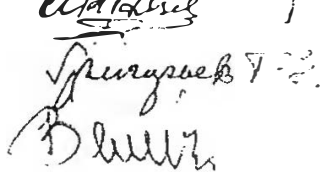

Źródło: PAOSOG w Grodnie, zesp. 6198, spr. 1, t. 5, k. 2a-2b.

a) Podkreślenia oryginału.

b) Podkreślenia w oryginale dokonane w trakcie czytania, na marginesie obok pytań zaznaczono pionową linią.

c) Podkreślenia w oryginale dokonano w trakcie czytania. 


\section{Dokument 10}

1939 październik 12, Mińsk - Apel czlonka rady wojennej frontu i sekretarza $K C K P(b) B P$. K. Ponomarenki do obwodowych pelnomocników ds. pracy partyjnej i przewodniczqcych zarzqdów tymczasowych w sprawie przygotowań do wyborów do Zgromadzenia Ludowego Zachodniej Bialorusi.

\section{ВСЕМ ОБЛАГОСТНЫМ УІІОЛНОМОЧЕННЫМ \\ ПО ВОIІРОСАМ ІПАРТИЙНОЙ РАБОТЫ. \\ ВСЕМ ІТРЕДСЕДАТЕЛЯМ ОБЈАСТНЫХ И ГОРОДСКИХ ВРЕМЕННЫХ УІІРАВЈІЕНИЙ}

Согласно решения Комитета по выборам в Народное Собрание Запа,дной Белоруссии выборы в Народное Собрание назначены на воскресение 22 октября 1939 года.

Комитет по выборам утвеврдиил поря,док выборов в Народное Собрание. Вся избирательная кампания к выборам в Наро,дное Собрание должня прово,диться по,д лозунгами: установления Советской власти на территории Западной Белоруссин, вхождения Западной Белоруссии в состав БССР, одобрения конфискации помецичьих земель, требования национализации банков и крупной промышленности.

Выборы, как это определено поря,цком выборов, производятся на основе всеобццего, прямого и равного избирательного права при тайном голосовании.

ГІраво выставления кан,ди,датов в Депутаты Народного Собрания обеспечивается за крестьянскими комитетами, Временными Управлениями, собраниями рабочих по предприятиям, собраниями рабочей гвардии, собраниями интелигенции. Эти собрания должны выбирать также доверенных лиц, которые затем на окружных совеццаниях доверенных лиц договариваются об обцей кандидатуре по округу.

Выборы имеют колоссальное политическое значение; Наро,дное Собрание будет решать основные вопросы госу,дарственного устройства. Главной задачей командированных дія работы на места коммунистов, армейских политработников и Временных Управлений -является такое политическое руководство выборами в каждом избирателььном округе и в каждом избирательном участке, при котором былю бы обеспечено избрание преданных Советской власти кандидатов, смогуцих отразить действительные интересы наро.да.

Исхо,ця из этого предлагаг:

1. Имея в виду чрезвычайно краткие сроки всех этапов избирательной кампании, немедленно приступить к организации избирательных округов и избирательных участков.

2. Распределить партийные и комскомольские силы так, чтобы каждый избирательный округ и избирательный участок были бы обеспечены нашим влиянием.

3. Начать выдвижение кандидатов в депутаты Народного Собрания, а также выборы доверенных лиц, которые затем на окружном собрании доверенных договариваются об одной кандидатуре.

4. Начать широкую популяризацию задач Народного Собрания, поря,дка организации выборов, широчайшую агитациго под лозунгами избирательной кампании.

5. Армейская печать и вновь созданные газеты сейчас главное внимание должны посвя тить вопросам избирательной кампании, агитации за кандидатов, о которых договариваются доверенные на окружных собраниях доверенных, разьяснения порядка органнзации выборов и т.д.

6. Обратить большое внимание и теперь же на технику избирательной кампании. ГІоря ядок организации выборов печатается в централизованном порядке и уже поступил в областные центры; их немедленно нужно получить на места; нужно заняться по.цбором 
помешений избирательных участков, надлежапим их оборудованием и оформлением, изготовлением урн.

7. День выборов в Народное Собрание должен быть днем всенародного праздника и проведен с болыыним политическим подъемом.

8. Нужно привлеть в качестве агитаторов и членов избирательных комиссий участковых и окружных найболее активных местных товарищей.

В процессе избирательной кампании должен вырасти болыной актив из местных силт, который должен быть изучен, на который можно будет опереться в своей работе и далыне.

9. Обязанностыо политорганов РККА является бросить все партийные и комсомольские силы на обслуживание избирательной кампании в отведенных и закрепленных политорганами за каждой чистью зонах. Поэтому договоритесь немедленно с политорганами о закреплений людей за избирательными участками.

10. Пос.пе образования избирательных участков немедленно приступайте к составлению списков избирателей, привлекая для составления местную интелигенцию: учителей, врачей и т.д., тпцательно их проинструктировав. Избирательные списки составлять целесообразнее всего, путем обхода домов и квартир избирателей.

11. Красная Армия в выборах в Народоне Собрание не участвует.

Кандидатуры руководялцих работников армии и Временных Управлений могут быть выставлены в качестве кандидатов в депутаты. Во избежание выставления и баллотировки в разных округах одних и тех же руководяцих работников армии, просьба в случаях выставления этих кандидатур согласовывать с нами.

12. Предупреждаю об исключительной ответственности перед партией за проведение выборов в Народоное Собрание.

Нужно бросить на это дело все силы, все средства, все ресурсы, не забывая, что эту болыную работу мы должны провести в короткий срок.

Член Военного Совета фронта

Секретарь IЦK KII(б) Бепоруссии

podpis (Пономаренко)

Oryginał, maszynopis

Źródło: PAOSOG w Grodnie, zesp. 6195, spr. 1, t. 15, k. 112-114.

a) Wielkie litery oryginału. 


\section{Dokument 11}

1939, listopad 5, Moskwa - Rozkaz Komisarza Spraw Wewnętrznych ZSRR w sprawie szybkiego oczyszczenia obszarów Zachodniej Ukrainy i Zachodniej Biatorusi od wrogich elementów

Coв. Секретно.

\section{$\underline{\Pi \text { Р К K } 3}$}

\section{НАРОДНОГО КОМИССАРА ВНУТРЕННЫХ ДЕЛ СССР}

\section{Н001353 от "5" октября 1939 года $^{\text {b }}$}

НКВД союзных, автономных республик, Начальникам УНКВД Краев и Областей, Начальникам особых отделов военных окрыгов, Начальникам ДТО, Начальникам 3 Отделов ИТЈ и ИТК, начальникам Управленией и Отделов НКВД СССР

В целях бустрейшего очишения территории Западной Украины и Западной Белоруссии от враждебных элементов прик а 3 ы в а ю:

1. - Выявить проходящих по действугшим и архивным агентурным и следственным материалам участников троцкистских, белоэмигрантских националистических, террористических и других к-р организаций проживагших на территории Западной Украины и Западной Белоруссии.

2. - По этим же материалам выявить секретных агентов иностранных разведок, провокаторов, резидентов, содержателей конспиративных квартір, диверсантов, контрабандистов, работников польских разведывательных и контр-разведывательных органов, жандармерии и полиции.

3. - На перечисленных в п.П. 1 и 2 лиц составить списки по прилагаемой форме и выслать таковые для оперативного использования Наркому Внут-ренных Дел УССР тов. Серову и Наркому Внутренных Дел БССР тов. Цанава.

Об исполнении донести.-

\section{ЗА МЕСТИТЕЈЬ НАРОДНОГО КОМИССАРА ВНУТРЕННЫХ ДЕЈІ СОЮЗА ССР}

(podpis) MEPКУ JIOB

Na górze słowo „Projekt” przekreślone odręcznie

Oryginał, maszynopis

Żródło: Kserokopia oryginału w zbiorach autora.

a) Podkreślenia i wielkie litery oryginału

b) Numer, dzień i miesiąc wypisane odręcznie (w miejsce słowa „październik” wpisanego na maszynie odręcznie wpisano „listopad”). 


\title{
Dokument 12
}

1939 listopad 19, Mińsk - Uchwata Biura KC KP(b)B o organizacji świetlic $i$ domów socjalistycznej kultury w Zachodniej Bialorusi

СТРОГО СЕКРЕТНОа

\section{ЦЕНТРАЛЬНЫЙ КОМИТЕТ КОММУНИСТИЧЕСКОЙ ІПАРТИИ (больневиков) БЕЛОРУССНИ}

\author{
[7 Р О Т O K O Л
}

\section{заседания Бюро ЦК КП(б)Б № 104 П. 8 от 19/XI 1939 г}

\section{Слушали:}

Об организации изб-читателен и домов соцкультуры в западных областях БССР (т.т. Эйдинов, ІІономаренко, Матвеев).

\section{Постановили:}

1. Организовать во всех волостных центрах западных областей БСРР волостные избычитальни, а в уездных городах - дома соцкультуры.

ЦК КІІ(б) Белорусси считает дело организации волостных изб-читален и уездных домов соцкультуры важнейшим политическим мероприятием, имеюшим своей целью усилить партийно - политическое влияние в деревне, закрепить болышее количество коммунистов и комсомольцев, посланных в западные области БССР, на работе в деревне, важнеймим политическим мероприятием, направленным на широкое развертывание массовой воспитательной и культурно - просветительной работы в селах и деревнях западных областей БССР.

2. ІПоручить отделу кадров ЦК КП(б)Б и ЦК ЈЈКСМБ до 15-го декабря 1939 г. подобрать 1000 членов и кандидатов в члены KII(б)Б, а также комсомольцев для работы заведугоними волюстными избами-читальнями и домами соцкультуры.

В целях подготовки товарищей для этой работы, провести с ними трехдневные курсы.

3. ГІредложить Наркомпросу БССР взять с 1 января 1940 г. работников организуемых изб-читален в западных областях БССР на бюджет, избы-цитальни и дома соцкультуры на финансирование.

4. ІІредложить Наркомпросу БССР скомплектовать и направить до 20 декабря сего года для каждой волостной избы-читальну библиотеку в 15.000 книг, для домов соцкультуры - 25.000 книг марксистско-ленинской, научно-популярной, сельскохозяйственной, художественной литературы.

Снабдить волостные избы-читальни и дома соцкультуры комплектами географических карт, портретами, плакатами, картинами, патефонами с набором пластинок к ним, проекционными фонарями и т.д.

5. Обязать Управление Радиофикации с) при СНК БССР до 1 января 1940 года провести в каждой волостной избе-читальне и доме соцкультуры радиоустановку.

6. Предложить Белостокскому, Барановичскому, Вилейскому, Брестскому и Гинскому обкомам КІІ(б)Б и облисполкомам до 15-го декабря с/г подыскать хоропие помешения для организуемых изб-читален и домов соцкультуры.

$$
\text { (podpis Ponomarenki) }
$$


Na dole dokumentu adnotacje odręczne: (do) oddziału propag. i agitacji, organizacyjno-instruktorskiego, oddziału kadr, KC LKZMB, Narkomprosu, Zarządowi radiofikacji przy SNK BSSR, Białostockiemu obkomowi KP(b) B, Baranowickiemu obkomowi KP(b)B, Wilejskiemu obkomowi KP(b)B, Brzeskiemu obkomowi KP(b)B i Pińskiemu obkomowi KP(b)B oraz prostokątna pieczęć kancelaryjna: „Należy zwrócić do sektora Specjalnego KC KP(b)B do 15/XII 39” (data wpisana odręcznie).

Oryginał, maszynopis.

Źródło: NARB w Mińsku, zesp. 4, spr. 3, t. 842, k. 10-10a.

a) Wielkie litery i podkreślenia oryginału.

b) Numery i data wpisane odręcznie.

c) Słowo „Radiofikacja” wpisane odręcznie w miejsce skreślonego „kinofikacja”.

\section{Dokument 13}

1939 listopad 19, Mińsk - Uchwata Biura KC KP(b)B w sprawie organizacji związków zawodowych w Zachodniej Bialorusi.

СТРОГО СЕКРЕТНОа)

\section{ЦЕНТРАЛЬНЫЙ КОМИТЕТ КОММУНИСТИЧЕСКОЙ ІІАРТИИ} (большевиков) БЕЛОРУССИИ

II Р О Т О К О Л

Слушали:

заседания Бюро ЦК КП(б)Б № 104 п. 6 от 19/XI 1939 г.

Об организации профсоюзов в Западной Белоруссии (т.т. Эйдинов, Грекова, ІІономаренко).

\section{Постановили:}

1. ПТровести с 1-го декабря по 1-е января 1940 года выборы фабрично-заводских, местных, цеховых комитетов и групповых профорганов на предприятиях Западной Белорусси, а также выборы районных, городских, областных и дорожных комитетов профсоюзов.

2. Выборы профорганов провести на основе широкой профсоюзной демократии (зактырым тайным голосованием)

Утвердить инструкцию об организапии и проведении выборов профсоюзных органов в Западной Белоруссии (прилагается) ${ }^{11}$.

3. Обязать секретарей оргбюро ЦК КІТ(б)Б по областям утвердить кандидатуры в состав оргбюро по областям и к 25 ноября предсгавить на утверждение ЦК КІТ(б)Б.

4. ІІредложить секретарям оргбюро ЦК КІІ (б)Б по областям, городам и уездам развернуть необходимую работу по проведениго выборов профсоюзных органов в соответствии с настояІцим постановлением ЦК КП (б)Б и решением секретариата 
ВЦСПС от 10 ноября 1939 года.

5. Поручить Оргинструкторкому отделу ЦК КП(б)Б ${ }^{c}$ (тов. Эйдинову) подобрать 3540 товарищей из числа профсоюзных работников, центральных правлгенй профсоюзов и предприятий города Минска и направить их в распоряжение секретарей Оргбюро ЦК КП(б)Б по уездам, сроком на один месяц. для проведения выборов профсоюзных органов и оказания помоци в организацин профсоюзной работы на предприятиях.

6. ІІредложить ЦК ЛКСМБ дать указание уполномоченным ЦК ЈКСМБ по областя м, городам и уездам о включении комсомольских организации в активное участие по организации и проведении выборов профсоюзных органов в Западной Белюруссии.

7. Обязать редакторов республиканских, облгастных и уездных газет широко осветить состояние подготовительной работы и ход выборов профсогозных органов в Западной Белоруссии, организационные принципы и работу профсоюзов СССР.

(podpis Ponomarenki)

Na dole dokumentu odręczny napis „KC WKP(b)”.

Źródło: NARB w Mińsku, zesp. 4, spr. 3, t. 842, k. 8-8a.

a) Duże litery i podkreślenia oryginału.

b) Numery i data pisane odręcznie.

c) Słowa „KC KP(b)B” wpisane odręcznie.

1. Przy protokole brak wymienionych instrukcji.

\section{Dokument 14}

1939 listopad 19, Mińsk - raport Zarzq̨du Milicji BSSR $w$ sprawie mobilizacji kadr do stużby $w$ Zachodniej Biatorusi

COB. CEKPETHO

СЕКРЕТАРЮ ЦК КІІ(б) БЕЗОРУССИИ

тов. ПОНОМАРЕHKO

\section{ДОКЛАДНАЯ ЗАПИСКА}

По представленным нами в ГУРКМ НКВД СССР штатам органов РК Милиции быв. Западной Белоруссии, впредь до утверждения их ІІравительством, разрешено комплектовать Областные и Уездные аппараты РКМ, для чего нами уже направлено из школ и районов БССР - 225 челг.

ІПолностью укомплектовать руководяцим составом и политработниками из числа своих работников мы не сможем, так как по предварительно - утвержденным штатам требуется только руководяцих работников: 


\begin{tabular}{|c|c|c|}
\hline \multicolumn{2}{|c|}{ Зам. Нач. Обл. Управлении по п/р } & - 4 чел. \\
\hline ІІом. Нач. Уездных Отделіов & $\|$ & $-30 "$ \\
\hline Нач. Отделений Обл. Упр. & по п/p & - 8 чел." \\
\hline Пом. Нач.Гор. отделіов & $\mathrm{T}$ & $-1 "$ \\
\hline Пом. Нач. школы & $"$ & -4 \\
\hline Ст. Инструкторов & $"$ & $-38 "$ \\
\hline Инструкторов & $"$ & $-15 "$ \\
\hline IТом. Нач. Гов. Отделений & $"$ & $-34 "$ \\
\hline IПолитруков & $"$ & $-67 "$ \\
\hline
\end{tabular}

201 челा.

ІІоэтому, просьба командировать в органы РК Милиции БССР членов КІІ(б)Б в числе 100 чел. для назначения на указание должности.-

НАЧАЛЬНИК УІІРАВЈІЕНИЯ РК МИЛИЦИИ НКВД БССР

- КАГІИТАН ГОС. БЕЗОГІАСНОСТИ (ГОРДЕЕВ) (podpis)

НАЧАЛЬНИК ІІОЈИИООТДЕЈАА

- СТ. ЛЕНТЕНАНТ МИЛИЦИИ (IIАВЈIOВ) (podpis)

19 ноябра 1939 г. $^{\text {b) }}$

М' ------ г. Минск

Oryginał, maszyпоріs.

Źródło: NARB w Mińsku, zesp. 4, spr. 3, t. 850, k. 268.

a) Wielkie litery i podkreślenia oryginału.

b) Dzień wpisany odręcznie

c) Brak numeru.

\section{Dokument 15}

1939 listopad 20, Mińsk - Uchwata KC KP(b)B zatwierdzająca sklad osobowy biur komitetów miejskich i powiatowych $K P(b) B w$ obwodzie biatostockim.

IIОСТАНОВЈІЕНИЕ ЦК КІІ(б) БЕЈІОРУССКИ

О СОСТАВЕ БЮРО УКОМОВ И ГОРКОМОВ КІІ(б) БЕЛОРУССИ ПО БЕЈІОСТОКСКОЙ, ІІИНСКОЙ, ВИЈЕЙСКОЙ, БАРАНОВИЧСКОЙ И БРЕСТСКОЙ ОБЛАСТЯМ БССРА) 
Утвредить состав бюро укомов в горкомов КП(б)Б.

Белостокская область

По Высоко-Мазовецкому уезду

1. Багуцкий Александр У јьянович

2. Русаков Игнатий Иванович

3. Софейченко Филипп Яковлевич

4. Толкачев Семен Кондратьевич

5. Виноградов Иван Андреевич

6. Немиро Витолььд Иосифович

По Граевскому уезду

1. Кильбин Александр Ануфриевич

2. ІПлатонов Василий Платонович

3. Марковский Лука Корнеевич

4. Шершнев Афанасий Андреевич

5. Решмаков Дмитрий Федорович

\section{По Бельскому уезлу}

1. Мовчанский Дмитрий Степанович

2. Михейчик Василий Фомич

3. Погич ІТавел Сильвестрович ${ }^{\text {b) }}$

4. Рожновский Иван Викентьевич

5. Мануйлов Дмитрий Иванович

6. Певин Нисон Аронович

По Августовскому уезду

1. Авхимович Николгай Ефремович

2. Беленчик Алтександр Михайлович

3. Дементьев Василий Максимович

4. Рымша Александр Кузьмич

5. Жадовский Дмитрий Митрофанович

6. Кулинкович Иосиф Никопаевич

\section{По Гродненскому уезду}

1. Рыжиков Иосиф Иванович

2. Блинов Даниил Ананьевич

3. Яцкевич Савелий Евсеевич

4. ІТошвенчук Иван Максимович

5. Одинцов Михаил Цванович

По гор. Гродно

1. Кульбацкий Иван Яковлевич

2. Масарский Вульф Шлемович

3. Славинский Владимир Иосифович

4. Ротайко Петр Иванович

5. Карпов Николтай Васильевич

6. Булавенко Сергей ІІављювич
- 1-й секретарь укома КІІ(б)Б.

$-2-\breve{и}$

- 3-й

- Председатель уисполкома.

- Нач. Уездного отд. НКВД.

- Редактор уездной газеты.

- 1-й секретарь укома КІІ(б)Б.

$-2-и ̆$

- 3-й

- Председатель уисполкома.

- Нач. Уездного отд. НКВД.

- 1-й секретарь укома КІІ(б)Б.

$-2-и ̆$

- 3-й

- Председатель уисполгома.

- Нач. Уездного отд. НКВД.

- Редактор уездной газеты.

- 1-й секретарь укома КІІ(б)Б.

- 2-й

- 3-й

- Председатель уисполкома.

- Нач. уездного отд. НКВД.

- Редактор уездной газеты.

- 1-й секрегарь укома КІІ(б)Б.

- 2-й

$-3-и ̆$

"

- ІІредседатејь уисполкома.

- Нач. Уездного отд. НКВД.

- 1-й секретарь ГК КІТ(б)Б.

$-2-и ̆$

- 3-й

- Председатель горисполкома.

- Секретарь ГК комсомолга

- Зам нач. уездного отд. НКВД. 
По гор. Белостоку

1. Герпман Гирп Мовпевич

2. Осипов Яков Семенович

3. Новиков Иван Степанович

4. Сенькевич Павел Яковлевич

5. Зубович-Чугаев Петр ГІетрович

6. Ратько Сергей Сергеевич

\section{По Бепостокскому уезлу}

1. Глебов Федор Васильевич

2. Марголин Борис Айзикович

3. Ременчик Тимофей Макарович

4. Доробко Павел Алексеевич

5. Бельченко Сергей Саввич

6. Гайпуунов Федор Захарович

\section{По Волковысскому уезлу}

1. Банцирев Игнатий Акимович

2. Смирнов Михаил Михайлович

3. Павловец Николай Иванович

4. Ермак Алексей Васильевич

5. Гриднев Вячеслав Васильевич

6. Калеко Григорий Федорович

\section{По Сокольскому уезду}

1. Казиловка Петр Кириллович

2. Гончаров Никита Прохорович

3. Аксельрод Макс Яковлевич

4. Грибоедов Николай Чванович

5. Гусев Николай Григорьевич

6. Лазарчик Константин Самуйлович

\section{По Ломжинскому уезду}

1. Анисимов Александр Иванович

2. Ермолицкий Матвей Григорьевич

3. ГІупгков Федор Ананович

4. Данилов Василий Фомич

5. Дмитриев Михаил Николаевич

6. Крестников Евгений Павлович
- 1-й секретарь Геркома КІІ(б)Б.

- 2-й "

- 3-й "

- ГІредседатель горисполкома.

- Нач. горотдела НКВД

- Секретарь горкома комсомола

- 1-й секретарь укома КП(б)Б.

- 2-й

- 3-й

- Предсе.датель уисполкома.

- Зам нач. обл УНКВД.

- Секретарь укома ЈIКСМБ.

- 1-й секретарь укома КІІ(б)Б.

- 2-й

- 3-й

- Председатель уисполкома.

- Нач. уездного отд. НКВД.

- Редактор уездной газеты.

- 1-й секретарь укома КП(б)Б.

$-2-\breve{~}$

- 3-й

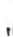

- ІІредседатель уисполкома.

- Нач. уездного отд. НКВД.

- Редактор уездной газеты.

- 1-й секретарь укома КІІ(б)Б.

- 2-й

- 3-й

- Гредседатель уисполкома.

- Нач. уездного от.д. НКВД.

- Редактор уездной газеты.

Na górze dokumentu adnotacja: „B-104/27 z 20/XI.39 r.”oraz ukosem: „Zgoda”, podpisy Ponomarenki i Grekowej. Obok słowo „Projekt” przekreślone.

Oryginał, maszynopis.

Źródło: NARB w Mińsku, zesp. 4, spr. 3, t. 845, k. 34-36.

a) Wielkie litery i podkreślenia oryginału.

b) Słowa „Łogicz Pawieł Silwestrowicz” wpisane odręcznie w miejsce skreślonych „Baskin Grigorij Sołomonowicz". 


\section{Dokument 16}

1939 listopad 29, Minsk - Wyciag z uchwaty KC KP(b)B w sprawie powolania obwodów w Zachodniej Biatorusi oraz obsady wiadz obwodowych.

\section{ЦЕНТРАЛЬНЫЙ КОМИТЕТ КОММУНИСТИчЕСКОЙ ГІАРТИҢІ (боЛЬшевиков) БЕЛОРУССИИ}

No Б-106/b) T.T.

1939 г.

г. Минск

В Ы II HI C K A

из протокола № $106^{\text {b) }}$ заседания Бюро Ц) ЦК КП(б)Б от 29/XI ${ }^{\text {b) }} 1939$ г.

О6 образовании областей: Вилейской. Барановичской, Белостокской, Бретской и Џинской в составе Белорусской ССР.

1. Во изменение решения ЦК КГІ(б)Б от 19.XI-1939 г. образовать в составе Белорусской ССР облгасти:

а) Вилейскую - с областным центром в г. Вилейки в составе: г. Вилейки, Враславского, Вилейского, Дисненского, Молодеченского, Ошмянского (в новых границах) ${ }^{c}$, Поставского, Свенцянского уездов.

б) Барановичскую - с областным центром в г. Барановичи, в составе: г. Барановичи, Барановичского, Волгожинского, Лидского (в новых границах)'), Несвижского, Новогрудского, Слонимского, Столппецкого и Шучинского уездов.

в) Белостокскую - с областным центром в г. Белостоке, в составе: г.г. Белостока, Гродно, Августовского, Белостокского, Бельского, Волюковыского, Высоко-Мазовецкого, Гродненского, Граевского, Ломжинского (в новых границах) ${ }^{\mathbf{c}}$ и Сокольского уездов.

г) Брестскую - с областным центром в г. Бресте, в составе г. Бреста, Брестского, Кобринского и ГІружканского уездов.

д) Пинскую - с областным центром в г. ГІинске, в составе: Г. ГІинска, Косовского, Лунинецкого и части Дрогичинского, Столинского и ГІинского уездов, до границы c CCCP.

2. Утвердить Биюро Обкомов КГІ(б)Б в составе следующих товарищей:

По Вилейской облласти:

КАЛИНИНА ГІетра Захаровича - первый секретарь Обкома КГІ(б)Б, ПЕРОЧИНСКОГО Бориса Хононовича - второй секретарь Обконма КГІ(б)Б, КРАСКОВА ПІетра Евдокимовича - секретарь Обкома КГІ(б)Б по кадрам, ГРУКА ІІавла Федосьевича - секретарь Обкома КГІ(б)Б по пропаганде, КОЗЈІОВА Кирилла Исидоровича - председатель Обисполкома, СОКОЈІОВА Алексея Ивановича - начальник областного управления НКВД, БЕРЕЗА Серафима Федоровича - секретарь Обкома ЛКСМБ. 
По Баранвончской области:

ТУР Ивана ПТетровича - первый секретарь Обкома КП(б)Б, БОНДАРЕНКО Петра Венедиктовича - второй секретарь Обконма КП(б)Б, КАГАНА Наума Исааковича секретарь Обкома КП(б)Б по кадрам, ОСТРОВСКОГО Бориса Хаимовича - секретарь Обкома КП(б)Б по пропаганде, ЖИТКОВА Ивана Кузьмича - председатель Обисполкома, МИСІОРОВА Александра Петровича - начальник областного управления НКВД, ДЕНИСЕВИЧА Федора Яковлевича - секретарь Барановичского горкома КІІ(б)Б, МАСАРСКОГО Исаака Давидовича - секретарь Обкома ЈІКСМБ.

\section{По Бе:лостокской об:ласти:}

ИГАЕВА Семена Степановича - первый секретарь Обкома КІІ(б)Б, КОСТЮКА Самуила Семеновича - второй секретарь Обконма КІІ(б)Б, СПАСОВА Петра Сергеевича - секретарь Обкома КІІ(б)Б по кадрам, СЕМЕНОВА Гавриила Нвановича - секретарь Обкома КІІ(б)Б по пропаганде, МАЛЬЦЕВА Сергея Ивановича - председатель Обисполгкома, ГЈААДОВА Петра Андреевича - начальник облгастного управления НКВД, ГЕРШМАНА Гришу Мовшевича - секретарь Белостокского горкома КІІ(б)Б, ІІЕЧУРЕНКО Владимира Ефимовича - секретарь Обкома ЈІКСМБ.

\section{IІо Бретской области:}

КИСЕЈІЕВА Николая Васильевича - первый секретарь Обкома КІІ(б)Б, ДРУЖИНИНА Александра Ивановича - второй секретарь Обконма КІІ(б)Б, ГОРЕЈИКА Якова Мойсеевича - секретарь Обкома КІІ(б)Б по кадрам, БЕЛЯЕВА Спиридона Марковича секретарь Обкома КІІ(б)Б по пропаганде, ДЈУГАІІІВВСОГО Константина Наумовича - председатель Обисполкома, СЕРГЕЕВА Алексея Андреевича - начальник областного управления НКВД, ІІАСТУХОВА Федора Ивановича - секретарь Брестского горкома KII(б)Б.

\section{ІІо ІІинской области:}

КАРАСЕВА Ивана Никифоровича - первый секретарь Обкома КІІ(б)Б, IIIAПОВАЈIOВА ІІетра Гапеевича - второй секретарь Обконма КІІ(б)Б, ЗАЙІЕВА Никона Кирилловича - секретарь Обкома КІІ(б)Б по кадрам, УЛАЗОВА Ивана Ан.цреевича - секретарь Обкома КІІ(б)Б по пропаганде, МИНЧЕНКО Авксентия Малажовича - председатель Обисполкома, ДУХОВИЧА Сергея Григорьевича - начальник облгстного управления НКВД, ГИМЕЛЬШІТЕЙНА Иосифа Вульфовича - секретарь Пинского горкома КІІ(б)Б.

3. Утвердить областные исполнительные комитеты в составе следуюпци товарищей:

\section{По Барановичской обпасти:}

ЖИТКОВА Ивана Кузьмича - председатель Облисполкома, ТУР Ивана ІІетровича - первый секретарь Обкома КІІ(б)Б, БОНДАРЕНКО ІІетра Венедиктовича - второй секретарь Обкома КІІ(б)Б, МИСЮРОВА Александра ІІетровича - нач. областного управления НКВД, ГЛАДЫШЕВА Ефина Ивановича - председатель Барановичского Уисполкома, АБРАМЕНКО Николая Порфирьевича - зам. председателя Облисполгкома, СЕЈИВАНОВА Адама ІТименовича - зав. ОблЗО, ЯІШКИНА Сергея Ивнаовича - зав. ОблФО, НЕКРЕВИЧА Кондрата Семеновича - председатель крестья нского комитета Ратомской волости, Јицского уезда.

\section{ІІо Белгостокской облгасти:}

МАЈІЬЦЕВА Сергея Ивановича - председатель Облисполкома, ИГАЕВА Семена 
Степановича - первый секретарь Обкома КП(б)Б, КОСТЮКА Самуила Семеновича второй секретарь Обкома КІІ(б)Б, ГЛАДКОВА ІПетра Адреевича - нач. областного управления НКВД. СЕНЬКЕВИЧА Павлга Яковлевича - председатель Белостокского Горисполкома, НИЩИКА Николгая Андреевича - зав. ОблЗО, ЯНКОВСКОГО Ивана Игнатьевича - зав. ОблФО, ІІРҢТИЦКОГО Сергея Иосифовича - зам. председателя Облисполюкома, ДьяЧУК Марию Ивановну - член Облисполюкома, работница суконной ф-ки "Эдельман", г. Белюсток.

\section{IІо Брестской области:}

ДЈУУГАІЕВСКОГО Константина Наумова - председатель Облисполюкома, КИСЕЈЕВА Николая Васильевича - первый секретарь Обкома КІІ(б)Б, ДРУЖИНИНА Александра Ивановича - второй секретарь Обкома КІІ(б)Б, СЕРГЕЕВА Алексея Андреевича - нач. областного управления НКВД, СОЛОВЕЙ Иосифа Менделевича - пред. Брестского Горисполгкома, МОРОЗОВА Якова Наумовича - зав. ОблОНО, РАДКЕВИЧ Раймонта Гвидоновича - зав. ОблЗО, ШАЛМОНА Танхеля Пейлатовича - зав. ОблФО, ФЕДОСЮК Алгессандру Ивановну - член Обисполкома.

\section{ІІо Вилейской области:}

КОЗЛОВА Кирилла Исидоровича - председатель Облисполкома, КАЛИНИНА ІТетра Захаровича - первый секретарь Обкома КІІ(б)Б, ІІЕРОЧИНСКОГО Бориса Хононовича - второй секретарь Обкома КІІ(б)Б, СОКОЈІОВА Алексея Ивановича - нач. областного управления НКВД, СИНЯКОВА Карпа Архиповича - председатель Вилейского Уисполкома, ВОРШІВСКУЮ Добу Борисовну - зав. ОбґОНО, ГОНЧАРЕНКО Артемия Ионовича - зав. ОблЗО, ГОРФУНКЕЛЯ Наума Борисовича - зав. ОблФО. СТОМА Василия Семеновича - член Облисполкома.

\section{ІІо ІІинской области:}

МИНЧЕНКО Ависентия Малаховича - председатель Облисполкома, КАРАСЕВА Ивана Никифоровича - первый секретарь Обкома КІІ(б)Б, ШАГІОВАЛОВА ІТетра Гордеевича - второй секретарь Обкома КІІ(б)Б, ДУХОВИЧА Сергея Григорьевича нач. облуправления НКВД, ХОЛОД Юрия Даниловича - председатель ІПинского Уисполкома, СТАРИКОВИЧА Степана Ильича - зав. ОблОНО, КЛЕЩЕВА Алексея Ефимовича - зав. ОблзО, КОЗЈІОВА Николая Александровича - зав. ОблІФО, БЈІИЗНЮКА Федора Николаевича - член Облисполюкома.

4. ІІросить ЦК ВКІІ(б) утвердить настоящее решение.

\section{СЕКРЕТАРЬ ЦК КІІ(б) БЕЛОРУССИИ}

(IIOHOMAPEHKO)

Kopia, maszynopis.

Źródło: NARB w Mińsku, zesp. 4, spr. 21, t. 1517, k. 5-10.

a) Wielkie litery i podkreślenia oryginału.

b) Wpisane odręcznie.

c) Słowa „w nowych granicach” wpisane odręcznie. 


\section{Dokument 17}

1939 grudzień 1-2, Minsk - Uchwala KC KP(b)B o przedsięwzięciach w zakresie orga-nizacji oświaty ludowej $w$ Zachodniej Biatorusi.

\section{ПОСТАНОВЛЕНИЕ ЦК КГІ(б) БЕЛОРУССИИ \\ О МЕРОПРИЯТИЯХ ПО ОРГАНИЗАЦИИ НАРОДНОГО ОБРАЗОВАНИЯ В ЗАПАДНЫХ ОБЛАСТЯХ Б С С Р а)}

Центральный Комитет КП(б) Белоруссии постановляет:

1. Объявить все школы западных областей БССР государственными и принять их содержание на счет государства.

Ввести на всей территории западных областей Белорусской ССР всеобщее, обязательное, бесплатное образование. В городах - за 7 классов средней школы, на селе - за начальнуго школу.

2. Перестроить систему народного образования во всех школах западных областей БССР и соответствии с советской системой народного образования:

а) ввести совместное обучение учащихся, ликвидировав деление школ на мужские и женские;

б) реорганизовать "повшехные" школы первой ступени - в начальные школы, школы второй и третьей ступени - в неголные средние школы, гимназии и общеобразовательные лицеи - в средние школы;

в) на основании советского законодательства и Конституций СССР и БССР прекратить преподавание религии и исполнение религиозных обрядов во всех школах. Парторганизации при осуществлении этой задачи должны обеспечить глубокую разъя сительнуго работу, исклічагоную всякое а,дминистрирование и грубость, могущю оскорбить чувство верующих.

3. Считать, что основная масса школ в западных областях БССР, должны быть белорусскими.

Переход на белорусские школы не затягивать, однако осуществлять его постепенно, по мере снабжения школ учебниками и квалифицированными преподавателями белоруссами.

Обязать партийные, советские органы и отделы народного образования развернуть пропагандистскую и агитационную работу по ликвидации пренебрежительного отношения к белорусскому языку, прививавшегося правяцими кругами и националистическими элементами в б. Полыше ${ }^{\text {b). }}$

Осудить, неправильные действа некоторых работников отделов народного образования , переводяших школы на белорусский язык без предварительной подготовки. преподавание белорусского языка зачастую поручается польским преподавателям, которые только дискредитируют белорусский язык, и белорусскуго культуры.

4. Ввести изучение русского языка в белорусских школах и шко.пах национальных с 3го класса; изучение белорусского языка в русских школах ввести с 3-го класса, а в школах национальных со 2-го класса.

Горучить Наркомпросу БССР изучить вопрос об организации национальных школ в западных областях БССР и внести отдельным вопросом на рассмотрение ЦК КП(б) Белоруссии.

5. ПЈоручить Наркомпросу БССР объявить дополнительный набор в школы с тем, чтобы охватить всеобщим обучением, в первую очередь, детей рабочих, крестьян и трудя щейся интеллигенции. 
6. Поручить Наркомпросу БССР развернуть сеть школ для взросльх и школ по ликвидации неграмотности и малограмотности для трудяшихся городов и деревень западных областей БССР.

7. Создать с 1-го января 1940 г. педагогические институты в г.г. ІТинске, Белостоке, Барановичах, гродно и педагогические училища в г.г. Белостоке, Гродно, Новогрудке, Бресте, ІТинске и Молодечно, а также два дошкольных педагогических училиша в г.г. Лиде и Волковысске.

8. Поручить Наркомпросу БССР развернуть на территории западных областей Белоруссии сеть детских .домов и ,дошкольных детских учреждений.

Обязать укомы и уисполкомы представлять для этой цели дома бывших фабрикантов, помешиков и другие помещения из муниципализированного фонда.

9. ІІросить СНК СССР и ЦК БКІТ(б):

а) обязать КОГИЗ РСФСР выделить для школ запдных областей БССР 845.000 учебников в соответствии с заявками Наркомпроса БССР;

б) разрешить отпуск 360 тонн печатной бумаги, 111 тонн обложечной бумаги и 107 тысяч метров колгенкора для издания учебников.

10. ІТоручить ЦК ЈІКСМБ и наркомпросу БССР внести в ЦК КІТ(б)Б предложения о соз,дании органов ученического самоуправления.

11. Обязать Наркомпрос БССР в декадный срок внести на утверждение ЦК КІТ(б)Б накдидатуры всех заведующих уездными отделами народного образования.

12. Разрешить Наркомпросу БССР организовать во всех уездных и областных центрах курсовые мероприатия по переподготовке учителей для школ.

(дп)

(podpis Ponomarenki)

$\mathrm{Na}$ górze dokumentu $\mathrm{z}$ lewej strony napisy kancelaryjne:

„B-107/74, z 1-2/XII.39 r.”.

Źródło: NARB w Mińsku, zesp. 4, spr. 3, t. 850, k. 79-81.

a) Wielkie litery oryginału.

b) po tym zdaniu skreślono: „i mające miejsce wśród zacofanej części ludności białoruskiej”. 


\title{
Dokument 18
}

1939 grudzień 1-2, Mińsk - Uchwala Biura KC KP(b)B o przedsięwzięciach w zakresie rolnictwa $w$ zachodnich obwodach BSRR.

\section{СТРОГО СЕКРЕТНО}

\section{ЦЕНТРАЛЬНЫЙ КОМИТЕТ КОММУНИСТИЧЕСКОЙ ПАРТИИ (боЛЫПеВИКОВ) БЕЛОРУССНИ}

\author{
II Р О Т О К О Л \\ заседания Бюро ЦК КП(6)Б № 107 П. 71 от 1-2/XII 1939 Г. ${ }^{\text {b) }}$
}

\section{Слушали:}

О мероприятиях по сельскому хозяйству в западных областях БССР.

\section{Постановили:}

1. Утвердить структуру областых и уездных земельных отделов западных областей БССР, обязав Наркомзем БССР, обкомы КІІ(б) Белоруссии и облисполкомы до 25 декабря с.г. укомплектовать аппараты земельных отделов необходимыми работниками.

Для руководства земельными органами западных областей БССР организовать в Наркомземе БССР специальое зональное Управление во главе с заместителем наркома.

2. Обязать обкомы КІІ(б)Б и облисполкомы закончить молотьбу зерновых культур во всех бывпиих помешичьих имениях до 20 декабря с.г. засыпав все зерно яровых культур исключительно на семена, не допуская их расходования на какие-либо другие цели. Сохранить также на семена весь картофель, имеюцийся в быв. имениях.

Оказать помоцц крестьянам по очистке семенного материала, организуя для этой цели зерноочистительные пункты.

3. ГІредложить Наркомзему и облисполкомам западных областей БССР представить в ЦК КІІ(б) Белоруссии план весеннего сева к 20. XII - 1939 г. с расчетами обеспечения посевных плошадей семенным материалом.

4. ІІередать в ведение Наркомзема БССР все имеюпиеся в западных обла-стях БССР научно-исследовательские учреждения по животноводству и полеводству, предложив Наркомзему БССР до 1-го января 1940 г. определить их задачи и организовать их работу.

5. ГІредложить Наркомзему БССР и облисполкомам западных областей БССР в декабре с.г. провести краткосрочные курсы по переподготовке специалистов сельского хозайства. В течение зимнего периода пропустить через краткосрочные курсы, организуемые в уездах, не менее 5.000 человек крестьян из бедняков-середняков. ГІредложить Наркомзему БССР подготовить свои соображения об организации курсов по подготовке механизаторских кадров, главным образом пІоферов и трактористов для западных областей БССР.

6. Запретить вывоз скота с территории западных областей БССР, предложив Наркомзему и наркомату Совхозов БССР в декадный срок внести в ЦК КІІ(б)Б предложения об организации на территории западных областей конезаводов и племенных животноводческих хозяйств.

ГІоставить вопрос перед Военным Советом БОВО о немедленной передаче воинскими частями племенного поголовья лопадей и другого скота, взятого в бывших помецичьих имениях.

7. Запретить на территории западных областей БССР создание новых хуторов. Обя 
зать обкомы КП(б)Б и исполкомы облтастей оказать необходимую помонц крестьянам, изъявившиим желание сселяться с хуторов в деревни.

8. Обязать Белкоопсоюз (т. Котоводова) до 25 декабря с.г. организовать во всех областях, уездах и волтостях торговлю сельскохозяйственным инвентарем и материалами для нужд сельского хозаяства.

9. Предложить Совнаркому БССР установить на территории западных областей БССР порядок разрешгения спорных земелтных вогросов.

$$
\text { (podpis Ponomarenki) }
$$

Na dole dokumentu napisy: „SNK BSRR, Narkomziemu, Narkomsowchoz, Biełkoopsojuzu, Obkomom KP(b)B (Za Bieł.)"

Obok ukosem prostokątna pieczęć kancelaryjna: „Należy zwrócić do Sektora Specjalnego KC KP(b)B do 15/XII.39" (data wpisana odręcznie).

Oryginał, maszynopis.

Źródło: NARB w Mińsku, zesp. 4, spr. 3, t. 850, k. 76-76a.

a) Wielkie litery i podkreślenia oryginału.

b) Numery i data wpisane odręcznie.

\title{
Dokument 19
}

1939 grudzień 1-2, Mińsk - Uchwala Biura KC KP(b)B powolująca biura komitetów obwodowych LKZMB w zachodnich obwodach BSSR i zatwierdzajaca ich sklad osobowy.

\section{СТРОГО СЕКРЕТНО:}

\section{ЦЕНТРАЛЬНЫЙ КОМИТЕТ КОММУНИСТИЧЕСКОЙ ГІАРТИИ (болЫШеВИКОВ) БЕЈІОРУССИИ}

II P O T O K O JI заседания Бюре IIK КПТ(б)Б № 107 п. 67 от 1-2/XII 1939 г. ${ }^{\text {b) }}$

\author{
Слушали: \\ О персональном составе бюро обкомов ЈІКСМБ \\ в западных облтастях БССР (т. Головкин)
}

\section{Постановијти:}

1. Принять предложкение ЦК ЈІКСМБ о создании бюро обкомов ЛІКСМБ по западным облтастям БССР.

2. Утвердить репाение Бюро ЦК ЈІКСМБ от 11.ЖИ-1939 года о персональном составе бюро обкомов JIКСМБ по западным областям Белоруссии: 
По Барановичской области.

МАСАРСКОГО Исаака Давидовича - первый секретарь обкома ЛКСМБ, НИКОЛАЕНЯ Пафнутия Васильевича - второй секретарь обкома ЛКСМБ, БЕЛЕНЬКОГО Абрама Ароновича - секретарь обкома ЛТСМБ по пропаганде, РЫБАКОВА Александра Кузьмича - зав. отделом пІкольной молодежи и пионеров обкома ЈТКСМБ, АБУГОВА Иосифа Михайловича - зав. оргинструкторским отделом обкома ЈІКСМБ, ЈТБА ЧЕВА Николая Васильевича - уполномоченный ЦК ЈІКСМБ по гор. Барановичи, ТЭЛЬМАХА Ивана Николаевича - начальник опер. отД. НКВД.

\section{По Белостокской области.}

ПЕЧУРЕНКО Владимира Ефимовиа - первый секретарь обкома ЈІКСМБ, ЯСЬКОВА Ивана Емельяновича - второй секретарь обкома ЈТКСМБ, ГРИКО Николая Семеновича - секретарь обкома ЈТКСМБ по пропаганде, КОІІІЕНКОВА Василия Яковлевича - зав. отделом пикольной молодежи и пионеров обкома ЈЛКМСБ, РОЗЕНФЕЈЬДА Абрама Борисовича - пом. начальника политуправления по комсомолу 10 армии, БУТУСОВА Виктора Ивановича - опер. уполномоченный обл. НКВД по пиколам, РАТЬКОВА Сергея Сергеевича - уполномоченный ЦК ЈІКСМБ по гор. Белостоку.

\section{По Брестской области.}

БУГАЕВА Евгения Иосифовича - первый секретарь обкома ЈТКСМБ, НОВИКОВА Василия Тимофеевича - второй секретарь обкома ЈIКСМБ, АЈІЕКСАНДРОВУ Зосю Васильевну - секретарь обкома ЛКСМБ по пропаганде, РЫВКИНА Исаака Борисовича - зав. оргинструкторским отделом обкома ЈТКСМБ, ГРИБАНОВА Федора JІьвовича - пом. нач. политотдела корпуса по комсомолу, ЧЕРНЯКОВА Данила Петровича - уполномоченный ЦК ЈІКСМБ по Брестскому уезду, ПАВЈТОВА Григория Васильевича - уполномоченный ЦК ЈІКСМБ по гор. Бресту.

\section{По Вилейской области.}

БЕРЕЗА Серафима Федоровича - первый секретарь обкома ЈІКСМБ, РУДЕРМАНА Григория Хоновича - второй секретарь обкома ЈІКСМБ, ДМИТРИЕВА Владимира Ивановича - секретарь обкома ЈІКСМБ по пропаганде, ЈIЮТАРЕВИЧА ЈІеонтия Ивановича - зав. оргинструкторским отделом обкома ЈІКСМБ, ХОМЧАНОВСКОГО Сергея Григорьевича - уполномоченный ЦК ЛКСМБ по Вилейскому уезду, НИКОЈІАЕВА Николая Николаевича - зав. отделом кадров обкома ЈІКСМБ. МАЈІИНКОВИЧА Вульфа Бениаминовича - зав. отделом пाкольной молодежи и пионеров обкома ЈТКСМБ.

\section{По Пинской области.}

СЫСОЕВУ Ольгу Александровну - первый секретарь обкома ЈТКСМБ, КРИВОIIЕЕВА Григория Семеновича - второй секретарь обкома ЈІКСМБ, СМЕРКОВИЧА Михаила Николаевича - секретарь обкома ЈЛССБ по пропаганде, РОЗИНА Семена Ильича - зав. отде.лом школьной молодежи и пионеров обкома ЛКСМБ, ЗЫБЛЮКА Ивана Васильевича - уполномоченный ЦК ЈІКСМБ по Пинскому уезду, ГУСЬКОВА Михаила Ивановича - пом. опер. уполномоченного ЭКО Пинского УНКВД, АРОНОВУ Гуту Менделевну - зав. оргинструкторским отделом обкома ЈIКСМБ. (podpis Ponomarenki)

Na dole dokumentu adnotacja: „dla Wydziału Kadr”.

Oryginał, maszynоріs. 
Źródło: NARB w Mińsku, zesp. 4, spr. 3, t. 850, k. 72-72a.

a) Wielkie litery i podkreślenia oryginału.

b) Numery i data wpisane odręcznie.

\title{
Dokument 20
}

1939 grudzień 1-2, Mińsk - Uchwata Biura KC KP(b)B w sprawie wynagrodzeń pracowników zmobilizowanych do pracy w Zachodniej Biatorusi

СТРОГО СЕКРЕТНО:

\section{ЦЕНТРАЈЬНЫЙ КОМИТЕТ КОММУНИСТИЧЕСКОЙ ІІАРТИИ (боЛЬШеВИКОВ) БЕЈОРУССИИ}

\author{
II P O T O K O JI \\ заседания Бюро ЦК КП(б)Б № 107 П. 85 от 1-2/XII $1939 \Gamma^{\text {b) }}$
}

\author{
Слушали: \\ Об оплате товарищам, мобилизованным ЦК КІТ(б)Б \\ для работы в западных областях БССР
}

ІІостановили:

1. Временно до 1 января 1940 года установить следуюшций порядок оплаты товарищам, мобнлизованным дия работы в западных областях БССР до назначения их на должности:

a) работникам: партийного, советского и хозайственного аппарата, рабочим, служацци, в соответствии с существуюшцим законодательством, выглачивать: оклад жалования по месту их прежней работы. Исполкомам выплачивать командировочные (без оплаты квартирных) по месту работы в запа,дных областях БССР.

Распространить настояІций пункт на товарищей демобилизованных по решению ЦК BKII(б) из частей PKKА и направленных на работу в западные области БССР.

б) колхозникам (бригадиры, председатели колххозов и др.) по месту работы в западных областях БССР исполкомы вынлачивают оклады в размере от 350 до 450 руб.;

в) студенты выспих учебных заведений получают стипендию по месту учебы, а испюлкомы выплачивают им от 350 до 450 руб. на месту работы;

г) установить, что выплата производится со дня посылки товарищей на работу в западные области БССР.

2. Товарицам, должности которых определены по месту работы в западных областях БССР установить ставки с 1-го января 1940 г., приравняв последние к ставкам областей восточной Белоруссин.

3. ПТоручить обкомам, укомам КІТ(б)Б, областным и уездным исполкомам до 1 января 1940 года определить на постоянную работу всех товарнщей, командированных в западные области БССР и с 1-го января 1940 г. выплачивать заработную плату только по занимаемой должности. 
Oryginał, maszynopis.

Źródło: NARB w Mińsku, zesp. 4, spr. 3, t. 850, k. 92.

a) Wielkie litery i podkreślenia oryginału.

b) Numery i data wpisane odręcznie.

\title{
Dokument 21
}

1939 grudzień 15 [Moskwa] - Raport Przewodniczącego Związku Pisarzy Radzieckich o pisarzach Zachodniej Bialorusi.

\author{
ЦК КП(б)Б
}

Докладная записка.

\section{O pаботе с писателями западных областей Белоруссий}

В западных областях Белоруссии имеется сейчас около ста писателей - беженцев из б. ІІольши и б. Виленской области. Среди них ряд значительных писателей и литературоведов. Например:

1. ТАНК Максим, молюдой революционный белорусский поэт, нанболее талантливый из всей группы западных писателей. Имеет 5 сборников.

2. ПЕСТРЯК Филипп, б. политзаклоченный, просидевший 11 лет в тюрме, хороший лирик. Сборников не имеет, ибо его не петатали.

3. ТАРАС Нина -- молюдая поэтесса, лирик, имеюццая незаурядное дарование, писала, главным образом, на социальные темы.

4. ЗАСИМ Николай -- молодой белорусский поэт, б. комсомолец, подвергавпийся многократным арестам и пацификациям.

5. ИВЕРС Анатолий -- молюдой белорусский поэт, подвергавпийся арестам и избиеннем.

6. МАШАРА Михась -- белорусский поэт, имеет 5-7 сборников, батрак, писал на социальные темы. По рассказам товарицей из Западной Белоруссии, в последние годы, после ареста и отсидки, попал в лапы хадеков, был некоторые время под их вјиянием.

Из польских писателей значительный интерес представляют:

1. АНЗЕЛЬМ Константин - прозаик, главной темой которого было безвыходное полюжение молодежи в Полыне.

2. БРОНЕВСКАЯ Янина -- талантливая детская писательница, имеет пять книг.

3. СЕЛЬМ Гелена -- детская писательница.

4. Д-ор БОЙЕ Эдвард -- известный критик и литературовед, большой знаток и переводчнк испанской литературы, профессор.

5. МАЗУРЕК Адам -- писатель для юношества.

Все они имеют книги, которые по своему политическому направлению и по художественным качествам, после некоторой очнстки от навязанных цензурой мест, могут быть перепетатаны у нас и представлягот бесспорный интерес для советского читателя.

Из еврейских писателей представляют интерес следующие товарици:

1. КАГАНОВСКИЙ Эфроим -- прозаик, новеллист, имеет ряд книг, крупный, талантливый писатель.

2. ГЕЛЛЕР Бениамин - революционный поэт, имеет 2-3 сборника стихов.

3. ГРОССМАН М. -- романист, имеет два романа -- О Карле Марксе и о Розе 
Люоссемург.

4. РУБИНІІІТЙНН -- поэт, несомненно талантлив.

5. PАIIКИН -- прозаик, получивший премию Переца.

6. МОРГЕНТОЙ -- поэт, рабочий-сапожник, имеет незаурадные творческие возможности.

Обстановка для работы среди этих писателей довольно слюжна. Часть писателей имеет в своей бнографин "темные пятна" (Кагановский был когда-то в Красной Армии, но во время майского наступления ІПилсудского на Киев -- остался в плену и уехал на родину. Часть писателгй по своему происхождению принадлежит к помеццичьему сословиго или офицерству (Анзельм, ІПутрамент и др.). Часть писателей во время своей принадлежности к КІТЗБ и комсомолу бывала и в СССР, сидела в польских тюрмах, выпускалась и вновь арестовывалась. Все эти обстоятельства требуют проверки их политического лица. Мы можем проверить их только по творчеству, в отнопении идейно-художественной направленности их произведений.Но этого мало. Отсутствие детальной проверки несколько мешает разрешению вопроса о печатании их произведений и о посылке товарищей на работу. Стало быть, необходимо ускорить эту проверку или указать Госиздату БССР и редакциям, чтобы отсутствие подобной проверки не служило, непреодолимым препятствием для печатания, а местным органам для принятия на работу. Особо стоит вопрос о близко стояццих к ІІПС, Бунду или бывшиих их членами, а по линии белорусских писателей -- входивпиих в хадецию или санацию (Ильяневич, Гальянш, Левчик).

ІІо всем этим вопросам необходимы соответствуюцие указания ЦК КП(б(Б.

Второй вопрос -- о польских писателях. Их в Белоруссии около 10. Есть случаи переезда из Западной Украины и, таким образом, их количество значительно увеличится . Сейчас они несколько растеряны: им негде печататься. ІІольская газета "Вызволёны Бялысток" -- это только дублировка русской газеты и самостоятельного материала не помешает, -- польского сектора в Белгизе -- нет. ІІрозаики и детские писатели еще могли бы, на худой конец, напечатать свои произведения в переводе на белорусский язык, но поэты лишены и этой возможности.

Польские писатели в Белостоке настойчиво выдвигают три вопроса: о самостоятельной газете на польском языке, о пионерской газете и о радиовеццании на польском языке. Мотивировка всего этого одна: там, где нет нашей советской работы среди людей, не знаюццих русского и белорусского языка (а таких здесь все же много) там враг ведет работу на польском языке, иногда безнаказанно и успешно. Слупание радио из Јондона на польском языке -- распостраненное явление в Белостоке. подрывная работа ведется реакционными педагогами в пюколе. Пионерские издания на русском языке пока недоступны детворе. Учебники на белорусском языке имеются в ограниченном количестве. Bсе это, как будто, оправдывает требование хотя бы временного издания хорошей пионерской газеты на польском языке. Необходима также организация польского сектора в Государственном издательстве БССР.

Третий вопрос -- о еврейских газетах в городах Западной Белоруссии. Сеть их, судя по заявлениям местных работников -- недостаточна. Имеюоцийся в Минске еврейский литературный журнал не справится со всем литературным материалом, ибо основная масса писателей в западных областях Белоруссии -- еврейские писатели. Следует решить вопрос и о еврейских газетах и о дополнительном еврейском литературном журналг.

Четвертый вопрос -- о материальном и бытовом полюжении писателей в Западной Белоруссии. Абсолютное болынинство их бежало из ІІолыни, оставив свое имушесгво, а иногда и рукопоси на произвол судьбы. Околю 46 писателей находятся в общежитии вместе с женами и детьми, в одной болыной и холюдной комнате сплюшыь уставленной кроватя ми (быв. танц-залІ). Мы оказали посильную помоцць наиболее нуждаюгцимся. Для этой 
цели Белосток отпустил около 10 тыс. руб. Союз писатејтей (нап и московский) около 70.000 руб. СНК БССР -- 30.000 руб. Из этих средств около 20.000 руб. уже выдано в качестве единовременной помоши писателям-беженцам. Человек 20-25 устроено на постоя нную работу. Договорено в Белостокским Управлением о выдаче ордеров тем писателям, которые сами находят себе комнаты (таких ордеров на I/XII-39 г. выдано до десяти). Нельзя сказать, чтобы эти мероприятия значительно смягчили нуждаемость писателей и улугшили их положение. Устройство на работу тормозится цввмя причинами: незнанием русского и белорусского языка значительном большинством еврейских писателей и значительной частыо пюлских, отсутствием той квалификации, которая особенно необходима дтя создаваемых газетных аппаратов, эти писатели в большинстве окончили юридические учебные заведения или специально-журналистские, а газетные аппараты, как правило, комплектуются из людей, знакомых с советской газетной работой. Среди писателей много бывших издательских работников, опять таки не могуших приложить свои силы в этой области из-за незнания языков. Правда, писатели соглашаются итти на любую работу и мы устраиваем их на первую попавшуюся. Городской Комитет партии в Белостоке вынес соответствуюшие решение. Проверка исполнения этого решения со стороны ЦЦК КП(б)Б значительно помогла бы Горкому партии, который очень внимательно относітся к писателям, но не всегда может практически продвинуть все вогіросы через аппарат временного управления.

Средства, которыми сейчас располагает Правление Союза, мы предполагаем исілользовать следуюшим образом. Около 20-25 тысяч уйдет на единовременную поомоць, около 25 тысяч уйдет на содержание 15-20 писателей в доме отдыха в Пуховичах, чтобы дать возможность отдохнуть и поправить свое здоровье наиболее измотавінимся товаришам, а также дать возможность тем, кто оканчивает свои произведения ији подготавливает их к печати -- спокойно закончить эту работу: изучение русского языка, семинар молодых писателей, политучебу, приобретение библиотеки, около 10 тыс. на благоустройство общежития, организацию столовки. Остальные уйдут на лечебную помоццмь, на посылку из Москвы и Минска лекторов по вопросам литературы, на помошь в перепечатке рукописей и пр.

Таким образом мы вносим в ЦІК КП(б)Б следующие практические предложкения:

1. Дать соответствуюшие указания партийным органам западных областей Белоруссии об использовании выявленных писателей, печатании их и посылке их на ту или другую работу.

2. Разрешить вопрос о создании польского сектора при Государственном издательстве Белорусской ССР и издании польской детской газеты или ${ }^{\text {b) }}$ соответствуюшего приложения при сушествующей белорусской газете "Піонер Бебарусі", организовать издание польского литературно-художественного журнала.

3. Расширить листаж сушествуюшего еврейского литературно-худо-жественного журнала "ІІІтерн" или организовать издание нового журнала в гор. Белостоке. Необходима также и детская еврейская газета или издание соответствуюгцих приложений при газете "Піонер Бебарусі".

Дать указания облгастным партийным органам об оказании всесторонней помоши -материальной, квартирной и др. -- писателям западных областей.

5. Оказать Союзу советских писателей БССР помольь в отношении перевода в Минск наиболее выявивших себя и талантливых писателей. (Танк, ІІестряки др.)

ПРЕДСЕДАТЕЛЬ ПРАВЛЕНИЯ СОЮЗА

СОВЕТСКИХ ПИСАТЕЛЕЙ

(podpis) (ЈІыньков)

15, XII, $1939^{c)}$ 
Oryginał, maszynopis

Źródło: NARB w Mińsku, zesp. 4, spr. 21, t. 1646, k. $42-47$.

a) Podkreślenie i wielkie litery oryginału.

b) Słowo „kak” zastąpiono słowem „ili” wpisanym odręcznie.

c) Data wpisana odręcznie.

\section{Dokument 22}

1939 grudzień 20, Mińsk - Uchwata KC KP(b)B w sprawie kadr dla rejonów zachodnich obwodów BSRR.

\section{ПОСТАНОВЈІЕНИЕ ЦК КП(Б) БЕЈІОРССИИ О КАДРАХ ДЈІЯ РАЙОНОВ ЗАПАДНЫХ ОБЛАСТЕЙ БССРа)}

$$
\text { от } 20 \text { декабря } 1939 \text { г.') }
$$

1. Обязать отдел кадров ЦК КІТ(б)Б, Минский, Витебский, Могилевский, Гомельский и ІТолесский обкомы КІТ(б)Б к 5. ${ }^{\text {) }}$ І-1940 года подобрать из числа работников обкомов, райкомов и горкомов КП(б(Б, секрегарей и заместителей секрегарей партбюро первичных парторганизации и партийного актива 1600 товарищей для работы в качестве:

1. ІІервых, вторых и третьих секретарей РК КІТ(б)Б

2. Зав. оргинстротделам РК КІТ(б)Б

3. Зав. отделами пропаганды и агитации РК КІІ(б)Б

4. Зам. зав. отделами кадров PК КІТ(б)Б

5. Зав. военными отделгами РК КІІ(б)Б

6. Инструкторов PK КIT(б)Б

7. Инструкторов РК КІІ(б)Б по женработе

8. ІТропагандиство PK КІІ(б)Б

9. Редакторов районных газет

10. Секретарей РК JIKСМБ
300 челт.

" " 110

2. Обязать отдел кадров ЦК КІТ(б)Б и соответс'гвющие наркоматы БССР совместно с обкомами КІТ(б)Б и оргкомитетами ІТрезидиума Верховного Совета БССР по областя м к 5. ${ }^{\circ} \mathrm{I}-1940$ г. подобрать из числа наиболее подготовленных и оправдавіних себя на практической работе $1460^{d)}$ товарищей дия работы в качестве:

ІІредседателей райисполкомов 100

ІІредседателей районных плановых комиссии 100

Председателей райпотребсоюзов 100

Заведуюгцих райфинотделами 110

Заведуюццих райземотделами 110

Заведуюгцих районными отделами народного образованиа 100

Заведуюцих райздравотделами 100

Управляюгци районными отделениями Госбанка 100

Райуполннаркомзагов 100

Районных инспекторов нархозучета $110^{\text {e) }}$

ІТрокуроров районов 100

Народных судей 110 
3. ГІоручить отделу кадров ЦК КІІ(б)Б организовать с 5. ${ }^{\circ}$ I-1940 г. месячные курсы партийных работников на 350 чел. Отделу пропаганды и агитации ЦК КІІ(б)Б разработать учебный план и программы курсов, подобрать высококвалифициронных лекторов и представить на утверждение Біоро ЦК КІІ(б)Б."

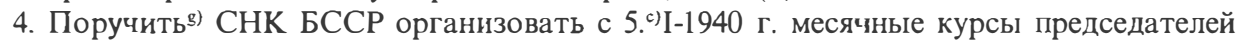
райисполкомов для вновь организуемых районов БССР, согласовав учебный план, программы курсов и лекторов в ЦК КП(б)Б.

5. Обязать СНК БССР и соответствуюшцие наркоматы БССР организовать для

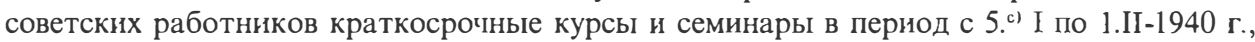
согласовав конкретные сроки и программы курсов и семинаров с ЦК КІІ(б)Б.

6. Обязать ЦК ЈІКСМБ представить Бюро ЦК КІІ(б)Б предложения по вопросу укомплектования РК ЛКСМБ во вновь организуемых районах БССР.

7. Для укомплектования областных и районных партийных аппаратов в западных областях БССР проверенными кадрами машинисток, поручить СНК БССР организовать краткосрочные курсы машинисток на 300 человек. ЦК ЛКСМБ подобрать на эти курсы 300 теловек члеенов ЈІКСМБ.

8. Утвердить количественное распределение отбора работников по областям (приложение) $)^{1)}$.

9. ГІредупредить обкомы и райкомы КІІ(б)Б, что для работы в западных областях должны отбираться наиболее преданные, партийно-выдержанные и наиболее способные товарищи по своим деловым качествам.

(Ponomarenko) podpis

Na górze dokumentu numeracja: „B-III/I 20/XII-39, oraz dekretacja: „Zgoda” i 5 podpisów, m.in. Ponomarenki, Canawy i Grekowej. Z prawej strony słowo: „Projekt” przekreślone.

Oryginał, maszynopis.

Źródło: NARB w Mińsku, zesp. 4, spr. 3, t. 826, k. 1-3.

a) Wielkie litery oryginału.

b) Data wpisana odręcznie.

c) Liczba' „5" wpisana odręcznie.

d) W liczbie 1460 sześćdziesiąt wpisano odręcznie.

e) Poprawiono odręcznie na 110.

f) Po tym zdaniu dopisano odręcznie: „Do 1-I-1940 r.”

g) Skreślono słowo „Zaproponować” i wpisano odręcznie „Polecić”.

1. Por. dokument 23 


\section{Dokument 23}

1939 grudzień 20, Minsk - Rozdzielnik limitów osób skierowanych z obwodów wschodnich do pracy $w$ Zachodniej Biatorusi

Пригожение $\mathrm{H}^{\circ} 1$ к иостановлению

IЦК КІІ(б)Б от 20.XII-39 г.

No $111 / 1$

\section{КОЛИЧЕСТВЕННОЕ РАСІТОРЯЖЕНИЕ ОТОБРАННЫХ РАБОТНИКОВ ПО ОБЛАСТЯМ ${ }^{*}$}

Наименовние долюжностей

Полесская

Секретарь PK KII(б)Б

Зав. оргинстр. отд.

Зав. отд. npon. и агит.

Зав. отд. кадров РК

Зав. военным отд.

Инстр. по женработе

Пропагандистов

Инструкторов РК КІТ(б)Б

Редакторы рай. газет

Председатели РИК-ов

Председ. райкомиссии

ІІредс. Райпотребсоюзов

Зав. Райфо

Зав. Райзо

Зав. Райздрав

Райсекторов

Нархозучета

Райуполнаркомзаги

Райпрокуроров

Нарсудей

Управ. райотд.

Госбанка

Секретарей

PK ЛКЗМБ
Наименование областей

Минская Витебская Могилевская Гомельская

$\begin{array}{rrrrr}85 & 75 & 70 & 55 & 15 \\ 30 & 26 & 24 & 23 & 7 \\ 30 & 25 & 25 & 24 & 6 \\ 30 & 25 & 25 & 24 & 6 \\ 30 & 25 & 25 & 24 & 6 \\ 30 & 25 & 25 & 24 & 6 \\ 30 & 25 & 25 & 24 & 6 \\ 156 & 92 & 87 & 80 & 15 \\ 26 & 23 & 23 & 22 & 6 \\ 26 & 24 & 23 & 21 & 6 \\ 26^{\text {b) }} & 24 & 23 & 21 & 6 \\ 27 & 24 & 23 & 20 & 6 \\ 29 & 26 & 25 & 24 & 6 \\ 29 & 26 & 25 & 24 & 6 \\ 27 & 24 & 23 & 20 & 6 \\ 30^{c)} & 25^{\text {d) }} & 25^{\mathrm{c})} & 24^{\mathrm{n}} & 6 \\ 27 & 24 & 23 & 20 & 6 \\ 27 & 24 & 23 & 20 & 6 \\ 30 & 25 & 25 & 20 & \end{array}$

Oryginał, maszynopis.

Źródło: NARB w Mińsku, zesp. 4, spr. 3, t. 862, k. 7-8.

a) Wielkie litery oryginału.

b) Poprawiono odręcznie z 25 na 26. 

c) Poprawiono odręcznie z 28 na 30.
d) Poprawiono odręcznie z 23 na 25.
e) Poprawiono odręcznie z 22 na 25.
f) Poprawiono odręcznie z 21 na 24.

\section{Dokument 24}

1939 grudzień 28, Mińsk - Informacja specjalna ministra spraw wewnętrznych BSRR o sytuacji w Zachodniej Biatorusi po wycofaniu z obiegu zlotego polskiego.

pIII - 3

COBEPUЕНHO CEKPETHO

СЕКРЕТАРЮ ЦК КІІ(б) БЕЈІОРУССИИ

TOBapишу IIOHOMAPEHKO

\section{СПЕЦСООБЩЕНИЕ}

В связи с опубликованием извещения Народного Коммисериата Финансов Белорусской ССР и Госбанка Союза ССР о переходе на советскуго валготу на территории западных областей Белоруссии, в ряде мест враждебный элемент проводит контрреволіоионное воздействие на отсталые слои населения, распространяя антисоветскуго агитацио и контрреволюционного характера листовки.

В г. Гродно в различых местах, 21-го декабря с г. обнаружены расклеенные листовки контрреволюоционного содержания, написанные на полІьском языке крупным шрифтом под копирку, указанные листовки писаны одним почерком, имегот одинакову форму, возможно, что аналогичные листовки будут обнаружены еще, так как по способу их изготовления можно предполагать, что их написано болыпое количество. Всего за 21-е декабря обнаруљено и из'ято 12 листовок, призывагоцих население к сохранениго польского золотого, как не потерявшего ценности, называя распоряжение Правительства диверсией коммуны и оккупантов.

Наряду с этим, враждебный элгемент проводит антисоветскуг агитацию, призываюшую к восстановлениіо польского государсгва. Владелец ресторана в г. Соколки - КУЛЬКИНА заявила: - "какне-бы мероприятия советская власть не проводила вне, они направлены против нас. Все равно Советская власть у нас продержиться только до весны, а потом снова польское государство будет восстановлено".

Выголняя правительственное решение о переходе на советскую валюту, в ряде мест имелись недостатки и, извращения в работе, так, вопреки правительственным распоря жениям о выплате зарпјаты советскими деньгами, - последняя рабочим и служапим выплачивалась польскими злотыми. В Молодечно с 17 по 19-е декабря, рабочим и служаццим жел. дор. узла выплачено пюольскими злотыми около 200 000, служацци Райзо 7 600 злтотых, работникам Временного управления - 20000 зл. На ст. Соколки при выплате зарплаты, рабочим выдано 3000 злтотых. 
Управление Белостокской желгезной дороги 14-15 декабря полухило 150000 руб. советскими знаками, а рабочим и служашим заработная плғата была выдана полььскими злотыми в связи с чем, ряд рабочих и служаццих совей заработной платой не могли восполььзоваться и проявльлот недовольство.

Некоторые руководители торговых организаций принимали от торговцев польские злоты, для замены их на советские деньги. Так, предселатель Соколььского Горпо ЯРОШЕВ (член KП(б)Б) ${ }^{\text {) }}$, 20/XII - принял для обмена от жены торговша ПРУЖАНСКОГО - польские злоты в сумме 1689 и пытался обменять их в банке, как принадлежащие Горио, к тому-же торговец ПРУ)ЖАНСКИЙ снабженный документами от горгового отдела Горпо, был командирован в г. Белосток дія тойже цели.

Отмеченные недостатки в работе привели к тому, что во многих предприятия и учреждениях осталось большое количчество польжих злотых своевременно не сданых в банк. В г. Белостоке в Горпищеторге осталось 21000 зл., в гвоздильном заводе 10800 зл., Оргбюоро Профсоюзов - 18000 злг. и т.дц.

Несмотря на указанные СНК СССР о замене польских денежных знаков на советские, лицам пполуивгшим зарплату с 11-го декабря, управляюшими облгастями контор Госбанков это распоряжение не выполняется, а некоторые даже не зналот сколько фактически ими выдано польских денег предприятиям и сколько потребуется советских денег, чтобы обеспечить обмен.

НАРОДНЫЙ КОМИССАР ВНУТРЕННЫХ ДЕЛ 'БССР (Л. ЦАНАВА) (podpis)

"28с) декабря, 1939 г.

N $5488 / 9^{\text {c) }}$

гор. Минск

Na górze ukosem odręczna dekretacja: „Rozpatrzyć sprawę Jaroszewa”, nieczytelny podpis Ponomarenki oraz „KC KP/b/B, wpł. nr 3065, 30 grudz. 1939”.

Oryginał, maszynopis.

Źródło: NARB w Mińsku, zesp. 4, spr. 21, t. 1682, k. 265-267.

a) Duże litery i podkreślenia oryginału.

b) Podkreślenie w tekście dokonano odręcznie. Również na obu marginesach akapit ten zaznaczono linią pionową. 


\section{Dokument 25}

1939 (brak daty), Bialystok - Wykaz wydziatów i osób urzędujących w Zarządzie Tymczasowym województwa bialostockiego.

\section{С П и С О K}

\section{ТЕЛЕФОНОВ ОТДЕЛОВ ВРЕМЕННОГО УПРАВЛЕНИЯ БЕЛОСТОКСКОЙ ОБЛАСТИ}

\begin{tabular}{|c|c|c|c|c|}
\hline $\mathrm{N}^{\mathrm{O}}$ & Нағменование отдела & Фамилия начальника & $\mathrm{N}^{\mathrm{O}}$ телефона & $\mathrm{N}^{\mathrm{O}}$ комнаты \\
\hline 1. & Зам لІредседатедя Управ & Каменскиий & 43 & 73 \\
\hline 2. & Адм. Хоз. Отдела & Астановецкий & 30 & 89 \\
\hline 3. & ІІромышленный Отдел & Данилов & 2 & 7 \\
\hline 4. & Торговый Отдел & Гутман & 9 & 101 \\
\hline 5. & Финансовый отдел & ГІрокосенко & 36 & 82 \\
\hline 6. & Топливный отдел & Смоляк & 49 & 62 \\
\hline 7. & Земельный отдел & Можанский & гор. $1-40$ & Сенкевича 67 \\
\hline 8. & Комунальный отдел & Караев & & Варшавская 57 \\
\hline 9. & О'гдел Народного образ. & Яковлев & 40 & 93 \\
\hline 10. & Отдел здравоохранения & Дракин & 42 & 52 \\
\hline 11. & ІІолитпросветотдел & ГІоплавский & 21 & 100 \\
\hline 12. & Отдел труда & Добринский & гор. 3-87 & Ожешковая 5 \\
\hline 13. & Отдел Соц. обеспечения & Микульский & & \\
\hline 14. & Статистич. отдел & Егоров & 12 & 107 \\
\hline 15. & Отдел ннформации & Ринбург & 31 & 33 \\
\hline 16. & Связь & Борискин & 41 & 78 \\
\hline 17. & Уполн. по связи & Верулин & 13 & \\
\hline 18. & Административн. отдел & Герман & & 90 \\
\hline 19. & $\begin{array}{l}\text { Комитет по устройству } \\
\text { беженцев }\end{array}$ & Геллер & 20 & 63 \\
\hline 20. & $\begin{array}{l}\text { Редакциа газеты } \\
\text { "Освобожденный Белосток }\end{array}$ & Зельманов & 47 & 116 \\
\hline 21. & Экспедиция & Ершов & 34 & 28 \\
\hline 22. & ГІономаренко & & KON & мн. 1 (1 этаж) \\
\hline 23. & ІІриемная & & коN & мн. 2 (1 этаж) \\
\hline 24. & Грекова & & 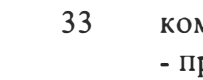 & $\begin{array}{l}\text { мн. } 2 \text { (2 этаж) } \\
\text { риемная }-18^{\text {b) }}\end{array}$ \\
\hline 25. & комут: "Изба Скорбово" & & & \\
\hline 26. & Штаб армии * город & & 99 гор. 8-3 & 3025 (2 этаж) \\
\hline 27. & Инаев & & 39 гор. $8-3$ & 3025 (2 этаж) \\
\hline 28. & Гайсин & & $48 \quad 13-$ & $2815(2$ этаж) \\
\hline 29. & ІІриемная & & $23^{\mathrm{c})}$ & 28 14(2 этаж) \\
\hline 30. & Гласов & & $8-0$ & 13 (1 этаж) \\
\hline 31. & Эйдинов & & $6(1$ & 1 этаж) \\
\hline 32. & Наталевич & & $7(1$ & 1 этаж) \\
\hline
\end{tabular}


33. Ванеев

34. Верухин

35. Гараж

36. Общежитие

37. Родьков (комсорг. ЦК КГІ(б) по белостокской области)

Kopia, maszynopis.

Źródło: NARB w Mińsku, zesp. 4, spr. 5, t. 2113, k. 52-53.

a) Wielkie litery oryginału.

b) Słowa: „prijemnaja-18" wpisane odręcznie.

c) Liczba 23 wpisana odręcznie w miejsce 28 .

\section{Dokument 26}

1939 (brak daty i miejsca) - Wykaz towarów wywiezionych przez wladze radzieckie z Wilna w $1939 r$.

\section{ТОВАРЫ ОТПРАВЛЕННЫЕ ИЗ ВИЛЬНОА}

1. Табачные изделия - 11 вагонов, принадлежавшие быв. ГІольскому государству, - отправленные в адрес:

$\begin{array}{llll}\text { Белосток } & -2 \text { вагона } & \text { - Временн. Управление } \\ \text { Глубокое } & -3 \text { вагона } & - & " \\ \text { Вилейка } & -1 \text { вагон } & - & " \\ \text { Гоставы } & -1 \text { вагон } & - & " \\ \text { Моло,цечно } & -2 \text { вагоны } & - & " \\ \text { Браславль } & -2 \text { вагоны } & - & \end{array}$

2. Бумаги (печатной и оберточной) 15 вагонов (11 вагонов куплено, а 4 вагона взяты из типографий, бежавниих владельцев).

Бумага отправлена в адрес:

1. Минск Союзбумсбыт - 9 вагонов

2. Глубокое Временному Управлению - 4 вагона

3. ГІоставы Временному Управлению - 1 вагон

4. Белосток Временному Управлению - 1 вагон

3. Оборудование связи 12 вагонов (запасы и резервы с почты и телеграфа) - направлено на адрес Барановичи - Времен. Управлен.-

4. Типографское оборудование (печатные мапины, ротации, пирифт). Типографское оборудование принадлежало: 1. Типографни редакции "Русское слово" (хозяин типографии сбежал). 2. Типографии редакции Виленской фапистской газеты (хозяин типографии сбежал). 3. Типографская магистрата. 4. Частная типография Завастовского (Завастовский збежал).-

5. Тигографии "График" (хозяева сбежалии).- 
Типографское оборудование отправлено в Глубокое (имелось ввиду, что Глубокое будет областным центром новой области). 21 октября типографское оборудование переадресовано на Вилейки.-

6. Хлопок - 9 вагонов. Взять на станции Пораны, как безхозайственный не выкупленный хозяевами.-

Хлюлюк отправлен в Белосток - Временному Управлению горо.да;

7. Фанера - 17 вагонов. ІІринадлежала фабриканту Дикту, который сбежал вместе с ІІолььской армией.-

Фанера направлена в Минск - Беллесбыту.-

8. Лен и очесы льна - 26 вагонов (15 вагонов со станции Вилейка, принадлежавшие б. ІПольскому сельхозбанку и 11 вагонов с завода "Электрит".-

Напоравлено в Минск Совнаркому.-

9. Цемент - 15 вагонов. Взять на станции жел. дороги, как безхозяй-ственный. Направлен в Минск Белгосстрою.

10. Фануфактура - 3 вагона. ІТринадлежавшая Торговому дому. Направлено в Минск Наркомторгу.-

11. Фануфактура - 17 вагонов, взяты с 13 олтовых баз, принадлежавших сбежавшим купцам: Жерардно, Янковскому, ІІликаль, Рапопорт, Круше и Ендю, Грошан, ІПознанскому, Айзенберг. Кроме этого закуплено мануфактуры за 169.600 рубл. в магазинах крупных купцов (ІЦупик на 12 тыс. рубл., Блох - на 60 тыс. рубл., Янкелевича - на 34.920 рубл., Зайнгезур - на 12 тыс. рубл., Гуревича на 16.761 рубл., Златина - на 8.167 рубл. и др.). Организацией вывоза, упаковки и погрузки на станции желг. дороги руководил Нач. снаб. Армии тов. Кузнецов по поручению Командиющего Фронтом тов. Кавалева. Вагоны 22 октября были на станции под охраной красноармейцев. С командармом армии тов. Кузнецовым есть до-говоренность о том, что эти 17 вагонов будут отправлены в Минск в адрес Госбанка.-

10.") Футляры для радио-приемников 10 вагонов. Взяты с завода "Электрит".

Направлтены в Минск Наркомместпрому.-

11. Льно - машины / 4 штуки.

5 вагонов взяты с завода "Электрит". Направлены в Минск, Нарком-местпрому.-

12. Молютилкии - 6 штук. Взяты со складов станции желг. дороги, как безхозяйственные товары. Направлены в Минск Наркомторгу.-

14. Асбест - 1 вагон. Взят на станции жел. дороги, как безхозяйственный товар. Направлен в Минск Наркомторгу.-

15. Каучук - 2 вагона. Взят на станции жел. дороги, как безхозяйствен-ный товар. Направлен в Минск наркомторгу.-

16. Минеральное масло - 4 вагона. Взято на станции железн. дороги, как безхозяйственный товар. Направлено в Минск Наркомторгу.-

17. Доски дерева ясень - 1 вагон. Взяты на станции железн. дороги, как безхозя йственный товар. - Направлены в Минск Наркомторгу.-

18. Кожсырье - 2 вагона. Взяты на станции жел. дороги, как безхозяйственный товар. Направлены в Минск, Кожсбыту.-

19. Кожа - 3 вагона. Куплена на частных заводах. направлена в Минск, Кожсбыту.

20. Морская трава - 1 вагон. Взята на станции железн. дороги, как безхозяйственный товар. Направлено в Минск Наркомторгу.-

21. Стальные ленты - 2 вагона. Взяты на складе Сельхозбанка. Направ-лены в Минск, Наркомторгу.-

22. Маслобойные машины - 1 вагон. Взяты на складе Селььхозбанка. Направлены в Минск, Наркомторгу.-

23. Пианино - 7 штук. Взяты на складе жел. дорожной станции, как без-хозяйственные 
товары. Направлены в Минск, Наркомторгу.-

24. Мотоциклы 11 штук - 1 вагон. Взяты на складе Сельхозбанка. На-правлены в Минск, Наркомторгу.-

25. Картон - 3 вагона. Взят на станции железной дороги, как безхозяйственный товар. Направлены в Минск Наркомторгу.-

26. ІІерсть - 1 вагон. Взята на складе Сельхозбанка. Направлена в Минск Наркомторгу.-

27. Грузы рабочой гвар.дии

- 10 вагонов

Автомашины

$-16 "$

Мотоциклов

$-14 "$

Велосипедов

$-28 \quad "$

Радиоприемников

$-16 "$

Фото-обору.дование

- 3 янцика

Мебель разная

- 1 вагон.

Все юти предметы были из'яты у бежавших с Польской Армией крупньх капиталистов и офицеров.-

28. Направлено в Вилейки (Новый областной центр).

Архнв Белорусско-ЛИитовского княжества и некоторые экспонаты ІТушкинского домика (диван, кресло, этажерка Пушкина, несколько его фотографий) - 19 вагонов. Направлено в Минск, Академии Наук.-

29. Архив ГІолицейских и разведывательных органов - 3 вагона направлены в Велейку Уполномоченным НКВД гіо Вилейской области тов. ІТетровым.

30. Архив Воеводства, прокуратуры и суда - 3 вагона направлены особым отделом Армии в г. ІТолоцк.-

31. Архив Просвешения - 1 вагон. Направлен в Вилтейки.

32. Из Вильно-Трокского уез,ца из имения бежавшего помеццика - отправлено 144 бурых лисиц в звероводческое хозяйство Вилейки.-

На все отправленные грузы имеются накладные железной дороги, которые находятся у предсе.дателя Временного Управления города Вильно тов. Краскова.

Грузы отправлялись на станцию и грузились заведуюшими отделов Временного Управления гор. Вильно т.т. Эзриным, Тимошкиным, Бамни, Красковским (типографское оборудование грузилось редактором областной газеты Афенгейном).-

Kopia, maszynopis.

Źródło: PAOSOG w Grodnie, zesp. 6195, spr. 1, t. 230, k. 205-209.

a) Wielkie litery oryginału.

b) Tak w oryginale. Liczby porządkowe 10 i 11 powtarzają się. 